
Food and Agriculture United Nations

Implementing the

Convention on International

Trade in Endangered Species

of Wild Fauna and Flora

(CITES) through national

fisheries legal frameworks:

a study and a guide 

FAO LEGAL GUIDE 4

\section{Implementing the Convention on International Trade in Endangered Species of Wild Fauna and Flora (CITES) through national fisheries legal frameworks: \\ a study and a guide}

Julia N. Nakamura

Blaise Kuemlangan

The Development Law Service, FAO Legal Office 
Required citation:

Nakamura, J.N. and Kuemlangan, B. Implementing the Convention on International Trade in Endangered Species of Wild Fauna and Flora (CITES) through national fisheries legal frameworks: a study and a guide. Legal Guide No. 4. Rome, FAO. https://doi. org/10.4060/cb1906en

The designations employed and the presentation of material in this information product do not imply the expression of any opinion whatsoever on the part of the Food and Agriculture Organization of the United Nations (FAO) concerning the legal or development status of any country, territory, city or area or of its authorities, or concerning the delimitation of its frontiers or boundaries. The mention of specific companies or products of manufacturers, whether or not these have been patented, does not imply that these have been endorsed or recommended by FAO in preference to others of a similar nature that are not mentioned.

The views expressed in this information product are those of the author(s) and do not necessarily reflect the views or policies of FAO.

ISSN 2664-1607 (print)

ISSN 2664-1615 (electronic)

ISBN 978-92-5-133570-3

(c) FAO, 2020

\section{(c) $(1)(9)$}

Some rights reserved. This work is made available under the Creative Commons Attribution-NonCommercial-ShareAlike 3.0 IGO licence (CC BY-NC-SA 3.0 IGO; https://creativecommons.org/licenses/by-nc-sa/3.0/igo/legalcode).

Under the terms of this licence, this work may be copied, redistributed and adapted for non-commercial purposes, provided that the work is appropriately cited. In any use of this work, there should be no suggestion that FAO endorses any specific organization, products or services. The use of the FAO logo is not permitted. If the work is adapted, then it must be licensed under the same or equivalent Creative Commons licence. If a translation of this work is created, it must include the following disclaimer along with the required citation: "This translation was not created by the Food and Agriculture Organization of the United Nations (FAO). FAO is not responsible for the content or accuracy of this translation. The original [Language] edition shall be the authoritative edition."

Disputes arising under the licence that cannot be settled amicably will be resolved by mediation and arbitration as described in Article 8 of the licence except as otherwise provided herein. The applicable mediation rules will be the mediation rules of the World Intellectual Property Organization http://www.wipo.int/amc/en/mediation/rules and any arbitration will be conducted in accordance with the Arbitration Rules of the United Nations Commission on International Trade Law (UNCITRAL).

Third-party materials. Users wishing to reuse material from this work that is attributed to a third party, such as tables, figures or images, are responsible for determining whether permission is needed for that reuse and for obtaining permission from the copyright holder. The risk of claims resulting from infringement of any third-party-owned component in the work rests solely with the user.

Sales, rights and licensing. FAO information products are available on the FAO website (www.fao.org/publications) and can be purchased through publications-sales@fao.org. Requests for commercial use should be submitted via: www.fao.org/contact-us/ licence-request. Queries regarding rights and licensing should be submitted to: copyright@fao.org. 


\section{Contents Sourcebook}

Preface

Acknowledgements

Acronyms and abbreviations

Introduction

(i) FAO and CITES

(ii) Implementing CITES through national fisheries legal frameworks: a study and a guide

A study on implementing CITES through national fisheries legal frameworks

1. Structure and relevance

2. Contextualizing CITES and the fisheries sector

3. General implementation of CITES by parties

4. Other CITES implementation activities

Concluding remarks

Annexes

A guide for implementing CITES through national fisheries legal frameworks

1. Scope and structure $\quad 85$

2. Purpose 285

3. The CITES National Legislation Project $\quad 87$

4. Other FAO legal guides and tools for reviewing and strengthening fisheries legal frameworks 90

5. Preliminary considerations 93

6. Legislative options for implementing CITES through national fisheries legal frameworks 103

Summary table of legislative options for implementing CITES through national fisheries legal frameworks 



\section{Preface}

In recent years, an increasing number of commercially exploited and managed aquatic species, including sharks and rays, have been listed in the Appendices to the Convention on International Trade in Endangered Species of Wild Fauna and Flora (CITES). The listing of some species in CITES Appendix II has necessitated attention from the fisheries sector of States on how listing would impact on the management of the relevant fisheries.

CITES is an important instrument for regulating international trade in aquatic species, including those which are, and can be, commercially exploited and which are being managed by the fisheries sector. Many State parties to CITES are also parties to other international fisheries instruments including: the UN Law of the Sea Convention; the UN Fish Stocks Agreement; the Compliance Agreement and the Agreement on Port State Measures to Prevent, Deter and Eliminate IUU fishing. These States are obliged to implement CITES in addition to these international fisheries instruments. Consequently, ignoring the impact of CITES requirements, particularly as regards commercially exploited and managed fisheries resources, is not an option.

Fisheries sector legal frameworks will have to recognize and enable the various requirements provided for in CITES. Examples include the making of non-detriment findings and ensuring that there is a designated management authority and scientific authority to take certain decisions in respect of listed commercially exploited and managed aquatic species. These requirements are normally established and elaborated in fisheries legislation and policy. Consequently, there is a need for States, which manage important fisheries impacting on the wellbeing of CITES-listed aquatic species, to carry out a dedicated legal analysis. This entails examining their national legal frameworks providing for the implementation of CITES in conjunction with an examination of their national fisheries legal frameworks. This will ensure these frameworks are mutually complementary and provide a seamless regulatory environment for all actors falling within the fishing sector. This comprehensive examination should naturally result either in the development of new legislation, or the realignment and strengthening of existing national legal frameworks to address identified regulatory gaps. These legislative outcomes should ensure that trade in listed commercially exploited and managed aquatic species is not unduly hindered and that the goals of ensuring conservation and long-term sustainability of the relevant species are attained.

Although guidance has been provided by the CITES Secretariat on how to review, assess and develop CITES-specific national legislation, there has been minimal guidance for States keen to explore whether their national fisheries legal frameworks can enhance their fisheries management regime while simultaneously contributing to the implementation of CITES. This sourcebook addresses the need to enhance understanding of CITES and its relationship with the fisheries sector, and to assess and enhance national fisheries legal frameworks to optimize the implementation of CITES. It is a two-part sourcebook consisting of a study and a guide. The sourcebook is a product of the collaborative initiative of FAO, in particular, the Development Law Service of FAO's Legal Office and FAO's Fisheries and Aquaculture Department, working together with the CITES Secretariat. The guide, in particular, is designed to help States with their implementation of CITES through enhanced national legal frameworks for fisheries, thereby contributing to the sustainability of species, biodiversity and ecosystems.

This sourcebook and the research process involved in developing it highlighted the opportunity to implement CITES through national fisheries legal frameworks. Indeed, in certain cases, doing 
so can prove to be vital in giving practical effect to CITES on the ground while simultaneously enhancing fisheries management regimes and ensuring that all activities along the fisheries value-chain, especially the international trade in CITES-listed aquatic species, are legal, traceable and sustainable. The study recognizes that communities operating within the CITES regime and in the fisheries sectors have their own particular areas of work. However, they should cooperate and coordinate their work where they share the common high-level objectives of ensuring responsible, legal and sustainable utilization of resources, including species, biodiversity and ecosystems, and implementing the relevant Sustainable Development Goals.

The realization of this sourcebook in 2020, designated as a "super year" for nature and biodiversity, represents a timely and useful contribution to fisheries management as it seeks to provide support in: (i) raising awareness of CITES; (ii) enhancing comprehension of the CITES regime and its relationship with the fisheries sector and (iii) where a deliberate decision is made by a country to implement CITES through its national fisheries legal frameworks, providing guidance on what to do and how to do it. 


\section{Acknowledgements}

The work leading to the production of this sourcebook was supported by the EU-funded project aimed at ensuring the sustainability, legality and traceability of international trade in CITES-listed species (EP/INT/334/UEP). Funding for the development, copy-editing and publication of this sourcebook was provided by two projects. The first concerns supporting the application of the ecosystem approach to fisheries management considering climate change and pollution impacts (GCP/GLO/690/NOR) under the EAF-Nansen Programme. The second concerns delivering sustainable environmental, social and economic benefits in West Africa through good governance, correct incentives and innovation (GCP/RAF/837/GFF) under the Coastal Fisheries Initiative Programme.

The realization of this sourcebook would not have been possible without the collaboration of many professional colleagues, including FAO staff and the participants of the expert workshop (FAO, Rome, 6 to 8 May 2019) and its focused follow-up meeting (FAO, Rome, 17 to 18 February 2020). For their invaluable support in the preparation of this work, the authors are most grateful to colleagues within the Development Law Service of FAO's Legal Office, namely: Pio Manoa who provided counsel and reviewed an earlier version of this sourcebook; Minmin Lei; Elizabeth-Rose Amidjogbe and Buba Bojang. Appreciation is also due to colleagues in FAO's Fisheries and Aquaculture Department, namely: Kim Friedman; Shelley Clarke; YoonJee Kim; and Safa Gritli.

This sourcebook was subjected to a peer-review process coordinated by the GreenLaw Foundation (Kevin Pretorius, Johann Vermeulen and their associates) to whom the authors are grateful. All technical inputs, comments and suggestions provided by reviewers assisted in immensely improving this sourcebook and are very much appreciated. For these, the authors wish to thank Sofie Flensborg and Daniel Kachelriess of the CITES Secretariat; Sylvia Bankobeza of the United Nations Environment Programme (UNEP); Jenna Dawson and Lejda Toci of the United Nations Office on Drugs and Crime (UNODC); Alexa Cole; Erik J. Molenaar; Fábio Hazin; Ganesan Vetiah; Kaluhath Vikum; Priyantha De Abrew; Philippe Cacaud; and Stefán Ásmundsson.

Additional information and comments by Federico Castrogiovanni of the Italian Ministry for Environment, Land and Sea; Giovanni Broussard of UNODC; David Agnew and Bonney Webb of the Commission for the Conservation of Antartic Marine Living Resources (CCAMLR); Nicola Ferri of the General Fisheries Commission for the Mediterranean (GFCM); Jenny Cheatle of the International Commission for Conservation of the Atlantic Tunas (ICCAT); and Paul De Bruyn of Indian Ocean Tuna Commission (IOTC) are also appreciated. Finally, the authors wish to thank Phil Glover for editing the sourcebook, and Jessica Marasovic for her work on graphic design and layout. 


\section{Acronyms and abbreviations}

\begin{tabular}{|c|c|}
\hline ABNJ & Areas beyond national jurisdiction \\
\hline ABT & Aichi Biodiversity Target \\
\hline BLG & Biodiversity Liaison Group \\
\hline BMIS & Bycatch Management Information System \\
\hline CBD & Convention on Biological Diversity \\
\hline CCAMLR & Commission for the Conservation of Antarctic Marine Living Resources \\
\hline CCRF & Code of Conduct for Responsible Fisheries \\
\hline CDS & Catch documentation scheme \\
\hline CECAF & Fishery Committee for the Eastern Central Atlantic \\
\hline CITES & Convention on International Trade in Endangered Species of Wild Fauna and Flora \\
\hline CMS & Convention on the Conservation of Migratory Species of Wild Animals \\
\hline CNM & Cooperating Non-Member \\
\hline CNCP & Cooperating Non-Contracting Party \\
\hline COFI & Committee on Fisheries (FAO) \\
\hline CoP & Conference of the Parties (CITES) \\
\hline CP & Contracting Party \\
\hline EAF & Ecosystem approach to fisheries \\
\hline EEZ & Exclusive economic zone \\
\hline EU & European Union \\
\hline FA & Fisheries Authority \\
\hline FAO & Food and Agriculture Organization of the United Nations \\
\hline FGIS & Fisheries Global Information System \\
\hline $\mathrm{Fl}$ & FAO's Fisheries and Aquaculture Department \\
\hline FMP & Fisheries management plan \\
\hline GFCM & General Fisheries Commission for the Mediterranean \\
\hline IATA & International Air Transport Association \\
\hline IATTC & Inter-American Tropical Tuna Commission \\
\hline ICCAT & International Commission for the Conservation of Atlantic Tunas \\
\hline ICRW & International Convention for the Regulation of Whaling \\
\hline ICCWC & International Consortium on Combating Wildlife Crime \\
\hline IFS & Introduction from the sea \\
\hline INTERPOL & International Criminal Police Organization \\
\hline IOTC & Indian Ocean Tuna Commission \\
\hline IPOA & International Plan of Action \\
\hline IPOA-IUU & $\begin{array}{l}\text { International Plan of Action to Prevent, Deter and Eliminate Illegal, Unreported and } \\
\text { Unregulated Fishing }\end{array}$ \\
\hline IPOA-Sharks & International Plan of Action for the Conservation and Management of Sharks \\
\hline IPOA-Seabirds & International Plan of Action for Reducing Incidental Catch of Seabirds in Longline Fisheries \\
\hline ITLOS & International Tribunal for the Law of the Sea \\
\hline IUU & Illegal, unreported and unregulated (fishing) \\
\hline IUCN & International Union for Conservation of Nature \\
\hline & International Whaling Commission \\
\hline
\end{tabular}


LAF

LEGN

LOSC

MA

MCS

$\mathrm{MoU}$

NAFO

NDF

NEAFC

NGO

NLP

NPFC

PSMA

PT

RECOFI

RFB

RFAB

RFMO/A

SA

SEAFO

SEAFDEC

SPRFMO

SDG

SSF

UN

UNEP

UNFSA

UNODC

WCPFC

WECAFC

WCO

WoRMS
Legal acquisition finding

Development Law Service of FAO's Legal Office

UN Law of the Sea Convention 1982

Management Authority (CITES designated)

Monitoring, control and surveillance

Memorandum of Understanding

Northwest Atlantic Fisheries Organization

Non-detriment finding

North East Atlantic Fisheries Commission

Non-governmental organization

National Legislation Project

North Pacific Fisheries Commission

Agreement on Port State Measures to prevent, deter and eliminate Illegal, Unreported and Unregulated Fishing

Participating Territory

Regional Commission for Fisheries

Regional fishery body

Regional fishery advisory body

Regional fisheries management organization/arrangement

Scientific Authority (CITES designated)

South-East Atlantic Fisheries Organization

South-East Asian Fisheries Development Centre

South Pacific Regional Fisheries Management Organization

Sustainable Development Goal

Small-scale fisheries

United Nations

United Nations Environment Programme

Agreement for the Implementation of the Provisions of the United Nations Convention on the Law of the Sea relating to the Conservation and Management of Straddling Fish Stocks and Highly Migratory Fish Stocks

United Nations Office on Drugs and Crime

Western and Central Pacific Fisheries Commission

Western Central Atlantic Fishery Commission

World Customs Organization

World Register of Marine Species 



\section{Introduction}

The 1970s marked significant progress in the development of international law relating to environmental protection and conservation. Amid a number of concerns, emphasis was placed on the need to safeguard and wisely manage humankind's heritage of wildlife, its habitat, and to ensure the conservation of nature (Stockholm Declaration, 1972, Principle 4). Recognizing that certain species of wild animals and plants required protection from the threat of extinction, particularly from over-exploitation by commercial interests, States adopted, in 1973, the Convention on International Trade in Endangered Species of Wild Fauna and Flora (hereafter CITES) which entered into force two years later (CITES, 1973). CITES is one of the most vibrant multilateral environmental agreements, with near-universal participation 183 parties comprising 182 States and the European Union (EU).

CITES regulates and provides for the monitoring of international trade in species and specimens of certain terrestrial and aquatic animals and plants listed in its three Appendices. Founded on the recognition that "wild fauna and flora in their many beautiful and varied forms [and as] irreplaceable part[s] of the natural systems of the earth" (CITES, 1973, Preamble, Paragraph 1) require protection, CITES aims to protect species listed within its Appendices against overexploitation by international trade and promotes cooperation among the parties seeking to ensure that any such trade is legal, sustainable and traceable. Appendix I includes species threatened with extinction in which trade is strictly restricted and authorized only for noncommercial scientific or educational purposes. Appendix II includes species which, although not necessarily threatened with extinction, may become so unless trade in them is regulated to ensure that it is not detrimental to their survival. Appendix III includes those species and specimens that are protected by legislation enacted and in force within the jurisdiction of a party and for which trade requires control in cooperation with other parties (CITES, 1973, Appendix III, Article II (1)(2)(3)).

Approximately 5800 animal species and 30000 plant species are listed in the CITES Appendices. Just less than 1 percent are listed in Appendix I, with about 97 percent appearing in Appendix II and about 3 percent in Appendix III. Examples of aquatic animals included in the CITES Appendices since its entry into force include certain species of sturgeon, lungfish, otter, whale and dolphin. More recently, an increasing number of commercially exploited and managed marine species, notably certain species of shark and ray, have been listed in Appendix II to the Convention. This means that international trade in them can continue, but that parties need to ensure that such trade is conducted in a legal, sustainable and traceable manner.

CITES regulation of international trade in those species may contribute to improving the management, monitoring, control, surveillance and enforcement of fisheries, as well as in promoting the conservation and sustainable use of fisheries resources. CITES complements the work of specialized fisheries and related entities at global, regional and national level, including various regional fishery bodies (RFBs) and the United Nations Food and Agriculture Organization (FAO) (FAO, 2018a, p. 105). 


\section{(i) FAO and CITES}

Since the 1990s, FAO has been cooperating with CITES in supporting, facilitating and promoting the implementation of CITES in the fisheries domain through diverse range of activities (Franckx, 2011). Their initial work comprised improving the collection of data related to the biology and trade in species of shark and shark-derived products. This was an issue raised in both the CITES 9th Conference of the parties (COP) in 1994 and the 21st session of FAO's Committee on Fisheries (COFI) in 1995 (COFI, 1995; FAO, 1995; CITES, 1994b). By the commencement of the 21st century, additional matters came to the fore, and these discussions increased, especially under the auspices of FAO's Sub-Committee on Fish Trade (Franckx, 2011, p. 10; CITES, 2002c). One issue discussed was the application of CITES listing criteria to commercially exploited and managed aquatic species, initially with a view to improving the scientific evaluation of the respective listing proposals. Several technical consultations were undertaken, leading to three main streams of activities and related recommendations:

(1) improvements that could be made to the CITES criteria for listing;

(2) adoption of further guidance in the form of Technical Guidelines on Responsible Fish Trade under the framework of the Code of Conduct for Responsible Fisheries (CCRF) (CCRF, 1995);

(3) application of the CITES provisions on "introduction from the sea" (Franckx, 2011).

In 2006, a Memorandum of Understanding (MoU) between FAO and the CITES Secretariat (hereafter "the Secretariat") was signed, thus formalizing cooperation between them (CITES, 2006). Within the scope of this MoU, a number of activities were carried out, including participation in two consecutive EU-funded projects (2013-2017 and 2017-2020). The first of these, in place since 2013, was entitled CITES-FAO Collaboration to Strengthen the Capacity of Developing Countries to Ensure the Sustainability, Legality and Traceability of International Trade in CITES-listed Species, with a Focus on Commercially-exploited Aquatic Species (hereafter referred to as "the Project"). One of the aims of the Project is to strengthen the capacity in developing countries to ensure the effective implementation of CITES with a focus on commercially exploited and managed aquatic species (UN, 2017). The Project provides a framework for the Secretariat to work in partnership with FAO, RFBs and other stakeholders from the fisheries sector and at the time of publication is in its second phase (2017-2020) of implementation.

The overall objective of the Project is to contribute to the UN's Sustainable Development Goal (SDG) 14, in particular its targets 14.4 and 14.A (UNGA, 2015). This entails: promoting the development and enhancement of scientific knowledge technology and research capacity to assist in the making of non-detriment findings; ensuring lawful harvesting; lawful transport as well as the control and monitoring of trade in order to avoid over-exploitation of species and ensuring the sustainability of fisheries. As part of the Project, FAO's Fisheries and Aquaculture Department (FI), the Development Law Service of FAO's Legal Office (LEGN) and the CITES Secretariat have been exploring and developing ideas and considerations to implement CITES through national fisheries legal frameworks. The specific objective of this cooperation was to develop a guidance document for the implementation of CITES through enhanced national legal frameworks in the fisheries sector. 


\section{(ii) Implementing CITES through national fisheries legal frameworks: a study and a guide}

In this context, a study was undertaken by LEGN from which a background paper was produced and used to inform experts at a "Implementing CITES through Fisheries Legal Frameworks" workshop hosted at FAO's headquarters in Rome between 6 and 8 May 2019 (hereafter "the CITES Expert Workshop") (FAO, 2019a). Following this workshop, the LEGN background paper was converted into what is now the sourcebook (hereafter "the sourcebook"). ${ }^{1}$ This is a single document comprising two distinct parts. One part is an awareness-raising and knowledgesharing material (hereafter "the study"), which aims to provide an overview of the main issues concerning CITES implementation in national fisheries sectors. The other part is a guidance tool (hereafter "the guide"), which seeks to support legal practitioners and decision-makers working in CITES and national fisheries sectors in reviewing relevant legislation and ensuring that key elements of CITES are taken into account or incorporated in legal provisions when a decision has been taken to implement CITES through the relevant legal framework regulating national fisheries.

The sourcebook is intended for use by relevant public and private stakeholders involved throughout the complete supply-chain and value-chain in international trade of CITES-listed commercially exploited and managed aquatic species. This includes fishers, fisheries managers, low- and high-level authorities dealing with the harvesting of CITES-listed aquatic species, through to maritime, customs, CITES-specific and other relevant authorities working in the areas of transport, control and international trade in such species. The sourcebook goes beyond the implementation of CITES by also covering related, but non-legally-binding instruments, principles and approaches, which are nevertheless key to ensuring the effective implementation of CITES implementation through national fisheries legal frameworks. Its overall objective is to bridge the apparent gap existing between, on the one hand, the communities involved with implementing CITES and on the other, fisheries management entities, with a view to promoting their interaction. It does not intend to impose ideas on each other or replace one with the other.

The study and the guide are tools ready for use separately as stand-alone documents, but are presented here in a single sourcebook. If the reader's intention is to gain an understanding of the actual CITES regime and how it links to the fisheries sector and related issues, then the study is more useful. The study, as a knowledge product, discusses the complexities underpinning the relationship between CITES and national fisheries management and regulatory regimes with a view to developing an appreciation of the potential role that CITES regulatory approaches and tools can play in the fisheries sector and vice versa. If these matters are already well understood and the objective is to move towards implementing CITES in the fisheries sector and to that end, enhance national fisheries legal frameworks, then the guide is more appropriate.

\footnotetext{
The sourcebook was subject to a peer-review process coordinated by the Green Law Foundation, involving about ten high-level experts in the international fisheries law field as well as experts on CITES and related issues. After this peer-review process was finalised, the consolidated revised version was also discussed in an informal meeting held at FAO's headquarters in Rome between 17 and 18 February 2020. Some of the experts who participated in the CITES Expert Workshop also participated in this meeting as well as other experts, including one representative of the Indian Ocean Tuna Commission and the International Commission on the Conservation of the Atlantic Tunas.
} 



\section{STUDY}

A study on implementing CITES through national fisheries legal frameworks 



\section{Contents Study}

A study on implementing CITES through national fisheries legal frameworks

1. Structure and relevance

2. Contextualizing CITES and the fisheries sector 9

$\begin{array}{ll}2.1 \text { A brief overview of CITES } & 9\end{array}$

$\begin{array}{ll}2.2 & \text { Amendments to CITES and follow-up procedures } \\ \end{array}$

2.2.1 Inclusion of aquatic species in the CITES Appendices 10

2.2.2 Interaction between the CITES regime and the fisheries sector 12

2.2.3 Opportunities for cooperation, coordination and mutual complementarity 14

3. General implementation of CITES by parties 15

3.1 Operationalizing "introduction from the sea" 15

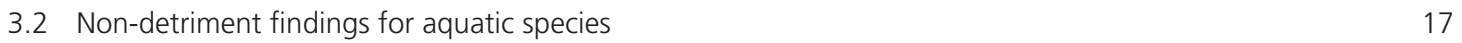

$\begin{array}{ll}3.3 \text { Legal acquisition findings } & 18\end{array}$

\begin{tabular}{ll}
3.4 & Voluntary export quotas \\
\hline
\end{tabular}

3.5 Requirements for the transport of live specimens 21

3.6 Options for the disposal of illegally traded and confiscated fish specimens 22

4. Other CITES implementation activities 23

4.1 CITES partnerships on biodiversity conservation and wildlife crime 23

4.2 FAO's technical assistance, tools, guidelines and plans of action 24

4.3 Potential contributions of Regional Fishery Bodies to CITES implementation 26

$\begin{array}{lll}\text { 4.4 Fisheries measures in the CITES regime and vice versa } & 28\end{array}$

$\begin{array}{lr}\text { Concluding remarks } & 29\end{array}$

$\begin{array}{ll}\text { References } & 31\end{array}$

Annexes

$\begin{array}{lll}\text { Annex A } & \text { Overview of trade activities and related CITES requirements } & 42\end{array}$

Annex B.1 CITES-listed fish species primarily harvested by the fisheries sector (as at February 2020). 43

Annex B.2 CITES-listed aquatic species which are generally considered as not primarily harvested and traded by the fisheries sector, but may be considered as such if accidentally caught as bycatch, or become the subject of other fishing activities or fishing related activities (as at February 2020).

Annex C.1 List of Regional Fisheries Management Organizations/Arrangements' selected measures relevant for CITES implementation (as at February 2020)

Annex C.2 List of Regional Fishery Advisory Bodies' selected measures relevant for CITES (as at February 2020) 66

Annex D CITES implementing legislation placed in Category 1 under the National Legislation Project 67

Annex E Selected fisheries legislation identified as relevant for the purpose of implementing CITES $\quad 79$ 
Figures

Figure Where the fisheries sector and CITES interact

Table 1 Scenarios ("S." ) of species being harvested in Areas Beyond National Jurisdiction and landed in a given State, according to interpretation by CITES Parties in Resolution Conf. 14.6 (Rev. CoP16)

Table 2 Examples of CITES Appendix II-listed fish species subject to voluntary national export quotas

Table 3 Select FAO's instruments and guiding documents relevant to CITES implementation

Table 4 Correlations between outputs of the CITES regime and fisheries management 


\section{A study on implementing CITES through national fisheries legal frameworks}

\section{Structure and relevance}

This study, structured in four parts, represents the more analytically-focused component of the sourcebook. It is designed to help the user to better understand the issues arising from the inclusion of commercially exploited and managed aquatic species in CITES Appendix II.

Part 1 contextualizes the relationship between the CITES regime and the fisheries sector. It provides an overview of how CITES works, a comparison of the objectives and practices of CITES and fisheries management, as well as areas of convergence and common concerns shared by CITES and the fisheries sector.

Part 2 describes how parties have gone about implementing CITES at the national level. There is a particular focus on legislative procedures, non-detriment findings, voluntary export quotas, operationalizing introduction from the sea, transport of live specimens and disposal of illegally traded and confiscated specimens.

Part 3 provides an overview of specific cooperative actions undertaken by States either directly or through membership of international organizations, including actions on matters potentially extending beyond the CITES regime. There is a particular focus on cooperative activities within the fisheries sector undertaken by FAO and RFBs.

Part 4, the conclusion, highlights the importance of fostering cooperation and coordination between the CITES regime and the fisheries sector so that each can strengthen and effectively complement the other's activities. Where appropriate, this includes creating opportunities to achieve more sustainable and responsible international fisheries trade.

\section{Contextualizing CITES and the fisheries sector}

\subsection{A brief overview of CITES}

International trade in species as regulated by CITES is defined as export, import or re-export and introduction from the sea (CITES, 1973, Article I). Regulation differs according to the type of trade activity and by reference to the relevant CITES Appendix in which the particular species is listed. Export and import permits, as well as certificates authorizing re-export and introduction from the sea, are granted by the respective party's designated Management Authority (hereafter "MA"). These are issued when certain requirements are met, comprising the advice of the competent MA and the party's designated Scientific Authority (hereafter "SA") (CITES, 1973, Articles III, IV, V and IX (1)(a)). All parties are required to regulate trade in Appendiceslisted species in violation of CITES and to take appropriate enforcement measures. These include penalizing trade in, and/or possession of, specimens of such species, and providing for the confiscation or return to the State of export of such specimens. A simplified visualization of the trade activities covered by CITES and its respective requirements is provided in Annex A. 
CITES permits and certificates are not required if the relevant trade is conducted between States that are not parties to the Convention. ${ }^{1}$ However, where export, re-export or import occurs between a party and a non-party, the party may facilitate the trade by accepting comparable documentation to be issued by the respective competent authority of the non-party (CITES, 1973, Article X). Each party is required to designate one or more MAs as well as one or more SAs (CITES, 1973, Articles IX (1)(a)(b) and VIII (1)(a)(b)). Each party may accept what is purported to be comparable documentation from a non-party, provided that such documentation includes the name, stamp and signature of the competent authority, certifying that such MA's and/ or SA's details are included in the online CITES Directory (CITES, 1994a). All 183 parties are bound by all CITES provisions and must accordingly implement them through their legal, policy and institutional frameworks. Some non-parties, including Andorra, Anguilla, Cook Islands, Kiribati, the Federated States of Micronesia and the Marshall Islands, have provided relevant information regarding their competent authorities for the purposes of implementing CITES, but other non-parties, such as Tuvalu, have not yet done so. ${ }^{2}$

\subsection{Amendments to CITES and follow-up procedures}

Following its adoption in 1973, the text of CITES has been amended twice, with (as at October 2020) 149 parties having accepted to be bound by the 1979 Bonn Amendment (CITES, 1979), and 102 parties by the 1983 Gaborone Amendment (CITES, 1983). The Bonn Amendment permits the CoP to adopt financial provisions (CITES, 1979, Article XI (3)(a)), while the Gaborone Amendment permits regional economic integration organizations composed of States (e.g. the EU) to accede to CITES. The primary provisions of CITES, those covering the requirements for trade, have not been amended since its initial adoption. The Conference of the Parties (CoP) reviews the implementation of CITES every three years. As at October 2020, the most recent CoP (the 18th) was held in Geneva, Switzerland, between 17 and 28 August 2019. ${ }^{3}$ There were a number of significant outcomes to this CoP, which are described in greater detail later herein.

Any party is entitled to propose amendments to CITES Appendix I or II for potential adoption by the CoP. Additionally, any party can, at any time, submit a list of species to the Secretariat for inclusion in Appendix III as well as proposed amendments (CITES, 1973, Articles XV and XVI). These proposals may consist of a request to include species in one of the Appendices, to delist species from them or to transfer species from Appendix I to II, or vice versa. Amendments to the Appendices, once accepted, bind parties automatically unless any party enters a reservation (which may be withdrawn) (CITES, 1973, Articles XV (3), XVI (2) and XXIII (3)). The proposals for amendment of Appendix I or II should be based on the best information available and are considered in accordance with a precautionary approach as well as biological, trade and lookalike criteria, as agreed by the parties (CITES, 1994d).

\subsubsection{Inclusion of aquatic species in the CITES Appendices}

A number of aquatic species subject to commercial exploitation, including fish such as cui-ui (Catostomidae), carps (Cyprinidae), arapaima (Arapaimidae), as well as certain species of otters (Lutrinae), seals (Phocidae), whales (Cetacea) and turtles (Testudines), have been listed in the

\footnotetext{
CITES parties can, within 90 days of a new species listing being decided, enter a reservation in respect of the listing of a species (CITES, 1973, Articles XV and $\mathrm{XVI}$ ). For international trade in specimens of listed species for which a CITIES party has made a reservation, it is treated as a non-party in respect of the species specified in the reservation (CITES, 1973, Article XXIII).

See CITES online Registry of national competent authorities (CITES, n.d-h)

See CITES, n.d-d.
} 
Appendices to CITES since its entry into force over forty years ago. Additional aquatic species have been listed since then. Such species are managed, exploited and internationally traded to varying degrees. All species of sturgeon (Acipenseriformes), for example, the source of globally traded caviar (CITES, 2002c), were listed between 1975 and 1998, with most species listed on Appendix II, except two species listed in Appendix I. Certain species of hard coral kept in public aquariums (Antipatharia, Helioporidae, Scleractinia), and constituting a small portion of the trade in corals by the ornamental industry (UNEP-WCMC, 2008), were included in Appendix II between 1981 and 1990.

In 2003, the basking shark (Cetorhinus maximus), from which meat, skin and fins are widely commercially traded (Maguire et al., 2006) and the great whale shark (Rhincodon typus), which is important for ecotourism and whale shark watching (Young, 2011), were included in Appendix II. In 2004, all species of seahorses (Hippocampus), another commercially valuable marine species used in traditional medicine and kept in aquariums (Young, 2011), were listed on Appendix II. In 2005, the Humphead wrasse (Cheilinus undulatus), an important live reef food fish and one of the highest species in unit value (Gillet, 2010), and the great white shark (Carcharodon carcharias) were also listed on Appendix II. The European eel (Anguilla anguilla), a species of commercial interest in the fisheries and aquaculture markets of European countries, including Italy and Spain (Monticini, 2014), was included in Appendix II in 2009.

At CoP16 and CoP17, held in 2013 and 2016 respectively, about 20 commercially exploited and managed fish species were added to CITES Appendices (FAO, 2018, p. 78). These included the oceanic whitetip shark (Carcharhinus longimanus); thresher shark (Alopias); porbeagle shark (Lamna nasus); scalloped hammerhead shark (Sphyrna lewini); great hammerhead shark (Sphyrna mokorran) and the smooth hammerhead shark (Sphyrna zygaena). All devil ray (Mobula) and manta ray (Manta) species were also included in Appendix II (CITES, 2013c; CITES, 2019d).

At the 2019 CoP18, parties decided to list 18 shark species in Appendix II. These included: blackchin and sharpnose guitarfishes (Glaucostegus); shortfin mako shark (Isurus oxyrinchus); longfin mako shark (Isurus paucus); white-spotted and other species of wedgefishes (Rhinidae) (CITES, 2019e). Three species of sea cucumber (Stichopodidae), which are harvested and traded in large volumes worldwide (Purcell, Samyn and Connad), were also included in Appendix II. These recent additions to CITES-listed aquatic species are either targeted by fishing or caught as bycatch, and their high commercial value makes them attractive for the purposes of international trade. Although trade data reported by countries with respect to the aforementioned shark species is limited, trade comprises a significant number of shark commodities, including fins and meat, which are exported and imported by many countries (Mundy-Taylor and Crook, 2013).

The relevant aquatic species included in CITES Appendices and any related reservations to them by parties are provided in two separate tables in Annex B. This Annex contains information on which particular Appendix the species is listed in, the date when such listing became effective, any reservations made by certain parties and other relevant data. ${ }^{4}$ One table (Annex B.1) contains fish species generally considered as being primarily harvested and traded by

\footnotetext{
4 Species listed in CITES were identified as "marine species" relevant for the present discussion by verification in the World Register of Marine Species (WoRMs) database. See WoRMs, 2020, "an authoritative classification and catalogue of marine species". With respect to seabirds, BirdLife International provide a research engine enabling users to identify bird species that are threatened by fishing and harvesting of aquatic resources and only those species were considered in this analysis. See BirdLife International, 2020. With regard to the dates on which listings enter into effect, see UNEP-WCMC (Comps.), n.d., Checklist of CITES Species.
} 
the fisheries sector in marine and inland waters such as: sharks; rays; fishes; seahorses; sea cucumbers; mussels; clams; conches and corals. The other table (Annex B.2) includes aquatic species generally considered as not being primarily harvested and traded by the fisheries sector but which may become so if accidentally caught as bycatch or which may become the subject of other fishing activities or fishing related activities. These species include: otters; seals; whales; dolphins; seabirds; crocodiles and sea turtles.

\subsubsection{Interaction between the CITES regime and the fisheries sector}

International trade is vital to the fisheries sector. Fish and fishery products are among the most traded food commodities in the world, with 38 percent of global fish production (or 67 million tonnes) traded internationally in 2018 (FAO, 2020a). Increase in the international trade of fish and fish products raises concerns surrounding the degree to which it complies with international standards, including the requirements set out in CITES. It is acknowledged that there may be difficulties in accurately assessing the state of all species and that there are data deficiencies. Nevertheless, the 2019 assessment provided by the International Union for Conservation of Nature (IUCN) Red List ${ }^{5}$ identified 2341 species of fish among its list of threatened species. ${ }^{6}$ Of these, 489 were categorized as "critically endangered", 678 as "endangered " and 1174 as "vulnerable".?

Though the majority of internationally traded fish species and specimens, as well as their respective derivative products, are not included in the CITES Appendices, the listing of certain fish species demonstrates a clear linkage between CITES requirements for internationally trading in those species and as regards their management (Dent and Clarke, 2015). Indeed, the listing of certain aquatic species in CITES Appendix II made it necessary that the CITES regime and fisheries sectors work closely together. It has also, however, created tensions between them. Delegates from the same country present at CITES and RFB meetings often adopt different positions with respect to the listing of aquatic species in the CITES Appendices, thus creating some confusion and incoherence in the ongoing dialogue.

It is important that the two communities appropriately communicate and work towards understanding each other so that both can co-exist, coordinate and complement each other's efforts where appropriate. On one hand, it is important for the CITES community to recognize the effects that the listing of commercially exploited and managed aquatic species has on fishing activities. There are challenges faced by developing countries who desire to achieve national development aspirations but have limited capacity and financial resources to implement the relevant provisions of CITES. Moreover, the potential negative effects on livelihoods cannot be taken into account in the listing criteria but become apparent and are recognized or acknowledged only after the listing occurs. On the other hand, it is also important for the fisheries sector to recognize the potential role that effective implementation of CITES may play in complementing existing fisheries management, to improving sustainability in fisheries and to contributing to the battle against illegal, unreported and unregulated (IUU) fishing. For example, CITES only allows international trade in CITES-listed species if such trade is viewed as not being detrimental to the species concerned. Parties must also make a "legal acquisition

\footnotetext{
5 The IUCN Red List was established in 1964 and provides information on the conservation status of the world's animal, fungi and plant species. It has so far assessed more than 96500 species, of which 26500 were identified as threatened with extinction, including $40 \%$ of amphibians, 34\% of conifers, $33 \%$ of reef building corals, $25 \%$ of mammals and $14 \%$ of birds. See IUCN, n.d-a.

See IUCN, n.d-b.

See IUCN, n.d-c
} 
finding", that is, be satisfied that the specimens being traded have been legally acquired (see Subsection 3.3).

Consequently, it will be helpful, as a start, to clarify where the CITES regime and the fisheries sector interact, namely, where a fishery engages in an international trade transaction (i.e. import, export, re-export, or introduction from the sea - see Figure), involving a CITESlisted aquatic species.

\section{Figure}

Where the fisheries sector and CITES interact

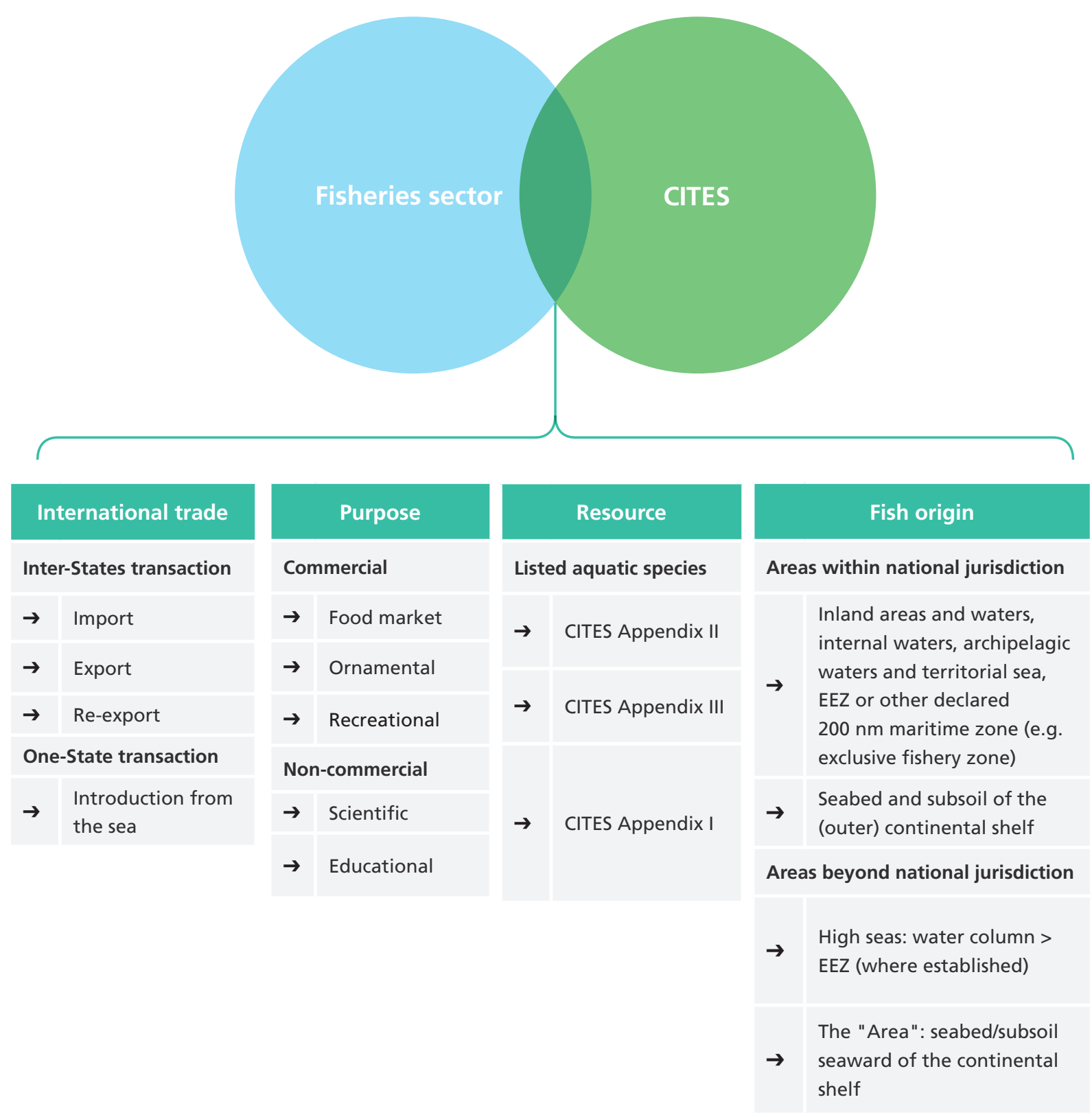


Notwithstanding the fact that the fisheries sector and the CITES regime do not interact, at least not directly in many cases, it is important to analyse and thus precisely clarify where common concerns and convergence occur so that both have the opportunity to collaborate on an improved basis. This elucidation can help to address sensitive questions, such as whether the CITES regime provides an appropriate forum to discuss fisheries conservation and management measures (Guggisberg, 2016; Young, 2011). It can also identify opportunities that already exist or that may be further developed and improved to enable appropriate interaction between the CITES regime and the fisheries sector. Improving general knowledge on the relationships between these two areas may also serve to better facilitate the balance of parties' interests in the functioning of CITES, ensuring that they fully understand what is the underlying common concern of the two communities; namely the need for the sustainable use of aquatic resources (species, biodiversity and ecosystems) (CITES, 2019b).

\subsubsection{Opportunities for cooperation, coordination and mutual complementarity}

An emerging practice of States in their implementation of CITES has been the designation of their national Fisheries Authorities (hereafter referred to as "FA") as CITES Management Authorities (MA) or Scientific Authorities (SA) for marine species. ${ }^{8}$ This has brought about an opportunity for strengthened cooperation and coordination. In Sri Lanka, for example, the FA (Department of Fisheries and Aquatic Resources) is designated as one of the six SAs. ${ }^{9}$ Malaysia's two FAs (the Department of Fisheries and the Fisheries Research Institute) are included in the total of seven designated SAs. ${ }^{10}$ In countries where the FA is not among the designated CITES authorities (e.g. Brazil ${ }^{11}$ and South Africa) the relevant government needs to ensure that there is strong inter-agency coordination and cooperation. This will involve other relevant authorities including maritime, port, customs and defence authorities. The CITES community is aware of this need, with the recently revised Resolution Conf. 12.6 (Rev. CoP18) on "Conservation and Management of Sharks" (hereafter referred to as the "Sharks Resolution") (CITES, 2002c), encouraging parties to improve coordination between relevant national focal points. This cooperation and coordination can best be ensured by establishing clear, delineated, compatible and harmonious mandates for each of those authorities in relation to legislation and policy, as well as through mechanisms which enable and promote cooperation and coordination between them with respect to the international trade of commercially exploited and managed CITES-listed aquatic species. ${ }^{12}$

The following section examines how the parties have generally implemented CITES in respect of aquatic species. It will be demonstrated that some relevant issues arising as a consequence of implementation help to identify other potential areas where the CITES regime and the fisheries sector can cooperate and coordinate, thus complementing their respective pursuit of their common high-level objectives. It highlights, where appropriate, the relationships between these CITES-specific activities with the fisheries sector and any related implications.

\footnotetext{
8 All parties to CITES are required to designate at least one MA and SA, but they can also designate multiple SAs and Mas. See (CITES, 1973, Article IX). The SA should be independent of the MA.

9 In Sri Lanka, the MA is the Department of Wildlife Conservation, and there are six designated SAs, including that Department and the Departments responsible for National Botanic Gardens; National Zoological Gardens; National Museums; Fisheries and Aquatic Resources and Forests. See CITES, n.d-k.

${ }^{10}$ In Malaysia, there are designated SAs specifically for marine mammals, freshwater fish and for turtles (Department of Fisheries) The Department of Fisheries is also the designated MA for fish, marine mammals and marine plants (First Schedule of International Trade in Endangered Species Act 2008), and for corals, seahorse and sea anemones (Fisheries Research Institute). See CITES, n.d-f.

11 In Brazil, the MA is the Brazilian Institute of Environment and Renewable Natural Resources (IBAMA) and the SAs include the IBAMA as well as the Forest Products Laboratory, the Rio de Janeiro Botanical Garden and the Chico Mendes Institute for Biodiversity Conservation (ICMBio). See CITES, n.d-C.

${ }_{12}$ An example of effective collaboration between the CITES authorities and the FA seems to occur in the United States of America, where the CITES designated SA, the US Fish and Wildlife Service, has coordinated usefully with the FA, the National Oceanic and Atmospheric Administration (NOAA Fisheries). This information was shared during the CITES Expert Workshop (FAO, 2019a). For information on US designated CITES authorities, see CITES, n.d-m.
} 


\section{General implementation of CITES by parties}

\subsection{Operationalizing "introduction from the sea"}

In the text of CITES, introduction from the sea (IFS) is defined as "transportation into a State of specimens of any [CITES listed] species which were taken in the marine environment, not under the jurisdiction of any State" (CITES, 1973, Article I (e)). ${ }^{13}$ This definition is broad and could be applied to different situations which correspond with import, export or re-export. The legal interpretation of the IFS provision was subject to several discussions by parties - led by the CITES Secretariat and FAO - which finally resulted in the guidance agreed by the parties in Resolution Conf. 14.6 (Rev. CoP16) on Introduction from the Sea (hereafter referred to as "IFS Resolution"). Recognizing that further guidance was needed to facilitate the standard implementation of trade controls for "introduction from the sea", the IFS Resolution clarified the practical implementation of these provisions, highlighting which specific situation would be labelled as IFS and would trigger the application of specific requirements under CITES Articles III(5) and IV(6)(7) and what situations will be considered and treated as "imports" and "exports" (see Table 1).

Among other issues, the parties agreed that the definition of "marine environment not under the jurisdiction of any State" is the

marine areas beyond the areas subject to the sovereignty or sovereign rights of a State consistent with international law, as reflected in the United Nations Convention on the Law of the Sea [LOSC].

This clarification was essential in order to understand which of the CITES requirements apply in the many scenarios involving fishing for a CITES-listed species in areas beyond national jurisdiction (ABNJ) and landing it in port. Only situations where species are harvested in ABNJ by a vessel and landed in that vessel's own flag State are treated as IFS (CITES, 2007a). In this case, the MA of the vessel's flag State needs to issue an IFS certificate, based on confirmation that the introduction will not be detrimental to the survival of the species. This confirmation is subject to assessment conducted by the SA (CITES, 1973, Articles III (5)(a) and IV (6)(a)).

An IFS certificate is thus only required in a one-State transaction involving species listed in Appendices I and II and taken from the high seas, but not those listed in Appendix III. Other instances of transportation into a State of species taken from ABNJ will be treated differently; as an import, export or a re-export. The IFS Resolution recommends that, prior to issuing an import permit, export permit or an IFS certificate for specimens harvested in ABNJ, parties (i.e. their competent MA) take into account whether or not the specimen was or will be acquired and landed in a manner consistent with applicable measures under international law and not as a consequence of any IUU fishing activity. The CoP in Resolution 12.3 (Rev. Cop18) on permits and certificates further recommends that parties use source " $X$ " for specimens taken in "the marine environment, not under the jurisdiction of any State" (CITES, 2002a, Paragraph 3(j)).

\footnotetext{
${ }^{13}$ The marine environment not under the jurisdiction of any State or areas beyond national jurisdiction consists of the high seas (water column) beyond exclusive economic zones (EEZ) or other 200 nautical miles zones (where established) as well as the seabed and subsoil beyond the (outer) continental shelves of coastal States, also known as the "Area".
} 


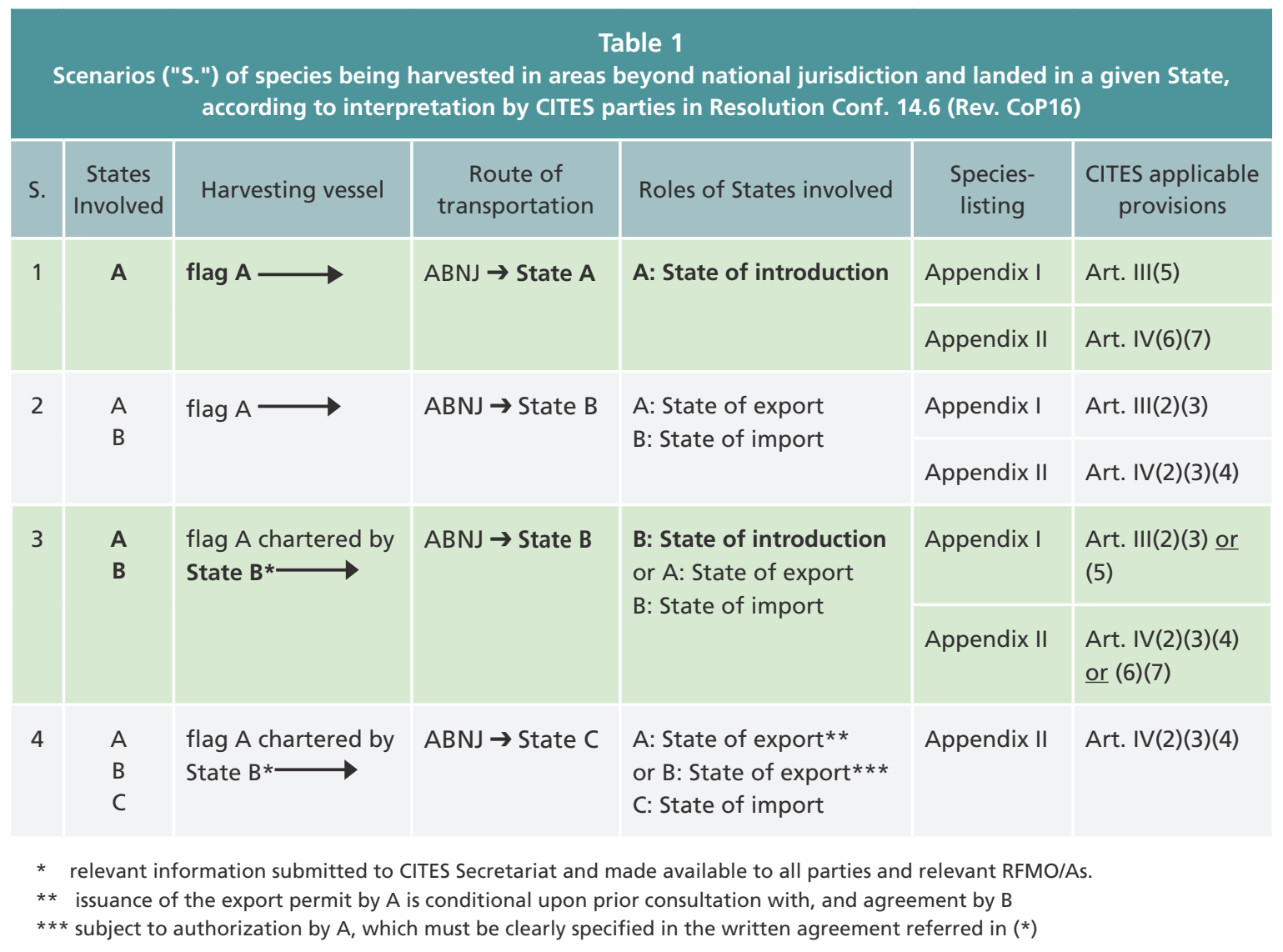

Explanatory notes relating to the implementation issues raised in such situations were also provided in the IFS Resolution (CITES, 2007a, Annex). These different situations and applicable CITES provisions are illustrated in Table 1. The IFS Resolution also clarified that transshipment would only serve as a "means of transportation and the same considerations for IFS should apply" (CITES, 2007a). ${ }^{14}$ This means that, depending on the flag State of the fishing and transshipment vessel, an export permit might have to be issued prior to transshipment or an IFS certificate has to be issued upon landing. With respect to the agreed provisions related to chartering arrangements within the IFS context, the CoP16 and CoP17 have resulted in important decisions aimed at promoting the collection of information on the experiences of the parties. ${ }^{15}$

Pursuant to instructions by the 69th Standing Committee ${ }^{16}$ the CITES Secretariat had issued an official Notification to the parties to submit information as to the challenges they face in implementing the IFS Resolution. From the responses received, the Secretariat found that only a low number of parties had national legislation or regulation in place to implement IFS and, more specifically, the guidance contained in the IFS Resolution (CITES, 2018b). Only 11 parties (Australia, Canada, China, Côte d'Ivoire, Guatemala, Indonesia, Japan, Norway, New

\footnotetext{
14 See also Clarke, Manarangi-Trott and Brouwer, 2014, at 3-6.

${ }^{15}$ CITES, Decisions 16.48, 16.49, 16.50 and 16.51(Rev. CoP17) and 17.181

${ }^{16}$ As outlined in CITES website, "the CITES Standing Committee provides policy guidance to the Secretariat concerning the implementation of the Convention and oversees the management of the Secretariat's budget. Beyond these key roles, it coordinates and oversees, where required, the work of other committees and working groups; carries out tasks given to it by the Conference of the Parties; and drafts resolutions for consideration by the Conference of the Parties" See CITES, n.d-I.
} 
Zealand, Uruguay, and the United States of America) submitted their relevant information to the Secretariat, ${ }^{17}$ and only Japan reported having applied these chartering provisions (CITES, 2018b; CITES, 2017). ${ }^{18}$

Poland has been the only party to have consulted the Secretariat on the use of chartering provisions in an operation involving the transport of an Appendix II species coming from Antarctica onboard a vessel under the flag of the Russian Federation and chartered by Poland. At the time of publication (July 2020), resolution of the case appears to be pending (CITES, 2018b; CITES, 2017).

\subsection{Non-detriment findings for aquatic species}

Before an export permit can be issued by the competent MA, CITES requires that the SA of the exporting State must have "advised that such export will not be detrimental to the survival of that species" (CITES, 1973, Articles III and IV). These findings are commonly referred to as Non-detriment findings (NDFs). The process for making a NDF is a core element of the international trade requirements of CITES as regards species listed within Appendices I and II. A NDF is not a prerequisite for international trade in species listed in Appendix III. CITES does not define "NDF", but the CoP has adopted non-binding guidance through Resolution Conf. 16.7 (Rev. CoP17) on "Non-detriment findings" (hereafter "the NDF Resolution") (CITES, 2013a). It should be noted that NDFs can take many forms, ranging from oral advice provided by the SA to lengthy written reports.

The CITES Draft Model Law on International Trade in Wild Fauna and Flora (hereafter "the Model Law") recommends that a NDF be defined as a

finding by the Scientific Authority advising that a proposed export or introduction from the sea of Appendix I or II specimens will not be detrimental to the survival of the species and that a proposed import of an Appendix I specimen is not for purposes that would be detrimental to the survival of the species (CITES, n.d-g).

The NDF Resolution recommends that the SA takes into account that a NDF "is the result of a science-based assessment" (CITES, 2013).

The national SA designated by each party is responsible for, among other matters, carrying out this science-based assessment, wherein it verifies that the export, import, re-export or IFS of a species listed in the CITES Appendices I or II, would not be detrimental to the survival of the species the subject of proposed trade. Such findings are usually made on a case-by-case basis, but for many frequently traded species, NDFs are in place for a specific time frame (e.g. two years). If the relevant SA makes a NDF, then that export, import re-export or IFS can proceed, provided that all other requirements for the issue of the respective permits and certificates are met (CITES, 1973, Articles III (2)(a)(3)(a)(5)(a) and IV (2)(a)(3)(6)(a)).

The CoP has in many instances encouraged parties to share experiences and examples of NDFs with the CITES Secretariat, which maintains a webpage to ensure that such information is available to all wishing to avail of it (CITES, n.d-i). These efforts depend on the work undertaken

\footnotetext{
17 Given that only 11 of 173 parties responded, this may not be fully representative of the overall situation. The Secretariat further reported that, based on CITES trade data, few overall transactions, and in particular even fewer commercial transactions, were reported under IFS. The Annex to the Secretariat's report contains some examples of how the parties are currently implementing IFS.

${ }_{18}$ In the case of Japan, two chartering agreements between Japan and other countries operating on the high seas were advised to release live CITES-listed shark species and not to allow their retention on board.
} 
by the parties' SAs to facilitate the exchange of scientific data. Although NDFs are based on considerations established by the designated SAs of the parties, the SAs are encouraged to take into consideration the concepts and principles agreed by the parties for those purposes. These include ensuring that NDFs are based on the best available scientific information (CITES, 2019b), consider the volume of legal and illegal international trade as well as data requirements relative to vulnerable species and accurate identification of species and specimen being traded (CITES, 2013).

Parties have also been called upon to make use of the Principles and Guidelines for the Sustainable Use of Biodiversity (CITES, 2004a). Although not directly applicable to the making of NDFs, these are useful guiding instruments which call on parties to take into account the recommendations of the CITES Animal and Plants Committees (CITES, 2012). With respect to marine species, the CoP has encouraged parties to strengthen the efforts of exporting parties in developing NDFs for sharks and rays through an exchange of knowledge and experiences (CITES, 2002c). Some parties have made their NDFs and the NDF associated guidance available on the CITES website (CITES, n.d-e).

Notably, Germany's NDF guidelines, which were developed with regard to making of NDFs for shark species listed in CITES Appendix II (Mundy-Taylor et al., 2014) and which many of the other NDF examples on the CITES website are based, have addressed the preparation of NDFs for transboundary fish stocks occurring in maritime zones of coastal States and/or on the high seas (Mundy-Taylor et al., 2014, p. 108). ${ }^{19}$ These NDFs can be developed and issued in consultation with RFBs acting as the "international scientific authority" for those shared stocks taken on the high seas in accordance with CITES, Article IV $(7)^{20}$ but do not represent a substitute for a national SA (Mundy-Taylor et al., 2014). The Sharks Resolution invites parties to collect and share data through RFBs in respect of fishing effort, catches, live releases, discards, landings and trade in shark species and to make this data available to assist SAs in the making of NDFs for such species.

A guide to making NDFs for tortoises (Testudinidae) and freshwater turtles (Testudines) was recently prepared by the CITES Secretariat (CITES, 2015). At national level, Japan's NDF guidelines for aquatic species were prepared by the Fisheries Agency of Japan, their designated SA. Some parties have also prepared their NDFs for aquatic species and shared them on the CITES website. NDFs with recommendations were made by Sri Lanka for Silky sharks (Carcharhinus falciformis) and Hammerhead sharks (Sphyrna lewini, Sphyrna mokorran and Sphyrna zygaena). India prepared NDFs for Hammerhead sharks (Sphyrna lewini, Sphyrna mokorran and Sphyrna zygaena), Oceanic whitetip sharks (Carcharhinus longimanus) and Giant manta ray (Manta birostris). Another example is the conclusion by New Zealand that the issuance of a NDF for any Spinetail devil ray products would not be possible given that the Spinetail devil ray (Mobula japonica) itself is fully protected in that country.

\subsection{Legal acquisition findings}

The second main condition for authorizing the export of specimens of CITES Appendiceslisted species is the certification by the MA of the State of export that the specimen was

\footnotetext{
19 The guidelines only mention high seas, and the glossary attached to these guidelines defines high seas as "[a]reas outside of the jurisdiction of any State (also international waters, or transboundary waters). Fisheries on the high seas are managed by regional fisheries management bodies".

${ }^{20}$ Article IV(7) states, "[Introduction from the Sea] Certificates referred to in paragraph 6 of this Article may be granted on the advice of a Scientific Authority, in consultation with other national scientific authorities or, when appropriate, international scientific authorities, in respect of periods not exceeding one year for total numbers of specimens to be introduced in such periods".
} 
not obtained in contravention of that State's laws for the protection of fauna and flora (see Annex A) (CITES, 1973, Articles III (2)(b), IV (2)(b) and V (2)(a)). This certification is commonly referred to as a legal acquisition finding (LAF). This requirement is common to the trading of species listed in all three CITES Appendices and consists of the MA satisfying itself that the specimen was not obtained in contravention of the laws and regulations of that State. The CITES Model Law defines a LAF as a

finding by the Management Authority of the State of export determining whether the specimens were acquired consistent with national laws. The applicant is responsible for providing sufficient information to show that the specimen was legally acquired (CITES, n.d-g).

The making of LAFs and respective verification and related procedures are the responsibility of each party. CoP18 adopted a new Resolution Conf. 18.7 containing recommendations on guiding principles for verifying the LAF of specimens to be exported, guidance for making LAFs as well as additional circumstances, as specified in this resolution, requiring the verification of LAFs or other legal findings (CITES, 2019c).

The LAF amounts to or constitutes a determination of the legality of the fish species being internationally traded, and in this respect can play an important role in the efforts to combat IUU fishing. The making of a LAF could be facilitated by States' port authorities, together with the information collected and verified by port inspectors (e.g. catch certificates), to determine whether a foreign vessel attempting to enter port is engaged in illegal fishing of CITES-listed aquatic species. The Agreement on Port State Measures to Prevent, Deter and Eliminate Illegal Unreported and Unregulated Fishing (PSMA, 2009) requires its parties to ensure that port State inspectors carry out certain specified functions as a minimum standard. These include reviewing all relevant documentation and records held on board, expressly mentioning "documents required pursuant to [CITES]" (PSMA, 2009, Annex B(d)). There are currently 66 parties to the PSMA, including the EU and its 27 Member States (thus a total of 92 States participating in implementing the PSMA) (FAO, n.d-g). This accounts for almost half of the parties to CITES. Consequently, the obligation to produce a CITES document for international trade transactions in CITES-listed aquatic species could ensure that lawful trade is observed by a larger number of countries, including non-parties to the PSMA that are parties to CITES.

Where a Silky shark (Carcharhinus falciformis) specimen, for instance, is harvested on the high seas by a vessel flying the flag of one State which subsequently attempts to land the catch in a port State where these States are parties to both CITES and the PSMA, then the flag State would be required to issue a CITES Export Permit. The port State, would, in turn, have the power to deny the use of its port for such landing, in accordance with the requirements of the PSMA, Article 11(1). The making of both an NDF and a LAF could be facilitated by data-sharing among the 183 CITES parties, almost half of which, as aforementioned, are parties to the PSMA. This includes States that are vicariously bound to the PSMA as members of the EU. Data-sharing could also be facilitated by non-parties and other territories that are members of, or participate in, regional fisheries management organizations or arrangements (RFMO/As) as Cooperating Non-Contracting Parties (CNCPs) or Cooperating Non-Members (CNMs) (Molenaar, 2019).

This interaction contributes to the making of a LAF (i.e. whether or not the CITES-listed species was legally caught), ${ }^{21}$ or of a NDF (i.e. whether or not the trade of such species could be detrimental or not to its survival ultimately improving the sustainable utilization of fisheries resources (see Table 4 herein).

\footnotetext{
${ }^{21}$ For a better understanding of the scope of legality under CITES, see Korwin et al., 2019.
} 


\subsection{Voluntary export quotas}

In addition to the making of NDFs, the SA is responsible for monitoring activities prior to the granting of permits for exports of Appendix II-listed species as well as for monitoring the actual export of such species. Fulfilment of these responsibilities can be partially ensured by means of the SA's advice to the competent MA in undertaking sustainable measures to "limit the grant of export permits for specimens of that species" (CITES, 1973, Article IV (3)). While CITES, Article IV(3) does not expressly refer to "export quotas", it does support the establishment of voluntary export quotas by the parties. More specific guidelines on voluntary export quotas are provided by Resolution Conf. 14.7 (Rev. CoP15) on the "Management of nationally established export quotas" (CITES, 2007b). The Annex to the Resolution contains guidelines relating to the establishment, management, monitoring and trade reporting of national export quotas of Appendix II-listed species, and also to communication of such information to the CITES Secretariat (CITES, 2007b). These guidelines cover, amongst other things, the need for the relevant export quota to be based on the relevant NDF and the possibility of establishing separate quotas for specimens with different sources. They also assert that it is the responsibility of the respective party to monitor the usage of export quotas to ensure they are not exceeded. It also states that parties should inform the CITES Secretariat about the adopted export quotas and respective revisions of their quotas (CITES, 2007b, Annex).

With respect to export quotas for Appendix 1-listed species, the parties have agreed on procedures for establishing new quotas or amending those already in existence. Parties are expected to submit their respective proposals to the Secretariat not less than 150 days prior to the CoP, and to ensure that such proposals contain supporting information including scientificbased data (CITES, 1994c). ${ }^{22}$ Appendix-II species have been the subject of voluntary national export quotas (see examples in Table 2).

\begin{tabular}{|c|c|c|c|}
\hline \multicolumn{4}{|c|}{$\begin{array}{c}\text { Table } 2 \\
\text { Examples of CITES Appendix II-listed fish species subject to voluntary national export quotas }\end{array}$} \\
\hline Countries & Species & Voluntary Export Quota & Year of inclusion \\
\hline Tunisia & European eel & $90000 \mathrm{~kg}$ quota wild-taken & 2019 \\
\hline $\begin{array}{l}\text { Democratic Republic } \\
\text { of Congo }\end{array}$ & African blind barb & 70 quota live & 2018 \\
\hline Jamaica & Queen Conch & $450000 \mathrm{~kg}$ & 2018 \\
\hline Indonesia & Humphead wrasse & 2000 quota live & 2016 \\
\hline Indonesia & Barbour's seahorse & 8000 hds quota live & 2016 \\
\hline Azerbaijan & Russian sturgeon & zero quota caviar and meat & $2017 / 2018$ \\
\hline China & Japanese sturgeon & zero quota caviar and meat & 2017 \\
\hline
\end{tabular}

22 Please note that the operationalization of these proceedings is very exceptional and concern no marine species. 
The establishment of voluntary export quotas for aquatic species may be authorized by fisheries legislation with respect to certain Appendix II-listed species such as giant clams and sea cucumber. For example, in Tonga, the Fisheries Management (Conservation) Regulations 2008 provide for a full ban on the export of giant clam meat for commercial purposes. ${ }^{23}$ In Vanuatu, the Fisheries Regulations 2009 establish an annual quota allocation of 26 tonnes for sea cucumber that can be exported. ${ }^{24}$ Some fisheries legislation can impose even stricter provisions than those in CITES, imposing a prohibition on the export of rare and endangered fish species, including CITES-listed species. An example of this is the United Republic of Tanzania's Fisheries (Amendment) Regulations 2009, which lists in one of its schedule species (including species of sharks and rays) recognized as being globally or regionally endangered, prohibiting the fishing, possessing, processing, offering for sale, marketing or exporting of such species. ${ }^{25}$

These examples demonstrate how countries have put in place additional non-binding requirements and have incorporated export bans or quotas in their national fisheries legal frameworks. A country's CITES authorities, hence, may also rely on these fisheries requirements in support of regulating export quotas of CITES-listed species.

\subsection{Requirements for the transport of live specimens}

According to CITES, "specimen" means "any animal or plant, whether alive or dead" (CITES, 1973, Article I (b)(i)). CITES provides particular emphasis upon trade involving "living specimens". A general obligation is imposed on all parties to ensure that "all living specimens, during any period of transit, holding or shipment, are properly cared for so as to minimize risks of injury, damage to health or cruel treatment" (CITES, 1973, Article VIII (3)). This same duty is specifically provided with respect to the preparation and shipment of living specimens by the MA of the State of export, re-export and of introduction from the sea in those trade activities of living specimens listed in Appendices I and II, as well as by the MA of the State of export in such trade activity of Appendix III living specimens (see Annex A) (CITES, 1973, Articles III (2)(c) $(4)(b)(5)(b), I V(2)(c)(5)(b)(6)(b)$ and V (2)(b)).

For Appendix I-listed species, another type of special treatment that CITES provides in relation to living specimens focuses on ensuring that the proposed recipient of a living specimen is "suitably equipped to house and care for it". This is a requirement for the SA of the State of import or the MA of the State of introduction (CITES, 1973, Article III (2)(b) and (5)(b)). With respect to confiscation of living specimens, CITES requires that such specimens are entrusted to a MA of the State of confiscation and requires this MA to consult with the State of export, then return the specimen to that State at the expense of the latter, or to a rescue centre designated by the MA to look after the welfare of living specimens, or such other place as advised by the MA (CITES, 1973, Article VIII (4)(5)). CITES also includes, among the functions of the Secretariat, the undertaking of scientific and technical studies on standards for the preparation and shipment of living specimens in accordance with programmes authorized by CoPs (CITES, 1973, Article XII (2)(c)).

The CITES guidelines for the transport and preparation for shipment of live wild animals and plants are based on the Live Animals Regulations of the International Air Transportation

\footnotetext{
${ }^{23}$ Tonga. Fisheries Management (Conservation) Regulations of 2008, Section 20(3)

${ }^{24}$ Vanuatu. Fisheries Regulations Order of 2009, Section 61

25 United Republic of Tanzania. Fisheries Regulations G.N. No. 308 of 2009, Section 67 and Schedule 3(c).
} 
Association (IATA). ${ }^{26}$ They were developed in the early 1980s and supplemented in 2013 by guidelines on the non-air transport of live wild animals and plants (CITES, 2013b). Guidelines for the general care and loading of fish species are provided therein, advocating that fish tanks designed to be transported by road are designed so that their lids do not completely seal thus enabling the release of excess gases without compromising water loss (CITES, 2013b, Section 4.2). Parties are encouraged, amongst other things, to take suitable measures to promote full and effective use by MAs of these regulations and guidelines, and to bring them to the attention of exporters, importers, transport companies, carriers, freight forwarders, inspection authorities, international organizations and conferences competent to regulate conditions of carriage by air, land, sea or inland waterways (CITES, 1997).

These CITES requirements and guidelines may not, in principle, be relevant to most commercially exploited and managed aquatic species, but it is important to note that they could play a role in the fisheries sector with respect to the transport of certain aquatic species, e.g. for live reef food fish trade, aquariums or aquaculture. Relevant CITES-listed Appendix II examples are the Humphead wrasse (Cheilinus undulates) in the live reef food fish trade and the seahorse (Hippocampus) as well as certain species of dolphins (Delphinidae), which are often subject to international trade for use in aquariums. A non-CITES listed example, which is nevertheless significant to the fisheries sector, is the wild bluefin tuna species (Thunnus thynnus) in capture-based aquaculture (Ottolenghi, 2008). During transportation, which is conducted by towing cages and tugboats from the marine fishing catch area to on-growing or farm sites, these species could suffer negative impacts that may threaten their survival (Ottolenghi, 2008, pp. 174-175). ${ }^{27}$ Other examples are fish invertebrates such as live corals for ornamental purposes (e.g. in public aquariums), but the risk of mortality in such cases seem to be minimal (Delbeek, 2008). Regardless of the level of risk that species specimens face, the approach should always be precautionary. This makes it important to take into account the provisions of CITES regarding transport of live specimens by ensuring that live fish and other CITES-listed marine species are properly cared for in any circumstances where they undergo live transportation.

\subsection{Options for the disposal of illegally traded and confiscated fish specimens}

CITES requires parties to apply sanctions and take appropriate enforcement measures against actors trading in specimens of CITES-listed species in contravention of its provisions, including the failure to prohibit trade in illegally acquired specimens. Sanctions may include imposing penalties against violators who trade in, or are in possession of, such specimens, or both and to provide for the confiscation of such specimens or their return to the State of export (CITES, 1973, Article VIII (1)). These CITES sanctions and enforcement measures are similar, to a certain extent, with requirements of the FAO guidelines for catch documentation schemes (CDS) and the CDS adopted by certain RFBs. For example, a conservation and management measure recently adopted by the Commission for the Conservation of Antarctic Marine Living Resources (CCAMLR) on CDS for toothfish (Dissostichus) requires the contracting parties to ensure that the sale of confiscated toothfish does not result in financial benefits accruing to

\footnotetext{
${ }^{26}$ See IATA's Live Animal Regulations (IATA, n.d.). However, CITES appears to be deferring to LAT for compliance with the requirements under the Convention (CITES, 1997).

27 Though it has been noted that the mortality rate would normally be low in these situations of transport, the rare cases where all fish have died should not be ignored.
} 
those responsible for, or benefiting from, the activities that led to the confiscation of the catch (CCAMLR, 2018; CITES, 2016a, paragraph 2(b)).

The CoP has adopted Resolution Conf. 17.8, which recommends the use of the CITES guidelines for: (i) disposal of confiscated live animals; (ii) disposal of confiscated live plants and (iii) development of an action plan on seized and/or confiscated live specimens (CITES, 2016a). A Working Group comprising parties and non-governmental organizations (NGOs), among other things, highlighted the financial challenges of recovery of seizure costs and disposal, lack of official funding and facilities for the confiscated live specimens, as well as constraints for the safe and appropriate custody of live animals until final disposition (CITES, 2018a).

\section{Other CITES implementation activities}

\subsection{CITES partnerships on biodiversity conservation and wildlife crime}

The Biodiversity Liaison Group (BLG) is made up of the heads of the Secretariats of various relevant international regimes including: CITES; the Convention on Biological Diversity (CBD); the Convention on the Conservation of Migratory Species and Wild Animals (CMS) and the International Convention for the Regulation of Whaling (ICRW). The International Whaling Commission constituted by the latter recently joined the group in 2017. ${ }^{28}$ Since 2004, members of the BLG have been meeting to share ongoing developments and outcomes of the relevant regulatory regimes. In relation to the $C B D$, for example, the Strategic Plan on Biodiversity 20102020 and Aichi Biodiversity Targets (ABTs), in particular ABT6, aim at applying the ecosystem approach to fisheries (EAF) in order to avoid overfishing, as well as seeking to ensure that there are recovery plans and measures for all depleted species, and to ensure that fisheries have no significant impacts on threatened species and vulnerable ecosystems, and, to ensure that the impacts of fisheries on stocks, species and ecosystems are within safe ecological limits (CITES, n.d-a).

The CMS interaction with CITES has fostered regional collaboration with respect to certain marine species. These include marine turtles located close to the Atlantic coast of Africa, the Indian Ocean, Southeast Asia and the Pacific Ocean; whale sharks (Rhincodon typus) of Southeast Asia; the great white shark (Carcharodon carcharias) and sturgeons (Acipenseriformes) (CITES, 2004b).

Launched in 2010, the International Consortium on Combating Wildlife Crime (ICCWC), which comprises the CITES Secretariat; the International Criminal Police Organization (INTERPOL); the UN Office on Drugs and Crime (UNODC); the World Bank and the World Customs Organization (WCO), has supported efforts to strengthen the criminal justice system and provide coordinated support at national, regional and international level to combat wildlife crime in support of the implementation of CITES. The ICCWC Strategic Programme 2016-2020 outlines various activities, some of which are particularly relevant for legal implementation of CITES. These include support for regional law enforcement cooperation and support and initiatives for regional law enforcement interventions (ICCWC, 2016b). The ICCWC has developed, and has been implementing, its Wildlife and Forest Crime Analytic Toolkit. This covers all wild

\footnotetext{
${ }^{28}$ The other regimes are the International Treaty on Plant Genetic Resources for Food and Agriculture (ITPGRFA) 2001, the Convention on Wetlands of International Importance especially as Waterfowl Habitat (Ramsar Convention) 1971, the Convention concerning the Protection of the World Cultural and Natural Heritage (WHC) 1972, and the International Plant Protection Convention (IPPC) 1951. See CBD, 2020.
} 
fauna and flora, including fish, and aims to guide relevant government officials in assessing administrative, preventive and criminal justice responses to wildlife and forest crime, other related offences, as well as identifying the actors involved in such offending in any given country (UNODC, 2012). As of September 2018, the implementation of the toolkit has been undertaken in a number of countries including: Bangladesh; Botswana; Gabon; Madagascar; Mexico; Mozambique; Peru; United Republic of Tanzania; Uganda and Viet Nam (ICCWC, 2018; CITES, 2019a).

A complementary tool is the ICCWC Indicator Framework for Combating Wildlife and Forest Crime. This supports the parties in assessing their national law enforcement response to wildlife and forest crime and enables them to independently monitor performance over time in order to identify any changes in the effectiveness of ongoing law enforcement responses. This is based on a set of 50 indicators that refer to eight outcomes corresponding to an effective law enforcement response (ICCWC, 2016a). The ICCWC also provides coordination support to national wildlife enforcement agencies and to a number of regional and sub-regional wildlife enforcement networks. It also supports a number of activities and operations ranging from species-specific activities to regional meetings and Task Forces, to regional and global operations such as the Thunder-series (CITES, 2019a; CITES 2018d).

It is important that the institutions involved in ICCWC are also aware of the CITES-FAO cooperation, and that there may be other opportunities to integrate and contribute to the development and implementation of projects in a cost-effective way.

\subsection{FAO's technical assistance, tools, guidelines and plans of action}

FAO has been contributing directly and indirectly to the implementation of CITES for over two decades. It has been playing a strategic role, mainly through technical assistance on matters concerning commercially exploited and managed aquatic species, capacity-building in developing countries, as well as facilitating discussions to clarify the relationship between FAO and CITES, and leading efforts aimed at resolving certain legal issues such as operationalizing IFS. Recommendations from FAO concerning commercially exploited and managed aquatic species were adopted in revised versions of the listing criteria and procedure for evaluating proposals to amend CITES Appendices I or II. This technical assistance has contributed to the listing of Oceanic whitetip shark, Porbeagle shark, Scalloped, Great, and Smooth- hammerhead sharks and all manta rays in Appendix II at CoP16 and of Silky and Thresher sharks and devil rays in Appendix II at CoP17.

Since 2004, an FAO Ad Hoc Expert Advisory Panel convenes prior to CITES CoPs in order to review and undertake assessments of proposals for amending Appendices I and II. ${ }^{29}$ Other CITES-related activities of FAO's Fisheries and Aquaculture Department worthy of mention are the creation and maintenance of GLOBEFISH, an online database which collects and provides information and analysis of international fish trade and markets (FAO, n.d-e), and the Fisheries Global Information System (FGIS) for integrating information sources (FAO, n.d-c).

FAO's work on capacity-building and training, especially in developing countries, has contributed to the addressing of challenges in implementing CITES requirements. This has

\footnotetext{
${ }^{29}$ The first Panel assessed proposals submitted to CoP13 in 2004 and the most recent Panel examined proposals to CoP18 for the inclusion of aquatic species in Appendix II, such as shortfin- and longfin- mako shark species, blackchin- and Sharpnose- guitarfish and white-spotted wedgefishes. See FAO, n.d-b. For more information on the latest Panel, see FAO, 2019b.
} 
included fostering improved assessments and management plans relating to certain marine species such as: precious corals; sea cucumbers; Humphead wrasse; sharks and queen conch. ${ }^{30}$ The FAO's collaboration with other institutional partners, including CITES bodies, has resulted in the development of a number of tools relevant to marine species assessment and other functions. These include: iSharkFin, which is a software designed to facilitate the identification of shark species by users without formal taxonomic training (e.g. port inspectors, customs agents, fish traders) based on a photograph of shark fin shapes (FAO, n.d-f); FishFinder, which is a species identification and data collection programme for marine organisms of actual and potential interest to fisheries (FAO, n.d-d) and the Bycatch Management Information System (BMIS), which is focused on mitigating bycatch in oceanic tuna and billfish fisheries from longline and purse seine fishing, and on the management of such species (BMIS, n.d).

Additionally, the non-legally-binding FAO International Plans of Action (IPOAs) for the Conservation and Management of Sharks (IPOA-Sharks) and for Reducing Incidental Catch of Seabirds in Longline Fisheries (IPOA-Seabirds) are designed to contribute to the protection of sharks and seabirds from the impacts of fishing and other practices to ensure that appropriate fisheries management and conservation measures are in place to achieve the intended objectives (FAO, 2020b). ${ }^{31}$ The relevant FAO instruments that are legally-binding and those which have a non-legally-binding nature, all which contribute to the implementation of CITES are listed in Table 3.

\begin{tabular}{|l|l|}
\hline & \multicolumn{1}{|c|}{$\begin{array}{c}\text { Table } 3 \\
\text { Select FAO's instruments and guiding documents relevant to CITES implementation }\end{array}$} \\
\hline 2019 & $\begin{array}{l}\text { Step-wise Guide for the Implementation of International Legal and Policy Instruments related to Deep } \\
\text { Sea Fisheries and Biodiversity Conservation in ABNJ }\end{array}$ \\
\hline 2019 & Voluntary Guidelines on the Marking of Fishing Gear \\
\hline 2017 & Voluntary Guidelines for Catch Documentation Schemes \\
\hline 2016 & How-to Guide on Legislating for an Ecosystem Approach to Fisheries \\
\hline 2014 & Voluntary Guidelines for Securing Sustainable Small-scale fisheries ${ }^{33}$ \\
\hline 2010 & International Guidelines on Bycatch Management and Reduction of Discards \\
\hline 2010 & $\begin{array}{l}\text { Simplified Guidelines for putting into practice an ecosystem approach to managing sea cucumber } \\
\text { fisheries }{ }^{34}\end{array}$ \\
\hline 2009 & $\begin{array}{l}\text { Agreement on Port State Measures to Prevent, Deter and Eliminate Illegal, Unreported and Unregulated } \\
\text { Fishing }\end{array}$ \\
\hline
\end{tabular}

\footnotetext{
${ }^{30}$ See FAO activities in relation to CITES and commercially-exploited aquatic species (FAO, n.d-a).

31 The IPOA-Sharks, a collaboration between FAO, CITES, the EU, the Government of Japan and the National Oceanographic and Atmospheric Administration (NOAA) of the United States of America, has resulted in the development of a database of measures on conservation and management of sharks.

${ }^{32}$ Role in preventing trade in products of IUU fishing.

${ }^{33}$ Note that small-scale fisheries may harvest CITES-listed shark species and their products may enter into international trade.

${ }^{34}$ Note that Ecuador has listed a species of sea cucumber (Isostichopus fuscus) in Appendix III and certain species of sea cucumber were recently listed in Appendix II.
} 


\section{Table 3 (cont.)}

\begin{tabular}{|c|c|}
\hline 2009 & Technical Guidelines on Responsible Fish Trade \\
\hline 2008 & Manual for monitoring and managing queen conch fisheries ${ }^{35}$ \\
\hline 2007 & Legislative Drafting Guide: A Practitioner's View \\
\hline 2007 & Stock Assessment Approach for the Napoleon Fish, Cheilinus undulatus ${ }^{36}$ \\
\hline 2003 & Ecosystem Approach to Fisheries Guidelines \\
\hline 2003 & Strategy for improving the information on status and trends of capture fisheries \\
\hline 2001 & $\begin{array}{l}\text { International Plan of Action to Prevent, Deter and Eliminate Illegal, Unreported and Unregulated } \\
\text { Fishing }\end{array}$ \\
\hline 2000 & International Plan of Action for Reducing Incidental Catch of Seabirds in Longline Fisheries \\
\hline 2000 & International Plan of Action for the Conservation and Management of Sharks \\
\hline 2000 & International Plan of Action for the Management of Fishing Capacity \\
\hline 1995 & Code of Conduct for Responsible Fisheries ${ }^{37}$ \\
\hline 1993 & $\begin{array}{l}\text { Agreement to Promote Compliance with International Conservation and Management Measures by } \\
\text { Fishing Vessels on the High Seas }\end{array}$ \\
\hline
\end{tabular}

\subsection{Potential contributions of Regional Fishery Bodies to CITES implementation}

According to the United Nations Convention on the Law of the Sea (LOSC, 1982), States have the duty to maintain or restore marine living resources, including dependent or associated species, in their EEZs and in the high seas. This should be at levels which can produce the maximum sustainable yield, as qualified by relevant environmental and economic factors, including the economic needs of coastal fishing communities and the special requirements of developing States (LOSC, 1982, Articles 61 (3) and 119 (1)). States also have the duty to contribute and exchange available scientific information, catch and fishing efforts statistics and other relevant data either directly or through competent international organizations such as RFBs (LOSC, 1982, Articles 61, 118 and119). Cooperation on transboundary fish stocks is also a mandated duty under the LOSC (LOSC, 1982, Articles 63 and 64). The numerous RFBs, which include RFMO/As and regional fishery advisory bodies (RFABs), operate to facilitate fulfilment of these requirements. Their role in contributing to CITES implementation is promising, especially in respect of their support to the making of NDFs for shared highly migratory species, including sharks, that were recently included in CITES Appendix II (CITES, 2002C).

\footnotetext{
${ }^{35}$ Requirements for responsible management of this Caribbean species listed in Appendix II.

${ }^{36}$ Role in assisting range States to address NDF requirements for this Appendix II species.

${ }^{37}$ Article 11.2.9 calls upon States to cooperate in complying with relevant international agreements regulating trade in endangered species.
} 
The IPOA-IUU highlights the importance of internationally agreed market-related measures through the assistance of RFMO/As in the development and adoption of trade documentation and certification schemes (FAO, 2001, Paragraphs 65-76). CITES parties have recognized the importance of all States, including those not members of or parties to RFBs, cooperating in establishing and implementing conservation and management measures. For example, the CoP18 recently revised Resolution Conf. 12.4 on Cooperation between CITES and the [CCAMLR] regarding trade in toothfish (Dissostichus spp.). This recommends that the parties, amongst other things,

adopt the [aforementioned] Dissostichus Catch Document used by CCAMLR for Dissostichus spp. and implement requirements for verification in all cases where specimens of these species are introduced into or exported from or transit through the territory under their jurisdiction (CITES, 2002b). ${ }^{38}$

The CoP also welcomed the work of CCAMLR in combatting IUU fishing and urged the parties to study the issue of trade in specimens of Patagonian toothfish and Antarctic toothfish and to cooperate with the CCAMLR Secretariat in data collection.

A list containing RFMO/As' selected measures, including CDS, which relate to CITES-listed protected species (mainly sharks), and which contribute to the implementation of CITES is provided in Annex C.1.

In relation to RFABs, the Western Central Atlantic Fishery Commission (WECAFC) has involved the participation of representatives from CITES and other regional partner institutions in the associated Working Groups on shark conservation and management as well as on Queen conch (FAO, 2018b; FAO, 2019c). Their post-meeting reports provide recommendations, some of which can be found in Annex C.2, containing a list of RFABs' selected recommendations.

Since 2013, with more and more species of sharks and rays (Elasmobranchii) being caught as targeted catch or bycatch in the areas of competence of RFBs, in particular since CITES CoP16, the CITES Secretariat has undertaken multiple activities to increase collaboration with RFBs, many of which have taken place under the framework of the 2013-2017 and 2017-2020 EU funded capacity-building projects (CITES, n.d-j). These have included: capacity-building to improve the ability of West African countries to improve shark data collection and research undertaken jointly with the International Commission on the Conservation of Atlantic Tuna (ICCAT) in 2016 (CITES, 2016b); a data compilation for two species of shark organized in collaboration with the Indian Ocean Tuna Commission (IOTC) in 2017 (CITES, 2016c; IOTC, 2017); and support for data collection and the making of NDFs with the Southeast Asian Fisheries Development Center (SEAFDEC) 2015-2016 (CITES, 2016d), which was followed up with more specific support in 2018-2020. In early 2017, the CITES Secretariat convened a meeting with representatives from FAO, ICCAT, IOTC, SEAFDEC, WECAFC and the Inter-American Tropical Tuna Commission (IATTC) to take stock of successes and to discuss lessons learned during the implementation of their collaborative activities. Participants also exchanged information and ideas on a range of issues including: work programmes and priorities for the next few years; scientific management of sharks and rays; the collection, analysis and exchange of data; and how to further improve inter-agency communication (CITES, 2017b). The CITES Secretariat also provided written input into the joint tuna-RFMO meeting that took place 16-18 December 2019 in Porto, Portugal (ICCAT, 2019).

\footnotetext{
38 This attention given to Dissostichus spp toothfish stemmed from proposal by Australia for the listing of this species on Appendix III, but the respective genus remains absent in CITES appendices.
} 
These collaborative joint activities helped to demonstrate that the numerous measures adopted by RFBs concerning certain CITES-listed species (mainly sharks) and those addressing IUU fishing can contribute to the implementation of CITES. One very important role that has also been reflected in the CITES Sharks Resolution that of regional organizations, such as RFBs, in compiling and sharing stock status information and assessments, and any other relevant data, on a regional basis to inform the making of NDFs. ${ }^{39}$ Another contribution is that of informing the relevant national authorities (e.g. those competent for CITES, fisheries, port, customs issues) that the CITES-listed species have been legally caught, or assisting in the evaluation of compliance with the applicable RFB measure(s) to support the making of a LAF. The ways in which RFB measures should be taken into account in the making of LAF has been discussed by the CITES Standing Committee (CITES, 2018c), but will be further discussed along with other considerations post-CoP18. ${ }^{40}$ However, cooperation among the parties or by members of the RFBs with CITES depends on efficient national legal and institutional frameworks as regards the CITES regime. The CITES Sharks Resolution specifically encourages such coordination (CITES, 2002c, Paragraph 6). The guide proposed in the present document will assist countries towards achieving this principal objective.

\subsection{Fisheries measures in the CITES regime and vice versa}

This study has demonstrated a number of practices by which the fisheries sector and the CITES regime can interact and drive forward meaningful collaboration. These interactions already occur, but they need to be consistent, coherent and complementary. It is important that the relevant actors engaged in CITES implementation and in fisheries management are fully aware of each other's activities in order to ensure the coherent implementation of CITES in the fisheries sector.

The influence of CITES and of the fisheries sector can also have very similar effects in relation to the conservation of marine resources. There are cases where a non-party to CITES is a member of an RFB (e.g. Kiribati, the Federated States of Micronesia). Although CITES requirements do not apply to these States, the conservation and management measures adopted by the RFBs to which they are affiliated serve to strengthen their efforts in conserving, within their jurisdiction, aquatic species that may be included in the CITES Appendices. The same rationale applies to non-members of RFBs which may be party to both CITES and the PSMA (e.g. Djibouti), ensuring that these countries are bound by requirements on conserving and managing the fishery resources over which RFBs have competence.

As shown therefore, the different approaches adopted by CITES and the fisheries sector can operate, in practice, in areas of convergence with a view to achieving the overall objectives of ensuring sustainability in fisheries, a responsible, legal and sustainable fisheries trade and SDG14. Table 4 provides a synthesis of the main measures or tools adopted by CITES and the fisheries sector which can, if not already doing so, contribute to these actors supporting and strengthening each other.

\footnotetext{
${ }^{39}$ Compare with Paragraph 5 (CITES, 2002c). In practice, however, according to information obtained in the CITES Expert Workshop and follow-up activities, few contracting parties seem to provide adequate catch data to RFBs, especially on bycatch species.

${ }^{40}$ Compare with CITES Decision 18.224
} 
Table 4

Correlations between outputs of the CITES regime and fisheries management

\begin{tabular}{|c|c|}
\hline \multicolumn{2}{|c|}{ Outputs } \\
\hline CITES Regime & $\rightarrow$ Fisheries Management \\
\hline - MA / SA & - FA \\
\hline - NDF (SA) & - Stock assessments (FA or RFB) \\
\hline - LAF (MA) & $\begin{array}{l}\text { - CDS, certificate or fishing authorizations e.g. } \\
\text { licences, permits or quotas (FA or RFB) }\end{array}$ \\
\hline $\begin{array}{l}\text { - Compliance with national legal frameworks that } \\
\text { implement CITES }\end{array}$ & $\begin{array}{l}\text { - Compliance with national fisheries legal } \\
\text { frameworks, including those implementing RFB } \\
\text { measures }\end{array}$ \\
\hline $\begin{array}{l}\text { - Confiscation of specimens (MA or Enforcement } \\
\text { Authority) }\end{array}$ & $\begin{array}{l}\text { - Confiscation, seizure or forfeiture of aquatic } \\
\text { species (FA or Enforcement Authority) }\end{array}$ \\
\hline - Voluntary export quota of CITES-listed species & $\begin{array}{l}\text { - Ban or limit on the catch of certain aquatic } \\
\text { species, which may include CITES-listed species }\end{array}$ \\
\hline
\end{tabular}

\section{Concluding remarks}

As a consequence of the increasing number of commercially exploited and managed aquatic species listed in CITES Appendix II, and the growing percentage of fish and fish-derived products being exported, the implementation of CITES requires particular attention from the fisheries sector. An enhanced implementation of CITES through national fisheries legal frameworks is needed. Advances towards achieving a more responsible fisheries trade can be realized if the appropriate legal frameworks are in place, particularly where the international trade involves species that are threatened or potentially threatened with extinction.

This study has highlighted and discussed a number of principal relevant issues concerning the interaction between the CITES regime and the fisheries sector. It has explored opportunities worthy of pursuit that could potentially contribute to the enhanced implementation of CITES and other primary international fisheries instruments, thus increasing the likelihood of attaining the overarching objective of sustainable utilization of resources, including species, biodiversity and ecosystems, and SDG14.

Ensuring responsible and sustainable trade of aquatic species listed in the CITES Appendices requires continued improvements in the implementation of CITES and related fisheries instruments. This will involve exploring new avenues and pursuing options which contribute to avoiding extinction or over-exploitation of fish species and harm or destruction to associated 
biodiversity and ecosystems. ${ }^{41}$ The implementation of CITES through national fisheries legal frameworks is an option that should be considered by States with large fisheries interests. Implementation can be facilitated in particular, by the MA and SA of the relevant party to CITES, as well as the fisheries authorities and other stakeholders of the fisheries sector such as the authorities responsible for port, customs and maritime issues. This collaboration in implementing CITES and related fisheries instruments is consistent with the call for integration of biodiversity considerations and conservation into fisheries management (Kuemlangan et al., 2014).

Not only can national fisheries legal frameworks contribute to CITES implementation and beyond, bringing biodiversity conservation and an ecosystem approach to the fisheries sector into the mainstream, but national fisheries legal frameworks can also be improved by adopting certain approaches and measures that are being utilized by CITES parties for the implementation of the Convention. The guide will demonstrate how such improvement can be achieved.

${ }^{41}$ Please note that lists are periodically updated, pursuant to determinations at the most recent CoP. The most recent list can be found at CITES, n.d-b. 


\section{References}

\section{Literature}

CECAF. 2016. Report of the Fisheries Management in the CECAF region: fisheries management recommendations and their utilization for fisheries management. CECAF/XXI/2016/4.

CITES. 2012. Joint Session of the 26th Meeting of the Animals Committee and 20th Meeting of the Plants Committee, Draft Guidance on the Making of Non-Detriment Findings (22-24 March 2012, Dublin, Ireland).

CITES. 2015. AC28 Doc. 15, Annex 2. Non-Detriment Findings and Trade Management for Tortoises and Freshwater Turtles - a guide for CITES Scientific and Management Authorities.

CITES. 2017. SC69 Doc. 36. Introduction from the sea: Report of the Secretariat, 69th Meeting of the Standing Committee. Geneva, Switzerland, 27 Nov. - 1 Dec. 2017.

CITES. 2019a. CoP18 Inf. 45 International Consortium on Combatting Wildlife Crime (ICCWC). Geneva, Switzerland, 17-28 August 2019.

CITES. 2018a. SC70 Doc. 32. Disposal of Confiscated Specimens: Report of the Working Group, 70th Meeting of the Standing Committee. Rosa Khutor, Sochi, Russian Federation, 1-5 October 2018.

CITES. 2018b. SC70 Doc. 34. Introduction from the sea: Report of the Secretariat, 70th Meeting of the Standing Committee. Rosa Khutor, Sochi, Russian Federation, 1-5 October 2018.

CITES. 2018c. SC70 Doc. 48.1. Specific matters: Sharks and rays (Elasmobranchii spp.) Report of the Working Group, 70th Meeting of the Standing Committee. Rosa Khutor, Sochi, Russian Federation, 1-5 October 2018.

Clarke, S. Manarangi-Trott, L. \& Brouwer, S. 2014. Issues for t-RFMOs in relation to the listing of shark and ray species by the Convention on International Trade in Endangered Species (CITES). Paper presented at the Tenth Regular Session of the WCPFC in Majuro, Republic of the Marshall Islands, 6-14 August 2014, WCPFC=SC10-2014/EB-IP-05, 18p.

Delbeek, J. 2008. Collecting and shipping live coral: techniques, tips and headaches. In: Leewis, R.J. \& Janse, M. (Eds.) Advances in Coral Husbandry in Public Aquariums. Public Aquarium Husbandry Series, Vol. 2, pp. 363-373.

Dent, F. \& Clarke, S. 2015. State of the global market for shark products. FAO Fisheries and Aquaculture Technical Paper No. 590. Rome, FAO. 187p.

FAO. 1995. Report of the twenty-first session of the Committee on Fisheries. Rome, 10-13 March 1995. FAO Fisheries Report No. 524. Rome. 61p.

FAO. 1997. Fishery Resources Division and Fishery Policy and Planning Division. Fisheries management. FAO Technical Guidelines for Responsible Fisheries. No. 4. Rome. 82p.

FAO. 2003. The Ecosystem Approach to Fisheries. FAO Technical Guidelines for Responsible Fisheries. No. 4, Suppl. 2. Rome. 112 p. 
FAO. 2009. Responsible Fish Trade. FAO Technical Guidelines for Responsible Fisheries. No. 11. Rome. 23p.

FAO. 2016. A How-to Guide on legislating for an ecosystem approach to fisheries. In: FAO EAFNansen project report No. 27, Rome. 56p.

FAO. 2018a. The State of World Fisheries and Aquaculture 2018 - Meeting the sustainable development goals. Rome, FAO. 210p.

FAO. 2018b. Western Central Atlantic Fishery Commission. Report of the First meeting of the WECAFCIOSPESCA/CRFM/CITES/CFMC working group on shark conservation and management, Barbados, 17-19 October 2017. FAO Fisheries and Aquaculture Report No. 1 192. Bridgetown, Barbados.

FAO. 2019a. Report of the First Expert Workshop for the Assessment of Proposals on Implementing the Convention on International Trade in Endangered Species of Wild Fauna and Flora (CITES) through Fisheries Legal Frameworks, Rome, Italy, 6-8 May 2019. FAO Fisheries and Aquaculture Report No. 1 276. Rome.

FAO. 2019b. Report of the Sixth FAO Expert Advisory Panel for the Assessment of Proposals to Amend Appendices I and II of CITES Concerning Commercially Exploited Aquatic Species, Rome, 21-25 January 2019. FAO Fisheries and Aquaculture Report No. 1255 . Rome.

FAO. 2019c. Western Central Atlantic Fishery Commission. Report of the Third meeting of the CFMCIOSPESCA/WECAFC/CRFMICITES Working Group on Queen Conch, Panama City, Panama, 30 October - 1 November 2018. FAO Fisheries and Aquaculture Report No. 1263. Bridgetown. 96 pp.

FAO. 2020a. The State of World Fisheries and Aquaculture. 2020. Sustainability in Action. Rome.

Franckx, E. 2011. The relationship between CITES, FAO and related agreements: legal issues. FAO Fisheries and Aquaculture Circular. No. 1 062. Rome, FAO. 63p.

Gillet, R. 2010. Monitoring and management of the Humphead wrasse, Cheilinus undulatus. FAO Fisheries and Aquaculture Circular. No. 1 048. Rome, FAO. 62p.

Guggisberg, S. 2016. The Use of CITES for Commercially-exploited Fish Species: a solution to overexploitation and illegal, unreported and unregulated fishing? Springer International Publishing AG, The Hague.

Korwin, S., Dernier, L., Lieberman, S. \& Reeve, R. 2019. Verification of Legal Acquisition under the CITES Convention: the need for guidance on the scope of legality. Journal of International Wildlife Law and Policy, 22:3, 274-304.

Kuemlangan, B., Sanders, J., Deupmann, P. \& De Young, C. A. 2014. Integrative policy and legal instruments, approaches and tools: fisheries and biodiversity conservation. In: Garcia, S.M., Rice, J. \& Charles, A. (eds.) Governance of Marine Fisheries and Biodiversity Conservation: Interaction and Coevolution. Wiley-Blackwell. pp. 166-180.

Maguire, J.J., Sissenwine, M., Csirke, J., Grainger, R. \& Garcia, S. 2006. The state of the world migratory, straddling and other high seas fishery resources and associated species. FAO Fisheries Technical Paper. No. 495. Rome, FAO. 84 p. 
Molenaar, E.J. 2019. Participation in Regional Fisheries Management Organizations. In: Caddell, R. and Molenaar, E.J. (eds) Strengthening International Fisheries Law in an Era of Changing Oceans. Hart Publishing. pp. 103-129.

Monticini, P. 2014. Eel (Anguila spp.): production and trade according to Washington Convention Legislation. GLOBEFISH Research Programme. Vol. 114. Rome, FAO. 78p. at 60-61.

Mundy-Taylor, V. and Crook, V. 2013. Into the deep: Implementing CITES measures for commercially-valuable sharks and manta rays. Report prepared for the European Commission.

Mundy-Taylor, V., Crook, V., Foster, S., Fowler, S., Sant, G., \& Rice, J. 2014. CITES Non-detriment Findings Guidance for Shark Species (2nd, Revised Version). A Framework to assist Authorities in making Non-detriment Findings (NDFs) for species listed in CITES Appendix II. Report prepared for the Germany Federal Agency for Nature Conservation (Bundesamt für Naturschutz, BfN).

Ottolenghi, F. 2008. Capture-based aquaculture of bluefin tuna. In: Lovatelli, A. and Holthus, P.F. (Eds.) Capture-based aquaculture. Global overview. FAO Fisheries Technical Paper. No. 508 (2008). Rome, FAO. pp. 169-182.

Proelss, A. and Houghton, K. 2016. Protecting marine species, In: E. Morgera and K. Kulovesi (Eds.) Research Handbook on International Law and Natural Resources, Edward Elgar Publishing Limited, Cheltenham. Chapter 11, pp. 229-258.

Purcell, S.W., Samyn, Y. \& Connad, C. 2012. Commercially important sea cucumbers of the world. FAO Species Catalogue for Fishery Purposes. No. 6. Rome, FAO. 150 pp. 30 colour plates.

UNEP-WCMC. 2008. Monitoring of International Trade in Ornamental Fish. Consultation Paper prepared for the European Commission Directorate General E, Environment ENV.E.2., Development and Environment. 46p. at 18, 25.

Young, M. 2011. Trading Fish, Saving Fish: the interaction between regimes in international law. Cambridge University Press, Cambridge, UK.

Legally-binding international instruments

CITES. 1973. Convention on International Trade in Endangered Species of Wild Fauna and Flora (CITES). Adopted in Washington on 3 March 1973, entry into force on 1 July 1975, 993 UNTS 243.

CITES. 1979. Amendment to CITES. Adopted in Bonn on 22 June 1979, entry into force on 13 April 1987.

CITES. 1983. Amendment to CITES. Adopted in Gaborone on 30 April 1983, entry into force on 29 November 2013.

CITES. 1994a. Resolution Conf. 9.5(Rev.CoP16) Trade with States not party to the Convention. Adopted at CoP9, in Fort Lauderdale, United States of America, 7-18 November 1994. Amended at 13th, 14th and 15th meetings of CoP.

CITES. 1994b. Resolution Conf. 9.17, Status of International Trade in Shark Species. Adopted at CoP9, in Fort Lauderdale, United States of America, 7-18 November 1994 (but not longer valid). 
CITES. 1994c. Resolution Conf. 9.21 (Rev. CoP18) Interpretation and application of quotas for species included in Appendix I. Adopted at CoP9, in Fort Lauderdale, United States of America, 7-18 November 1994. Amended at 13th, 15th, 16th and 18th meetings of CoP.

CITES. 1994d. Resolution Conf. 9.24 (Rev. CoP17) Criteria for amendment of Appendices I and II. Adopted at CoP9, in Fort Lauderdale, United States of America, 7-18 November 1994. Amended at 12th, 13th, 14th and 15th meetings of CoP.

CITES. 1997. Resolution Conf.10.21 (Rev. CoP16) Transport of live specimens. Adopted at CoP10, in Harare, Zimbabwe, 9-20 June 1997. Amended at 14th and 16th meetings of CoP.

CITES. 2002a. Resolution Conf. 12.3 (Rev. CoP18) CITES permits and certificates. Adopted at CoP12, in Santiago, Chile, 3-15 November 2002. Amended at the 13th, 14th, 15th, 16th, 17th and 18th meetings of the CoP.

CITES. 2002b. Resolution Conf. 12.4 (Rev. CoP18) Cooperation between CITES and the Commission for the Conservation of Atlantic Marine Living Resources regarding trade in toothfish. Adopted at CoP12, in Santiago, Chile, 3-15 November 2002. Amended at the 18th meeting of the CoP.

CITES. 2002c. Resolution Conf. 12.6 (Rev. CoP17) Conservation and Management of Sharks. Adopted at CoP12, in Santiago, Chile, 3-15 November 2002. Amended at the 15th, 16th, 17th and 18th meetings of the CoP.

CITES. 2002d. Resolution Conf. 12.7 (Rev. CoP17) Conservation of and trade in sturgeons and paddlefish. Adopted at CoP12, in Santiago, Chile, 3-15 November 2002. Amended at the 13th, 14th, 16th and 17th meetings of the CoP.

CITES. 2004a. Resolution Conf. 13.2 (Rev. CoP14) Sustainable use of biodiversity: Addis Ababa Principles and Guidelines. Adopted at CoP13, in Bangkok, Thailand, 2-14 October 2004. Amended at the 14th meeting of the CoP.

CITES. 2004b. Resolution Conf. 13.3 Cooperation and synergy with the Convention on Migratory Species of Wild Animals (CMS). Adopted at CoP13, in Bangkok, Thailand, 2-14 October 2004.

CITES. 2007a. Resolution Conf. 14.6 (Rev. CoP16) Introduction from the Sea. Adopted at CoP14, in The Hague, Netherlands, 3-15 June 2007. Amended at the 15th meeting of the CoP.

CITES. 2007b. Resolution Conf. 14.7 (Rev. CoP15) Guidelines for the Management of nationally established export quotas. Adopted at CoP14, in The Hague, Netherlands, 3-15 June 2007.

CITES. 2013a. Resolution Conf. 16.7 (Rev. CoP17) Non-detriment findings. Adopted at CoP16, in Bangkok, Thailand, 3-14 March 2013. Amended at the 17th meeting of the CoP.

CITES. 2016a. Resolution Conf.17.8 Disposal of illegally traded and confiscated specimens of CITES-listed species. Adopted at CoP17, in Johannesburg, South Africa, 24 September4 October 2016.

CITES. 2019b. Resolution Conf. 18.3 CITES Strategic Vision: 2021-2030. Adopted at CoP18, in Geneva, Switzerland, 17-28 August 2019. 
CITES. 2019c. Resolution Conf.18.7 Legal acquisition findings. Adopted at CoP18, in Geneva, Switzerland, 17-28 August 2019.

CCAMLR. 2018. Conservation Measure 10-05 (2018) on Catch Documentation Scheme for Dissostichus spp. Adopted at Meeting CCAMLR-XXXVIII. (also available at https://www.ccamlr. org/en/measure-10-05-2018).

CMS. 1983. Convention on the Conservation of Migratory Species of Wild Animals (CMS). Adopted in Bonn on 23 June 1979, entry into force on force 1 November 1983, 1651 UNTS 355.

GFCM. 2019. Compendium of the General Fisheries Commission for the Mediterranean (GFCM) Decisions. July, 2019.

ICCAT. 2018. Compendium of management Recommendations and Resolutions adopted by ICCAT for the Conservation of Atlantic Tunas and Tuna-Like Species 2018.

ICRW. 1948. International Convention for the Regulation of Whaling (ICRW). Adopted in Washington D.C. on 2 December 1946, entry into force on 10 November 1948, 161 UNTS 72.

IOTC. 2019. Compendium of Active Conservation and Management Measures for the Indian Ocean Tuna Commission. Last updated on 29 October 2019. (also available at https://iotc.org/cmms).

LOSC. United Nations Convention on the Law of the Sea (LOSC). Adopted in Montego Bay on 10 December 1982, entry into force on 16 November 1994, 1883 UNTS 397.

NPFC. Active Conservation and Management Measures. In: Key documents [online]. [Cited 16 September 2020]. https://www.npfc.int/index.php/active-conservation-andmanagement-measures

PSMA. 2009. Agreement on Port State Measures Agreement to Prevent, Deter and Eliminate IIlegal, Unreported and Unregulated Fishing (PSMA). Adopted on 22 November 2009, entry into force on 5 June 2016, Rome.

SPRMO. 2019. Compilation of Conservation and Management Measures. (also available at https://www.sprfmo.int/assets/Fisheries/Conservation-and-Management-Measures/2019CMMs/All-2019-CMMs-compiled-reduced-size.pdf

UNFSA. 1995. Agreement for the Implementation of the Provisions of the United Nations Convention on the Law of the Sea of 10 December 1982 relating to the Conservation and Management of Straddling Fish Stocks and Highly Migratory Fish Stocks (UNFSA). Adopted in New York on 4 August 1995, entry into force on 11 December 2001, 2167 UNTS 3.

WCPFC. 2020. Conservation and Management Measures and Resolutions of the Western Central Pacific Fisheries Commission. Compiled 18 May 2020. [online]. [Cited 16 September 2020]. https://www.wcpfc.int/system/files/booklets/31/CMM\%20and\%20Resolutions.pdf 
Non-legally-binding international instruments

CITES. 2006. Memorandum of Understanding between the Food and Agriculture Organization of the United Nations (FAO) and the Secretariat of the Convention on International Trade in Endangered Species (CITES). Signed in 2006. (also available at https://cites.org/sites/default/ files/eng/disc/sec/FAO-CITES-e.pdf).

CITES. 2013b. Guidelines for the Non-Air Transport of Live Wild Animals and Plants. Adopted at CoP16, Bangkok, 2013.

FAO. 1995. Code of Conduct for Responsible Fisheries. Adopted in Rome, 31 October 1995.

FAO. 2001. International Plan of Action to prevent, deter and eliminate illegal, unreported and unregulated fishing. Rome. 24p.

UN. Declaration of the United Nations Conference on the Human Environment. Adopted in Stockholm on 16 June 1972, UN Doc. A/Conf.48/14, 11 ILM 1461.

UNGA. Resolution 70/1, Transforming our world: the 2030 Agenda for Sustainable Development. Adopted on 25 September 2015, UN Doc. A/RES/70/1, 21 October 2015.

\section{National legislation}

Tonga. Fisheries Management (Conservation) Regulations of 2008

United Republic of Tanzania. Fisheries Regulations G.N. No. 308 of 2009

Vanuatu. Fisheries Regulations Order of 2009

\section{Technical documents}

CITES. 2013c. Notification to the Parties No. $2013 / 012$ of 19 April 2013 concerning the Amendments to Appendices I and II of the Convention. Adopted at the Conference of the Parties at its 16th meeting, Bangkok (Thailand), 3-14 March 2013. (also available at https://www.cites. org/sites/default/files/eng/notif/2013/E-Notif-2013-012.pdf).

CITES. 2016b. Fact Sheet No. 7. Cooperation between ICCAT and CITES: capacity building in West Africa. (also available at https://cites.org/sites/default/files/eng/prog/shark/docs/Sharks_E_ fsht07_ICCAT.pdf).

CITES. 2016c. Fact Sheet No. 9. Cooperation between IOTC and CITES: improving capacity and data availability for CITES Parties in the Indian Ocean region. (also available at https://cites.org/sites/default/files/eng/prog/shark/docs/Sharks_E_fsht09_IOTC.pdf).

CITES. 2016d. Fact Sheet No. 8. Cooperation between SEAFDEC and CITES: capacity building in Southeast Asia. (also available at https://cites.org/sites/default/files/eng/prog/shark/docs/ Sharks_E_fsht08_SEAFDEC.pdf).

CITES. 2018d. Directory of wildlife enforcement network (WEN) focal points. (also available at https://cites.org/sites/default/files/eng/prog/iccwc/Directory_wildlife_enforcement_networksRevAug2018.pdf). 
CITES. 2019d. Notification to the Parties No. 2019/052 of 03 October 2019 concerning the Amendments to the Appendices I and II to the Convention. Adopted at the Conference of the Parties at its 18th meeting (Geneva, 17-28 August 2019) [online]. [Cited 16 September 2020]. https://www.cites.org/sites/default/files/notif/E-Notif-2019-052-.pdf

IATTC. 2019. Compendium of Active Resolutions and Recommendations (in force, January 2019). (also available at http://www.iattc.org/PDFFiles/Resolutions/IATTC/Compendium-ofactive-resolutions-and-recommendations.pdf).

ICCAT. 2019. Information on the Joint tRFMO Bycatch Working Group Meeting (16-18 December 2019, Porto, Portugal). (also available at https://www.iccat.int/Documents/ Meetings/JRFMOs2019/GENERAL_INFO_ENG.pdf).

ICCWC. 2016a. ICCWC Indicator Framework for Combating Wildlife and Forest Crime: a selfassessment framework for national use. Revised July 2016. (also available at https://cites.org/ sites/default/files/eng/prog/iccwc/E-ICCWC-Ind-FW-Assessment_guidelines_and_template.pdf).

ICCWC. 2016b. Strategic Programme 2016-2020. Revised July 2016. (also available at https://cites.org/sites/default/files/eng/prog/iccwc/ICCWC_Strategic_Programme_2016-2020 _final.pdf).

ICCWC. 2018. Implementation of the ICCWC Wildlife and Forest Crime Analytic Toolkit-summary of progress. Prepared by CITES Secretariat and UNODC, updated as 10 September 2018 [online]. [Cited 16 September 2020]. https://cites.org/sites/default/files/eng/prog/iccwc/lCCWC\%20 Toolkit\%20implementation\%20table\%20rev\%2010Sept2018-web.pdf

IOTC. 2017. Final Summary Report of the Stock Status of Oceanic Whitetip Sharks and CITES-Listed Hammerhead Sharks based on the Results of the IOTCICITES Sharks Data Mining Workshop. (also available at https://www.iotc.org/documents/final-summary-report-stock-status-oceanicwhitetip-sharks-and-cites-listed-hammerhead).

RECOFI. 2017. Report on the Implementation Status of RECOFI Decisions and Recommendations. RECOFI/IX/2017/6/E. [Cited 16 September 2020]. http://www.fao.org/fi/static-media/ MeetingDocuments/RECOFI/RECOFI_2017_9th/6e.pdf

UNODC. 2012. Wildlife and Forest Crime Analytic Toolkit. Revised Edition. UN, New York, USA. (also available at https://www.unodc.org/documents/Wildlife/Toolkit_e.pdf).

\section{Electronic sources}

BirdLife International. 2020. Data Zone, Species Search. In: Species [online]. [Cited 16 September 2020]. http://datazone.birdlife.org/species/search.

BMIS. n.d. Bycatch Management Information System. In: About [online]. [Cited 16 September]. https://www.bmis-bycatch.org/about-bmis

CBD. 2020. Liaison Group of Biodiversity-related Convention. In: Cooperation and partnerships [online]. [Cited 16 September 2020]. https://www.cbd.int/blg/ 
CITES. 2017b. FAO and world's leading fishery experts meet in Geneva to discuss CITES implementation for marine species, Press Release. [online]. [Cited 16 September 2020]. https:// cites.org/eng/news/pr/CITES_FAO_worlds_leading_fishery_experts_meet_in_Geneva_to_ discuss_CITES_implementation_for_marine_species_15032017

CITES. 2019e. CITES conference responds to extinction crisis by strengthening international trade regime for wildlife, Press Release. [online]. [Cited 16 September 2020]. https://cites.org/ eng/CITES_conference_responds_to_extinction_crisis_by_strengthening_international_trade_ regime_for_wildlife_28082019

CITES. n.d-a. Analysis of how CITES Strategic Vision objectives contribute to achieving the Aichi Biodiversity Targets established in the Strategic Plan for Biodiversity 2011-2020 (CBD COP decision X/2) [online]. [Cited 16 September 2020]. https://cites.org/sites/default/files/eng/com/ sc/66/Reporting/Revised $\% 20$ mapping $\% 20$ of $\% 20$ the $\% 20$ CITES $\% 20$ Strategic $\% 20$ Vision $\% 20$ against\%20Aichi.pdf

CITES. n.d-b. Appendices. In: Documents [online]. [Cited 16 September 2020]. https://cites.org/ eng/app/appendices.php

CITES. n.d-c. Brazil - National authorities. In: Country Profiles [online]. [Cited 16 September 2020]. https://www.cites.org/eng/parties/country-profiles/br/national-authorities

CITES. n.d-d. Conference of the Parties. In: Meetings [online]. [Cited 16 September 2020]. https://cites.org/eng/meetings/cop

CITES. n.d-e. Information resources from Parties and other stakeholders. In: Sharks and manta rays [online]. [Cited 16 September 2020]. https://cites.org/fra/prog/shark/resource_Parties_ stakeholders

CITES. n.d-f. Malaysia - National authorities. In: Country Profiles [online]. [Cited 16 September 2020]. https://cites.org/eng/parties/country-profiles/my/national-authorities

CITES. n.d-g. Model Law on International Trade in Wild Fauna and Flora (Model Law). CITES Secretariat. In: National legislation [online]. [Cited 16 September 2020]. https://cites.org/sites/ default/files/eng/prog/Legislation/E-Model\%20law-updated-clean.pdf

CITES. n.d-h. National CITES Authorities. In: Parties [online]. [Cited 16 September 2020]. https:// www.cites.org/eng/parties/country-profiles/national-authorities

CITES. n.d-i. Non-detriment findings. In: Implementation [online]. [Cited 16 September 2020]. https://www.cites.org/eng/prog/ndf/index.php

CITES. n.d-j. Projects and Activities. In: Sharks and manta rays [online]. [Cited 16 September 2020]. https://cites.org/eng/prog/shark/projects.php

CITES. n.d-k. Sri-Lanka - National authorities. In: Country Profiles [online]. [Cited 16 September 2020]. https://www.cites.org/eng/parties/country-profiles/lk/national-authorities

CITES. n.d-I. Standing Committee. In: Documents [online]. [Cited 16 September 2020]. https:// cites.org/eng/disc/sc.php 
CITES. n.d-m. United States of America - National authorities. In: Country Profiles [online]. [Cited 16 September 2020]. https://cites.org/eng/parties/country-profiles/us/national-authorities

FAO. 2020b. Database of measures on conservation and management of sharks. In: International Plan of Action for Conservation and Management of Sharks [online]. Rome. Database version 1-2020 [Cited 16 September 2020]. http://www.fao.org/ipoa-sharks/database-ofmeasures/en/

FAO. n.d-a. FAO Activities in relation to CITES and commercially-exploited aquatic species. In: FAO Fisheries Division [online]. Rome. Updated 17 August 2016. [Cited 16 September 2020]. http://www.fao.org/fishery/cites-fisheries/en

FAO. n.d-b. FAO Expert Advisory Panel for the assessment of proposal to amend CITES appendices. In: FAO Fisheries Division [online]. Rome. Updated 7 August 2019. [Cited 16 September 2020]. http://www.fao.org/fishery/cites-fisheries/ExpertAdvisoryPanel/en.

FAO. n.d-c. FIGIS - Fisheries Global Information System. In: FAO Fisheries Division [online]. Rome. [Cited 16 September 2020]. http://www.fao.org/fishery/figis/en

FAO. n.d-d. FishFinder. In: FAO Fisheries Division [online]. Rome. Updated 12 January 2017. [Cited 16 September 2020]. http://www.fao.org/fishery/fishfinder/about/en

FAO. n.d-e. GLOBEFISH - Analysis and information on world fish trade. [Cited 16 September 2020]. http://www.fao.org/in-action/globefish/background/who-we-are/en/

FAO. n.d-f. iSharkFin. In: International Plan of Action for Conservation and Management of Sharks [online]. Rome. [Cited 16 September 2020]. http://www.fao.org/ipoa-sharks/tools/ software/isharkfin/en/

FAO. n.d-g. Parties to the PSMA. In: Agreement on Port State Measures (PSMA) [online]. Rome. [Cited 16 September 2020]. http://www.fao.org/port-state-measures/background/ parties-psma/en/

IATA. n.d. IATA's Live Animal Regulations. In: Cargo COVID-19 [online]. [Cited 16 September 2020]. https://www.iata.org/whatwedo/cargo/live-animals/Pages/index.aspx

IUCN. n.d-a. Background \& History. In: About [online]. [Cited 16 September 2020]. https://www. iucnredlist.org/about/background-history

IUCN. n.d-b. Table 1b "Number of threatened species by major group of organisms". In: Resources [online]. [Cited 16 September 2020]. https://www.iucnredlist.org/resources/ summary-statistics\#Summary\%20Tables

IUCN. n.d-c. Table 2 "Changes in numbers of species in the threatened categories (CR, EN, VU) from 1996 to 2019 (IUCN Red List version 2019-1) for the major taxonomic groups on the Red List". In: Resources [online]. [Cited 16 September 2020]. https://www.iucnredlist.org/resources/ summary-statistics\#Summary\%20Tables

UN. 2017. CITES working for sustainable fisheries delivering on needs-driven capacity building, by the Convention on Internationa Trade in Endangered Species of Wild Fauna and Flora. 
In: The Ocean Conference [online]. [Cited 16 September 2020]. https://oceanconference.un.org/ commitments/?id=15374

UNEP-WCMC (Comps.). n.d. Checklist of CITES Species [online]. [Cited 16 September 2020]. http://checklist.cites.org/\#

WoRMs. 2020. Authoritative classification and catalogue of marine species [online]. [Cited 16 September 2020]. http://www.marinespecies.org/index.php 
STUDY
ANNEXES

STUDY
ANNEXES

更

S

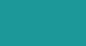




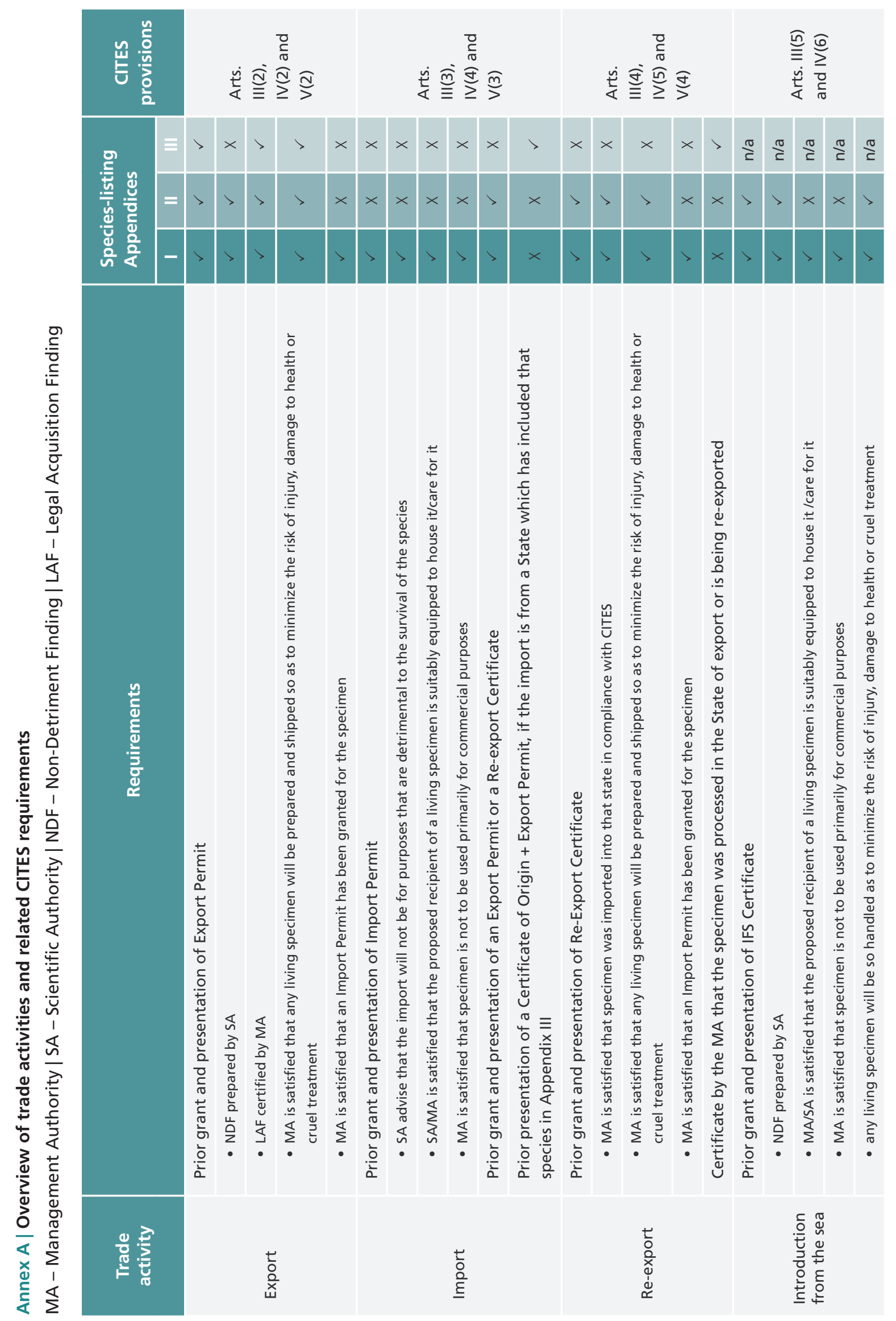




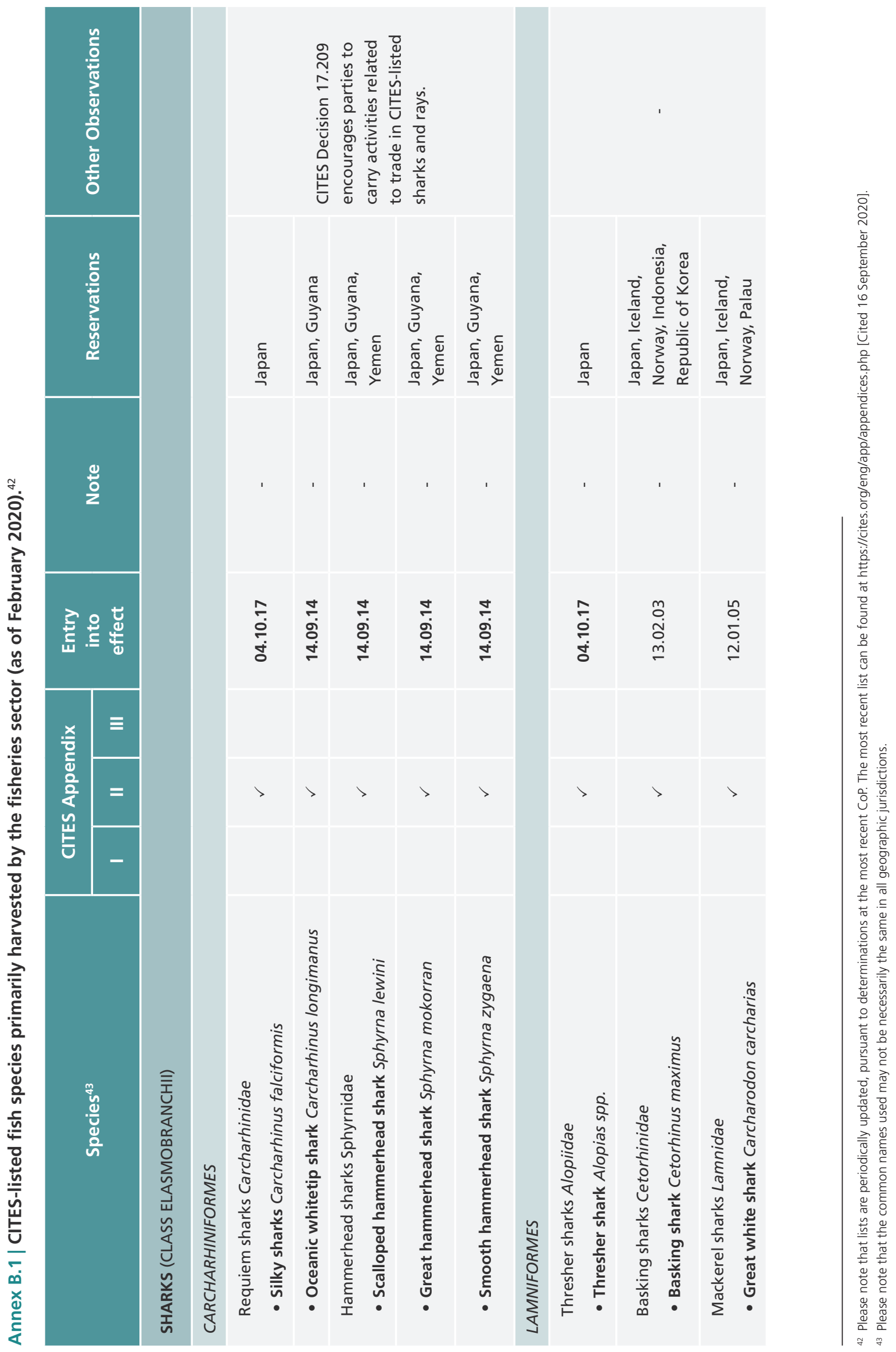




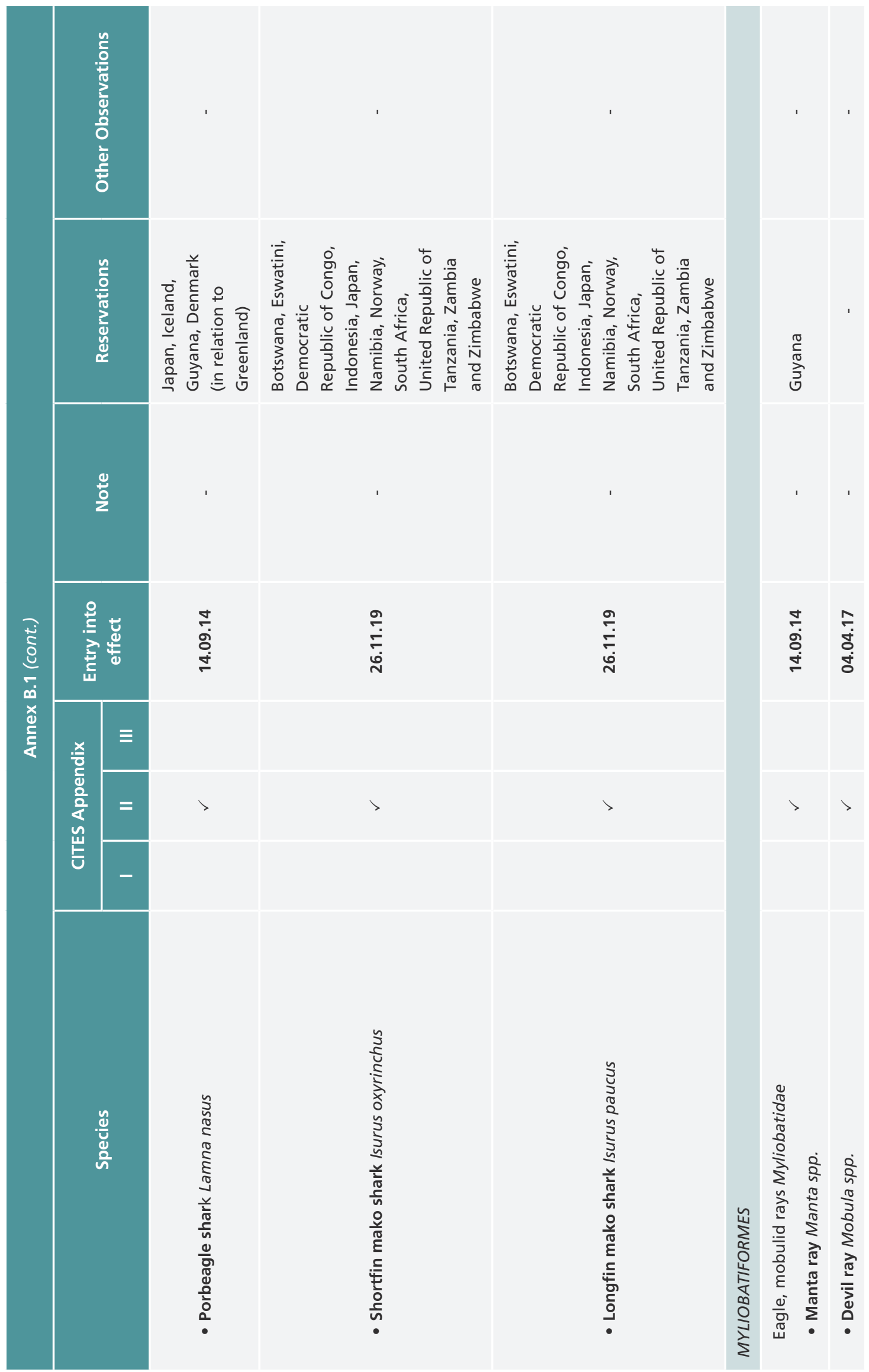




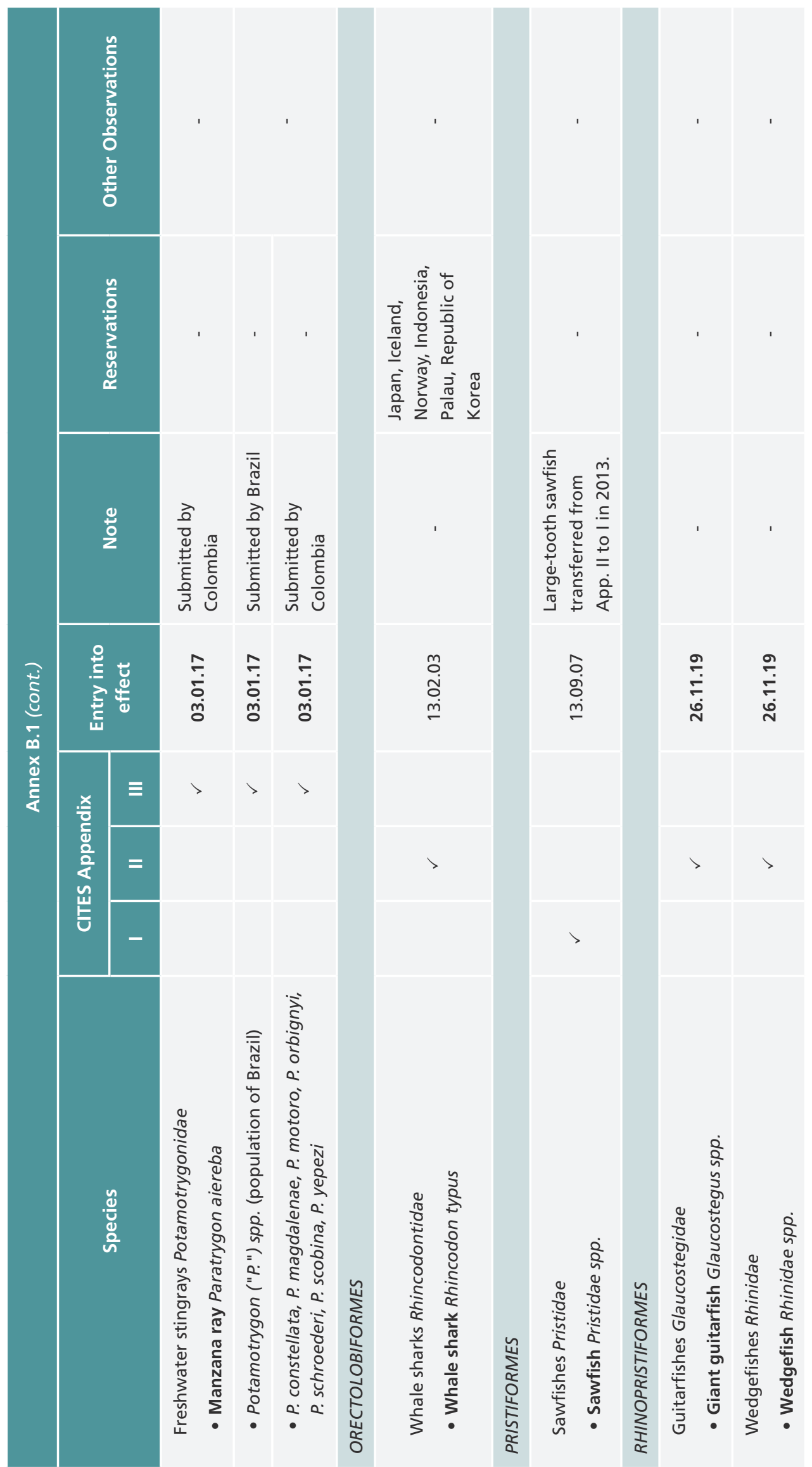




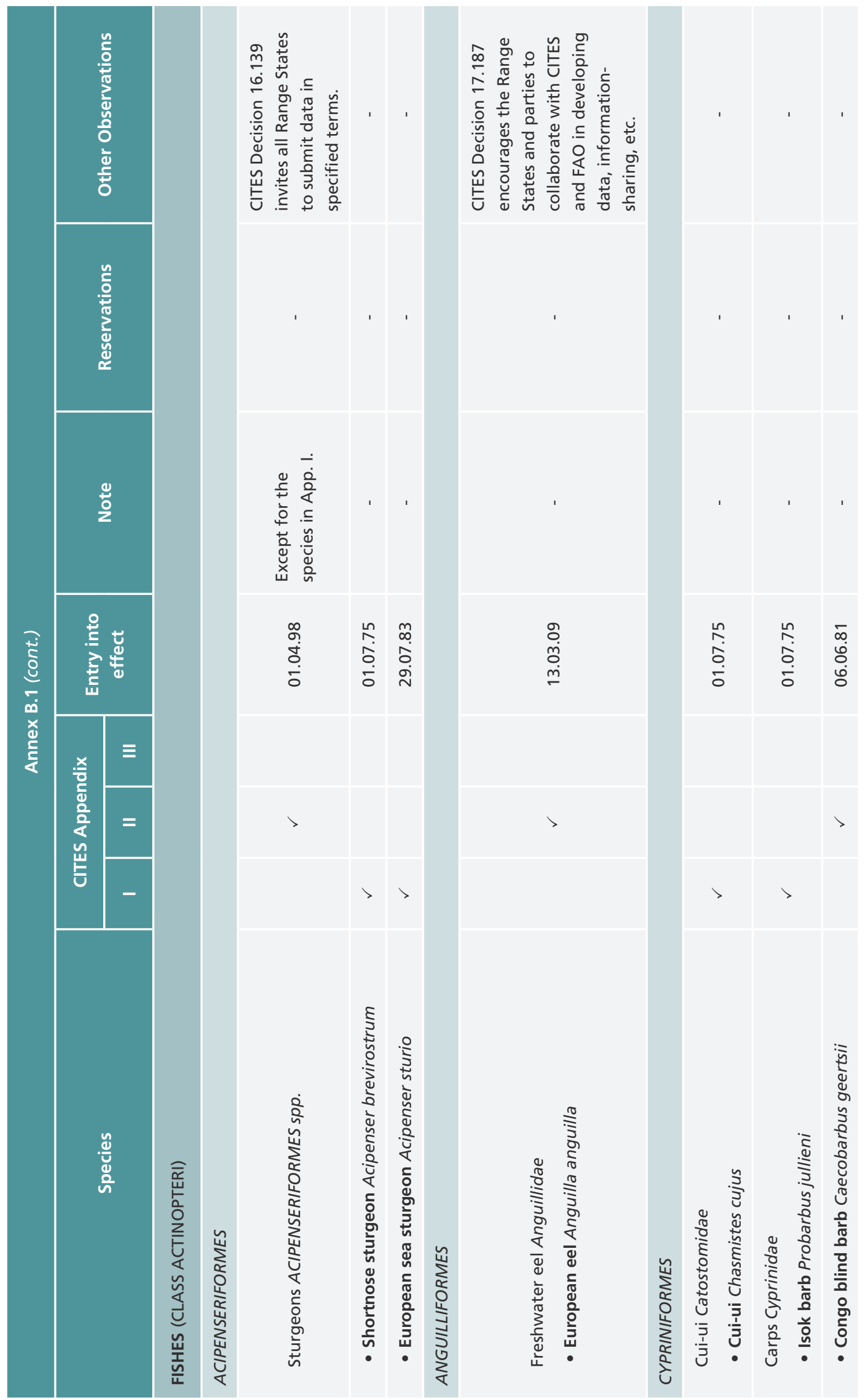




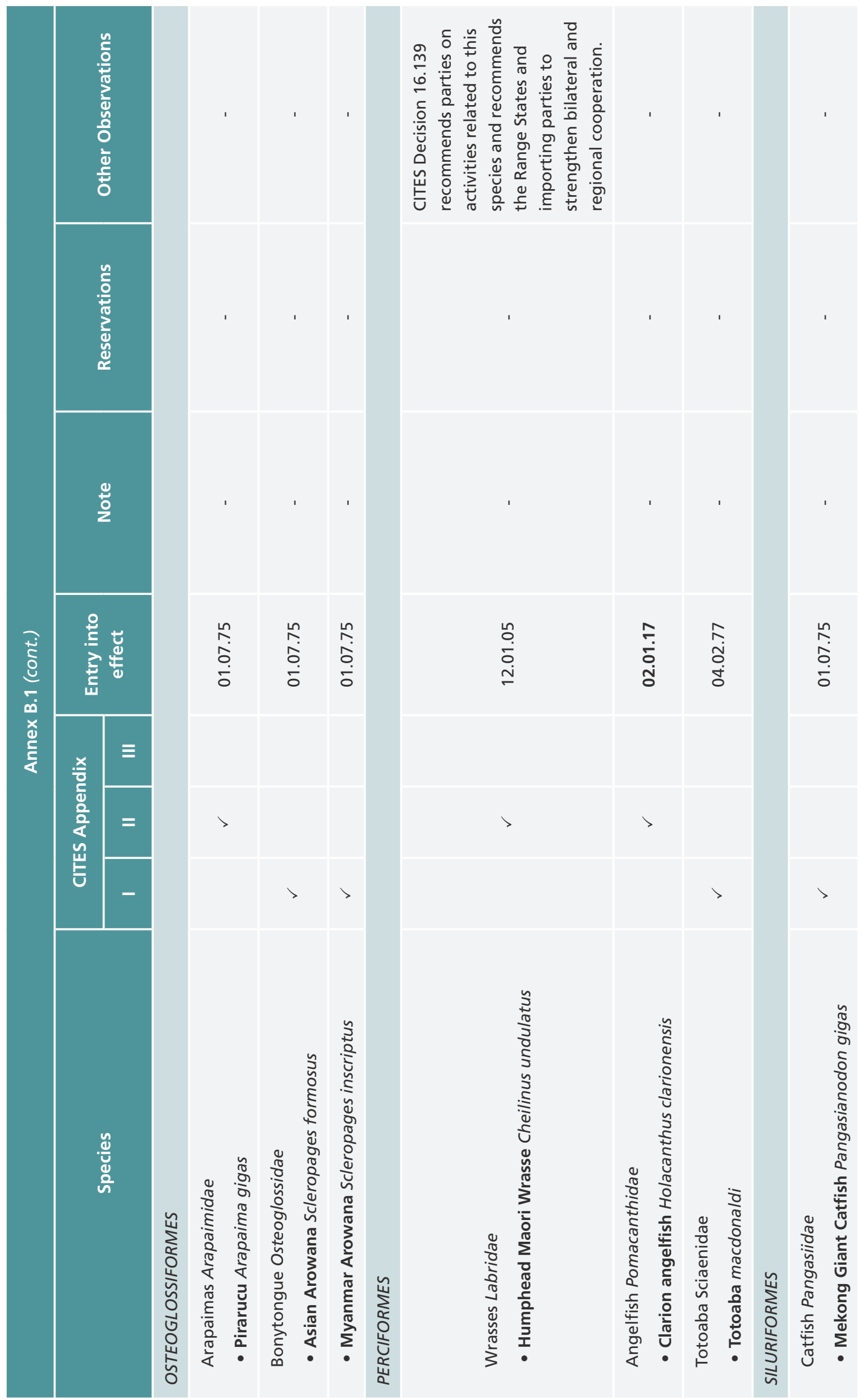




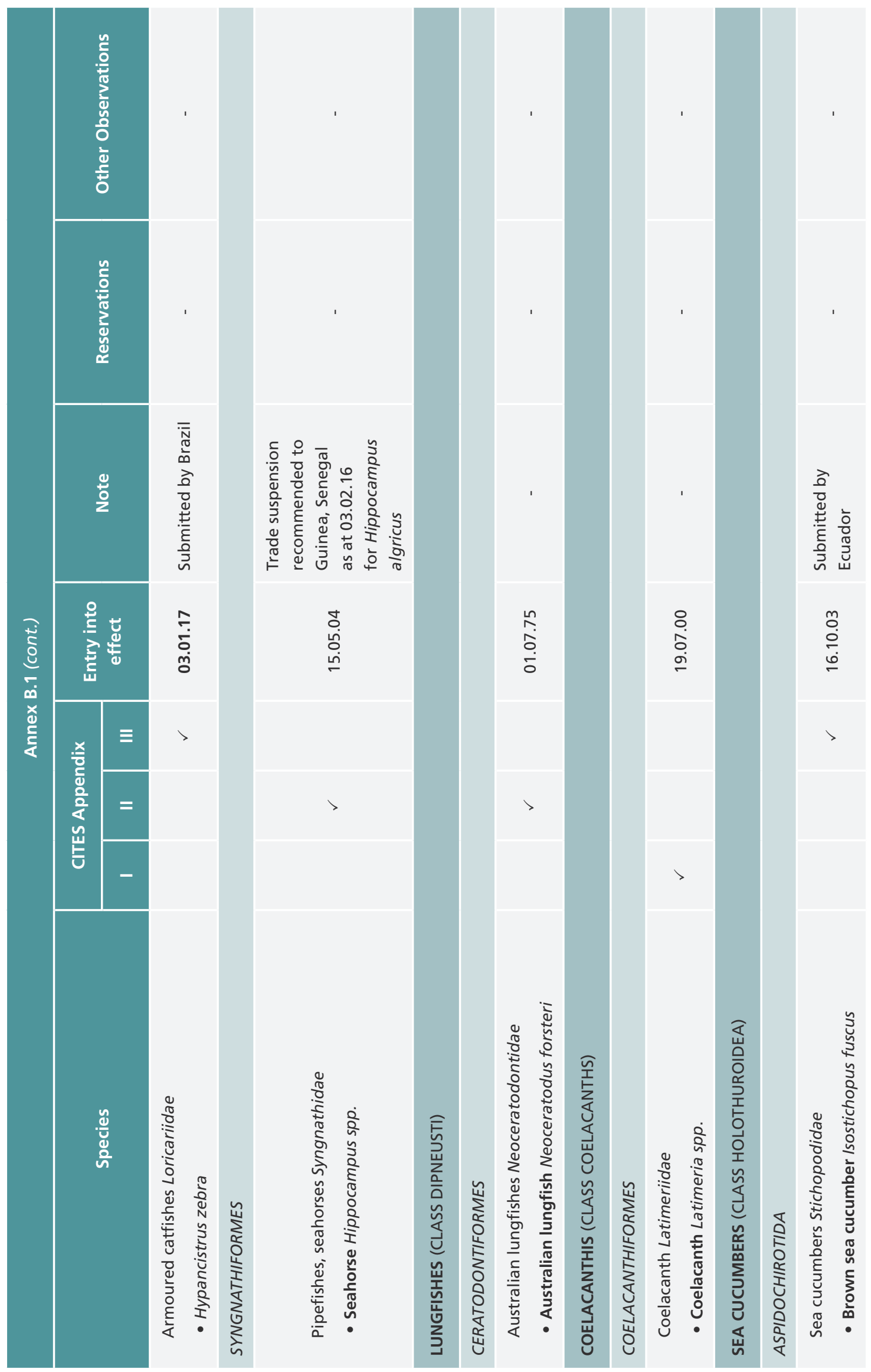




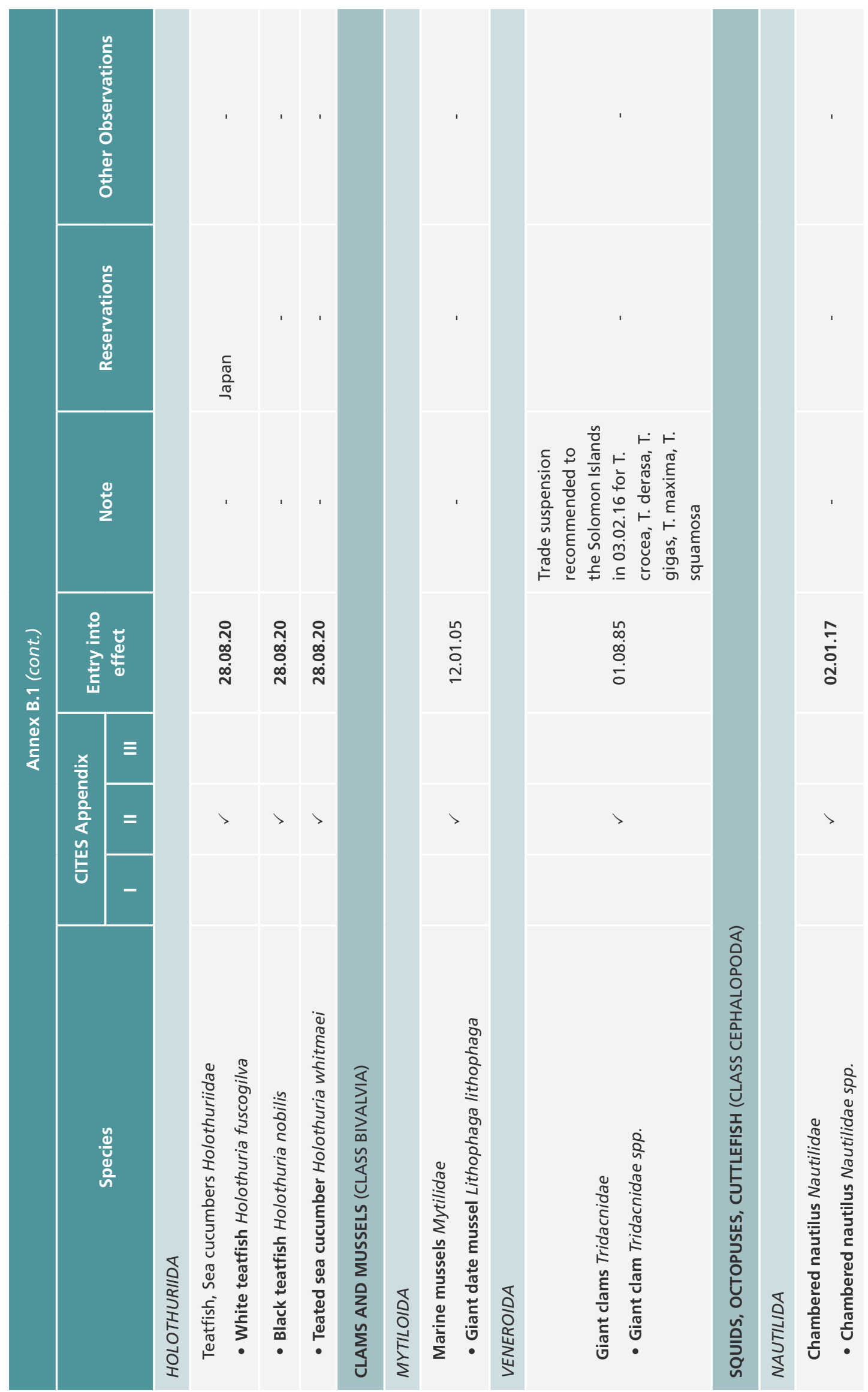




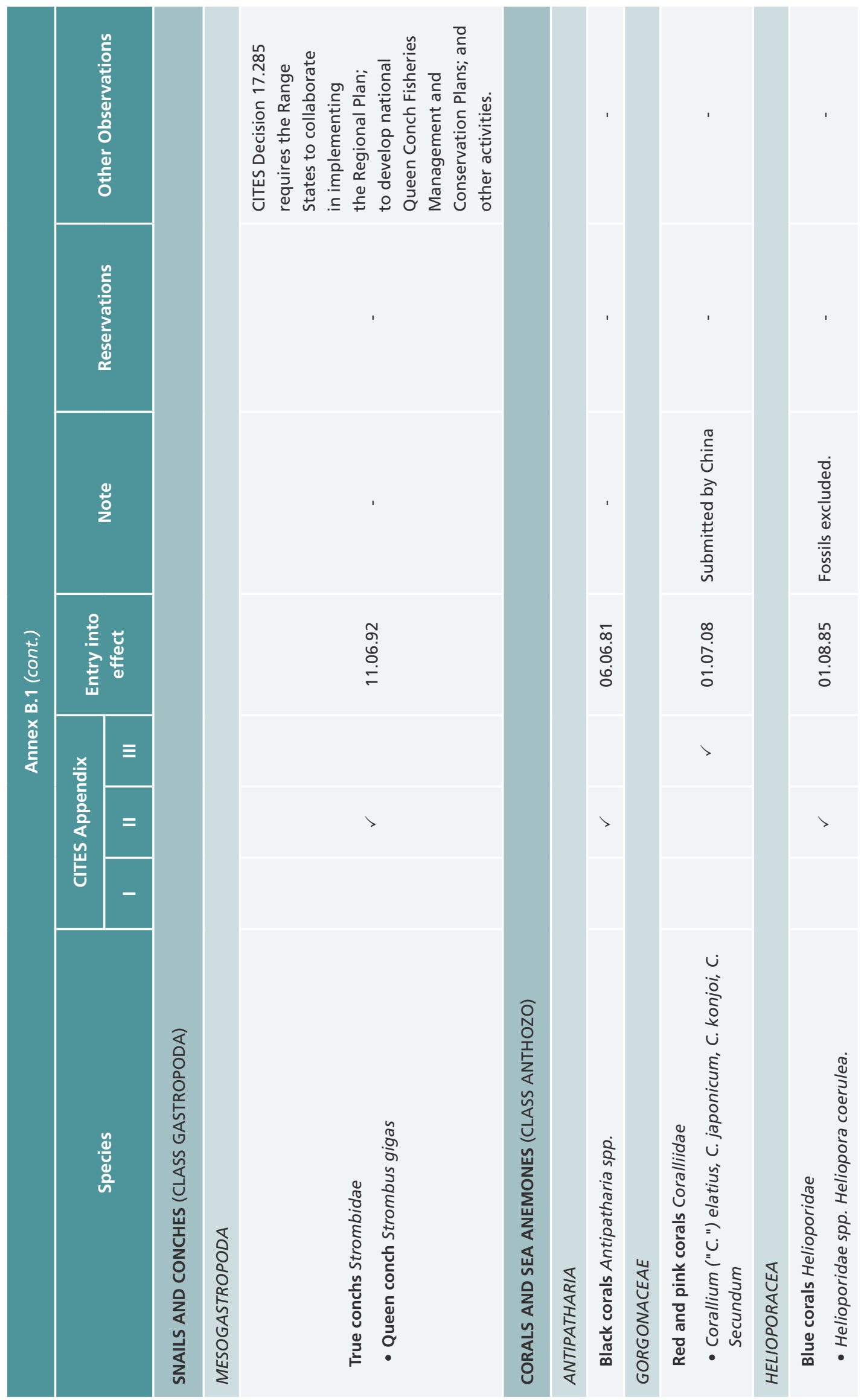




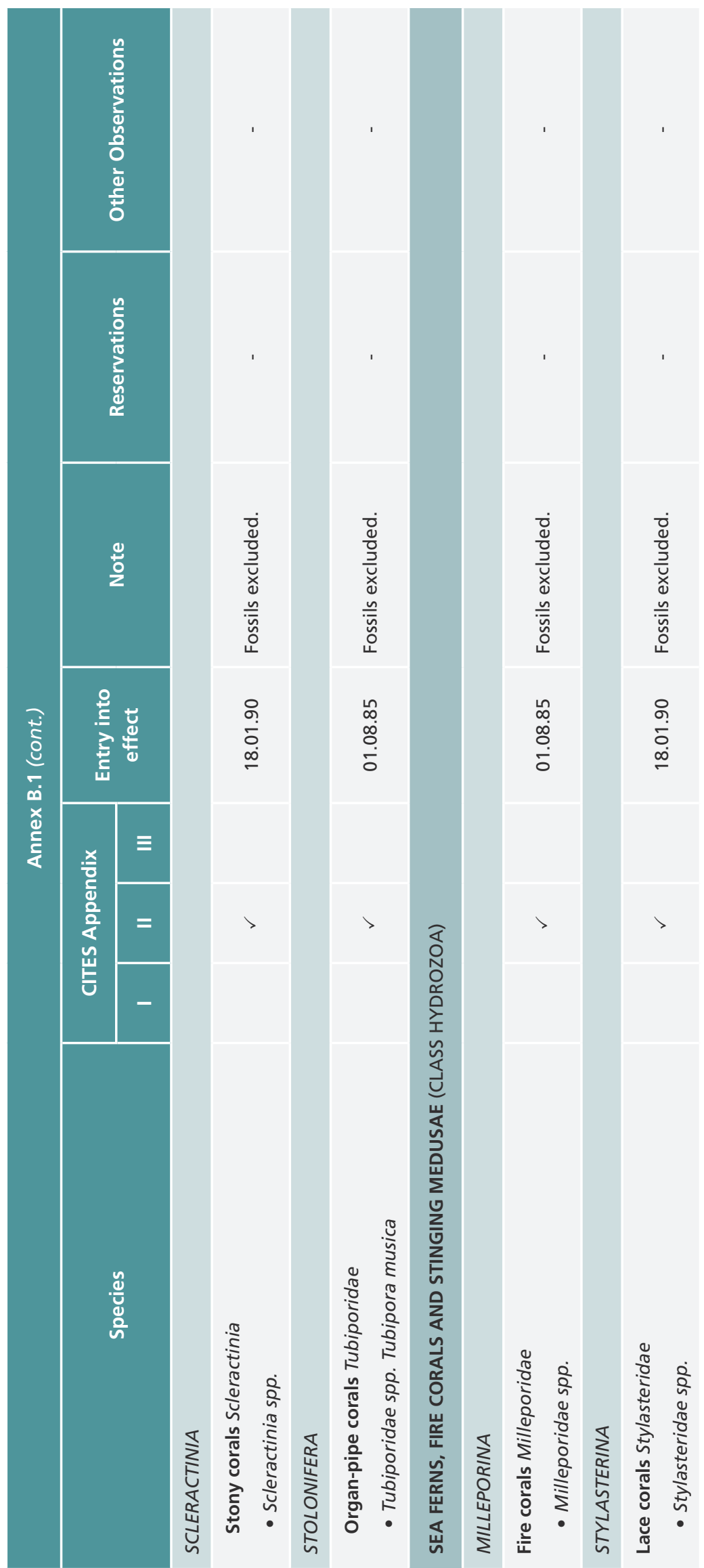




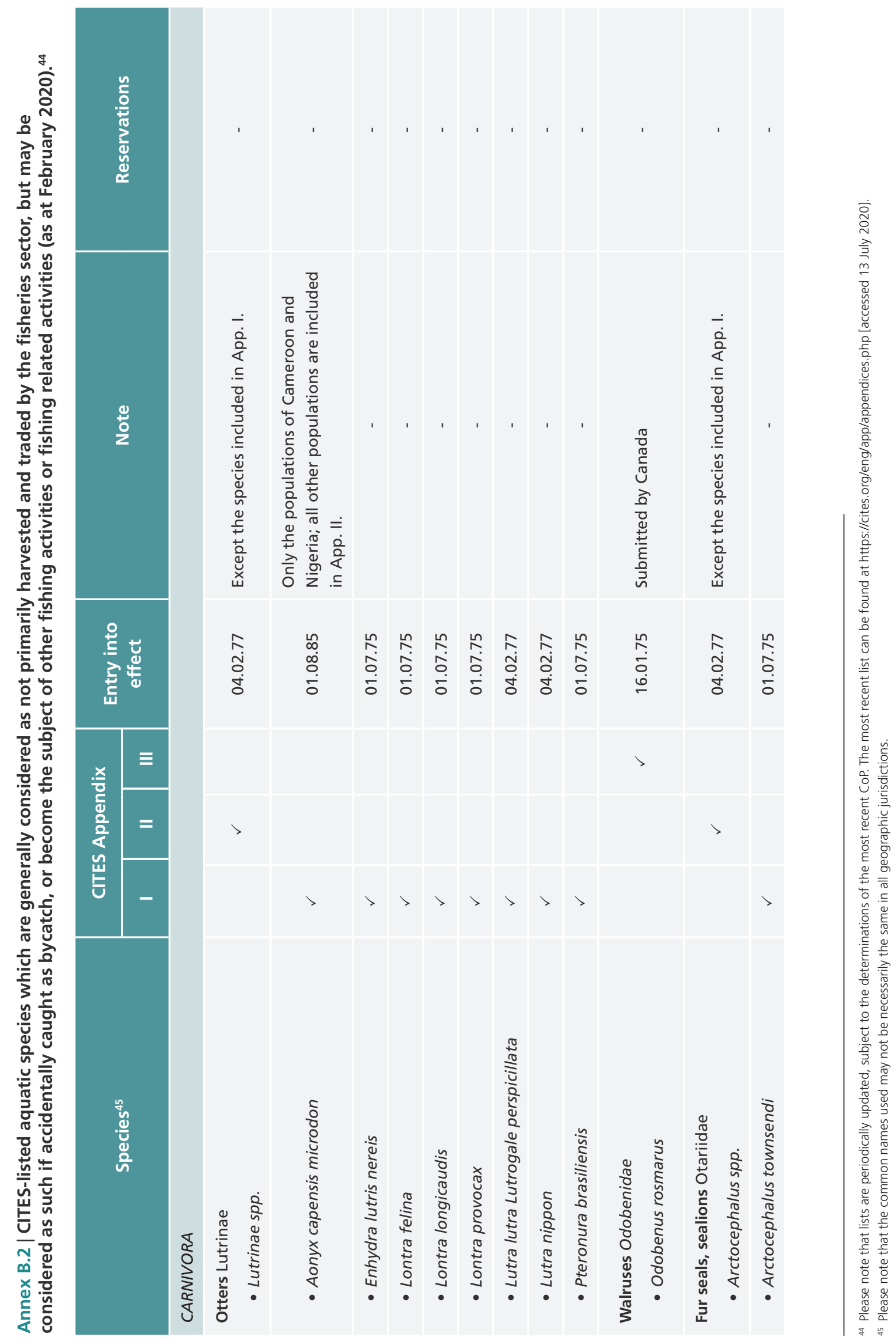




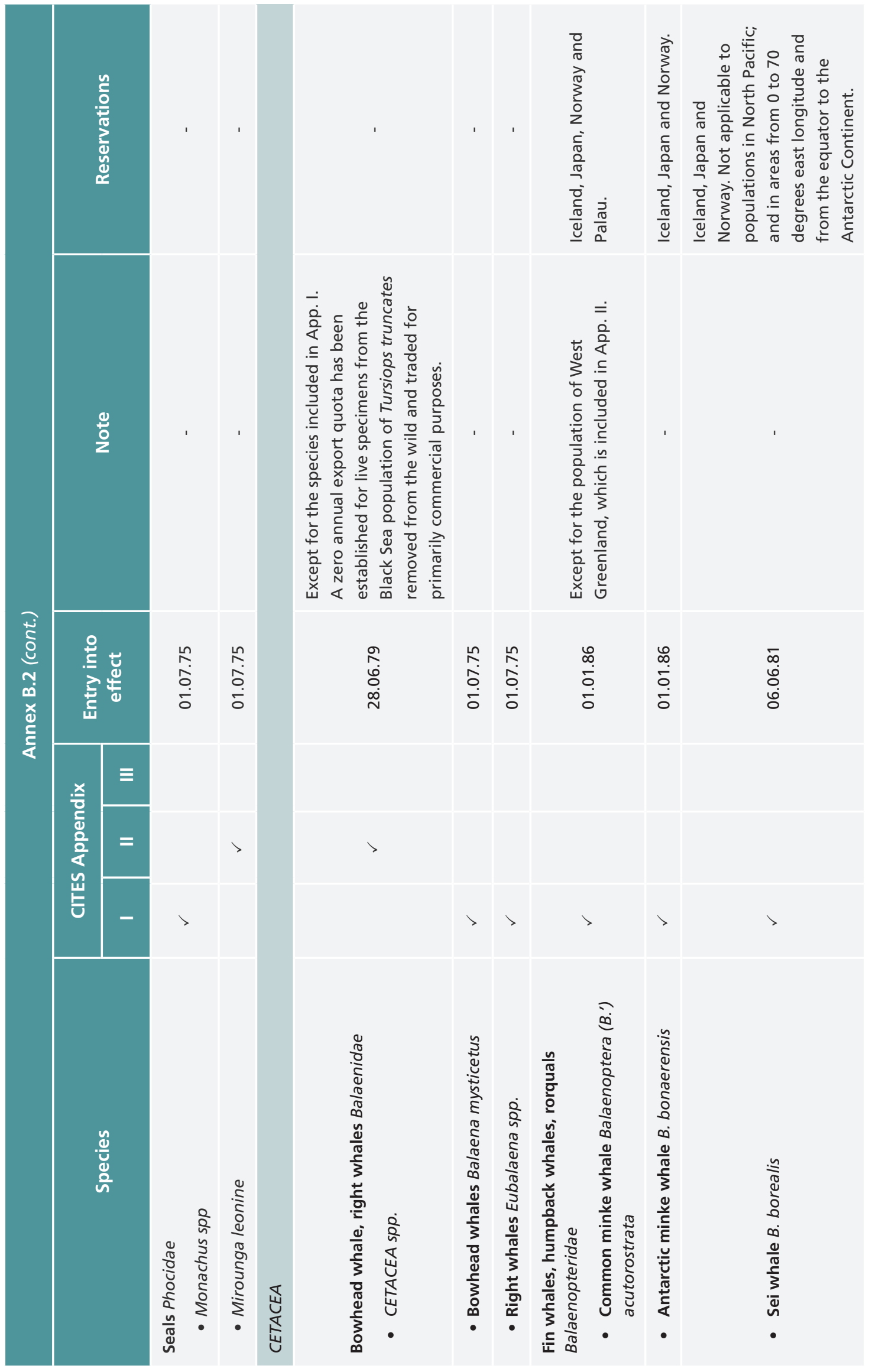




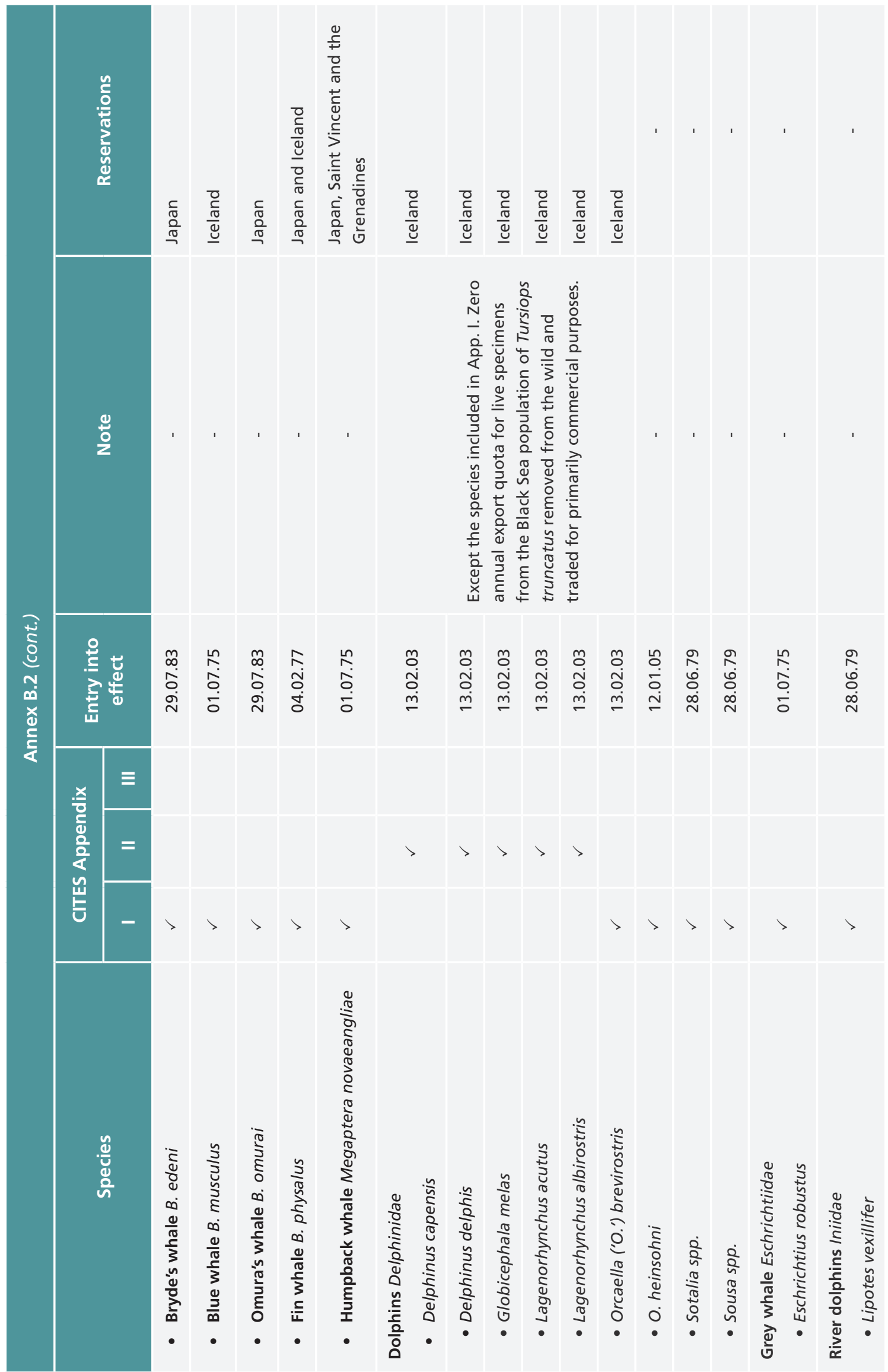




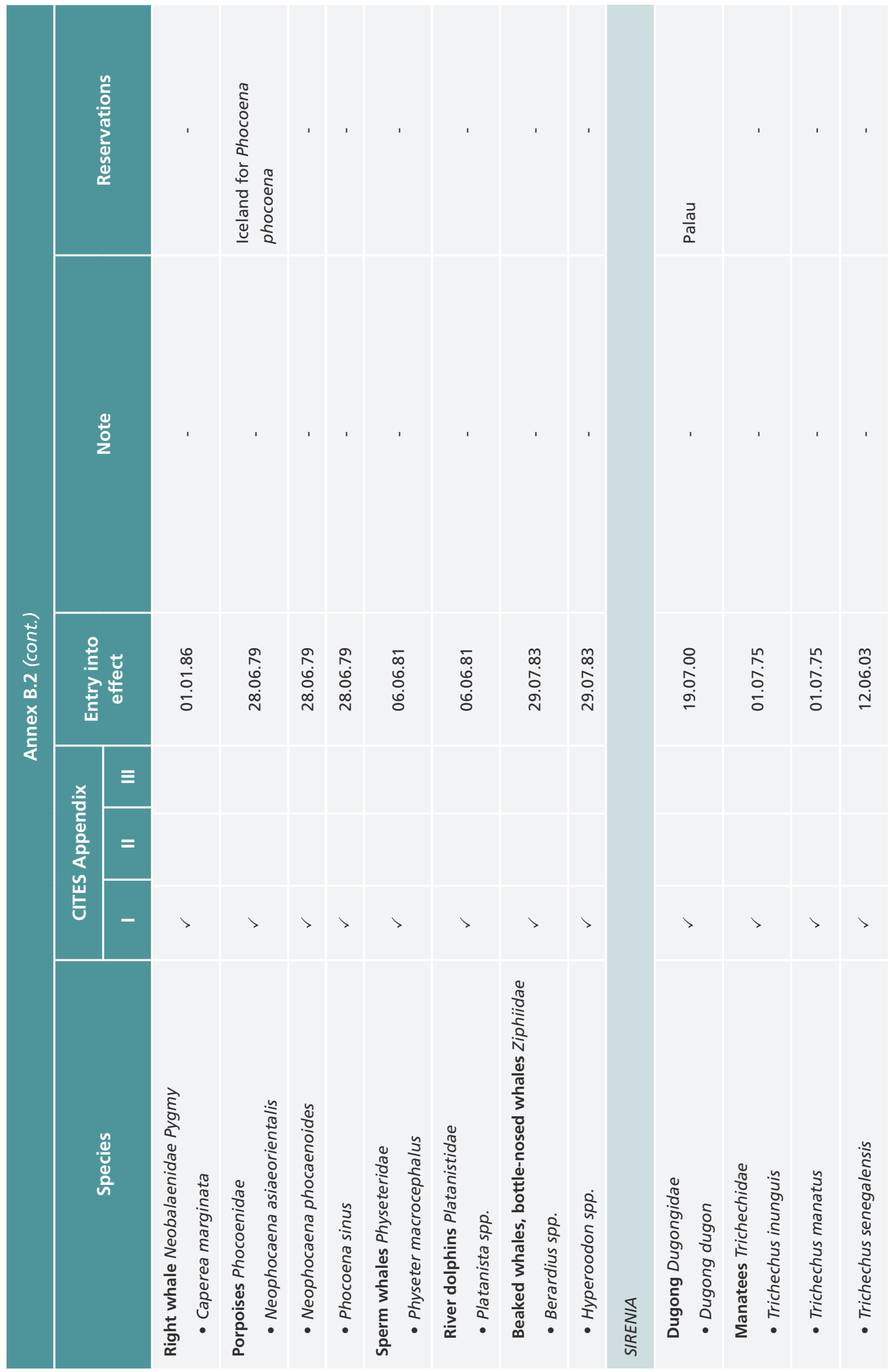




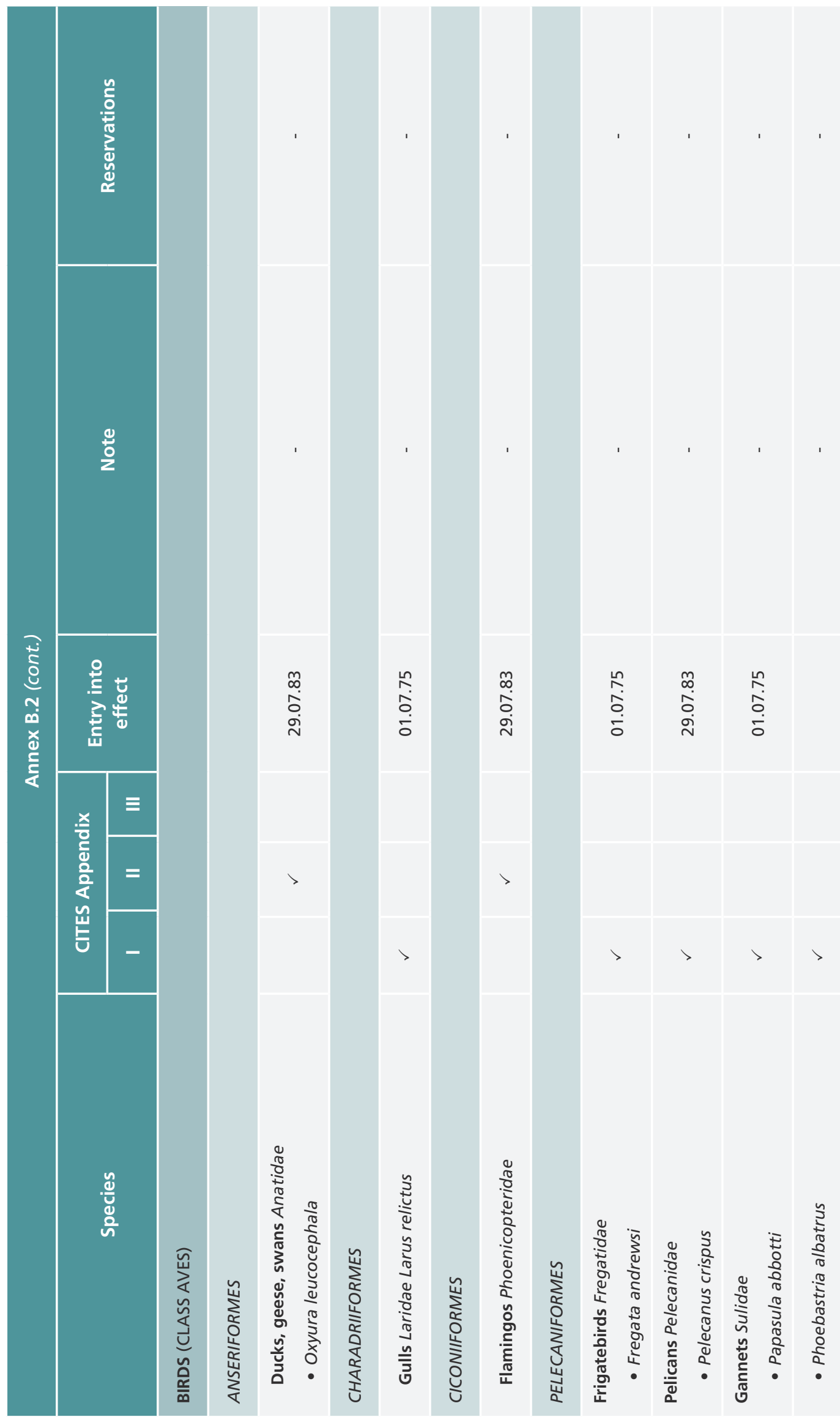




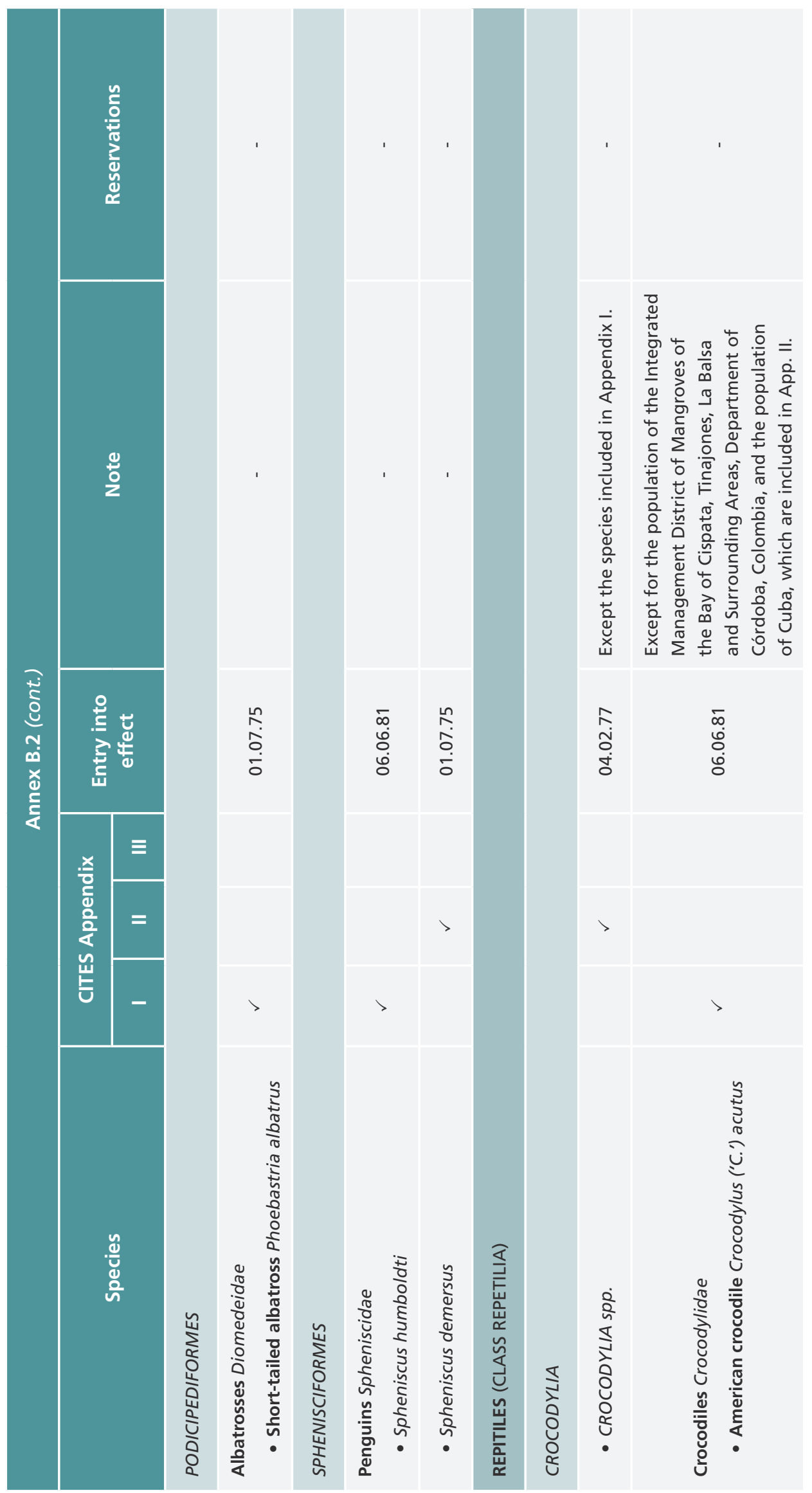




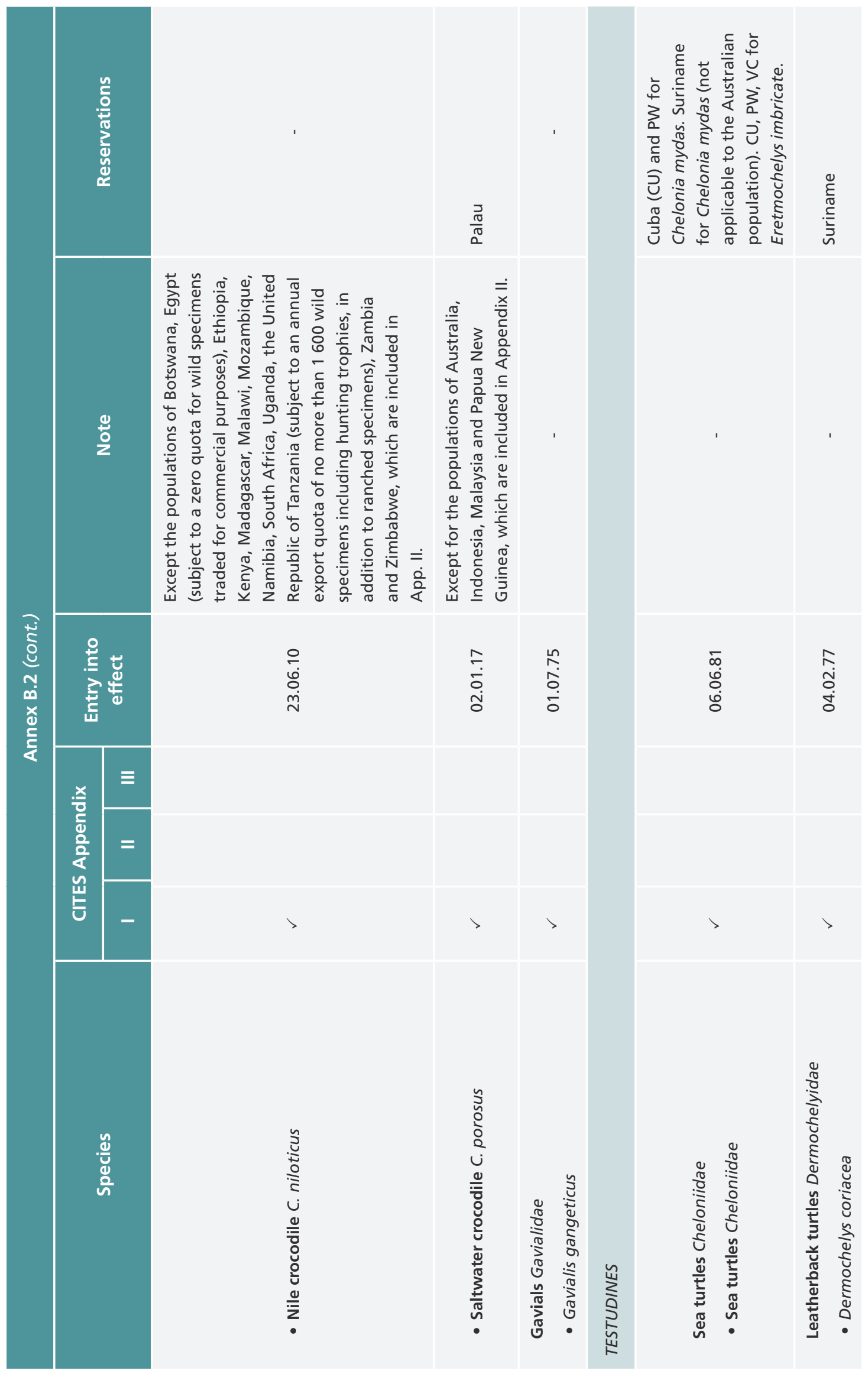




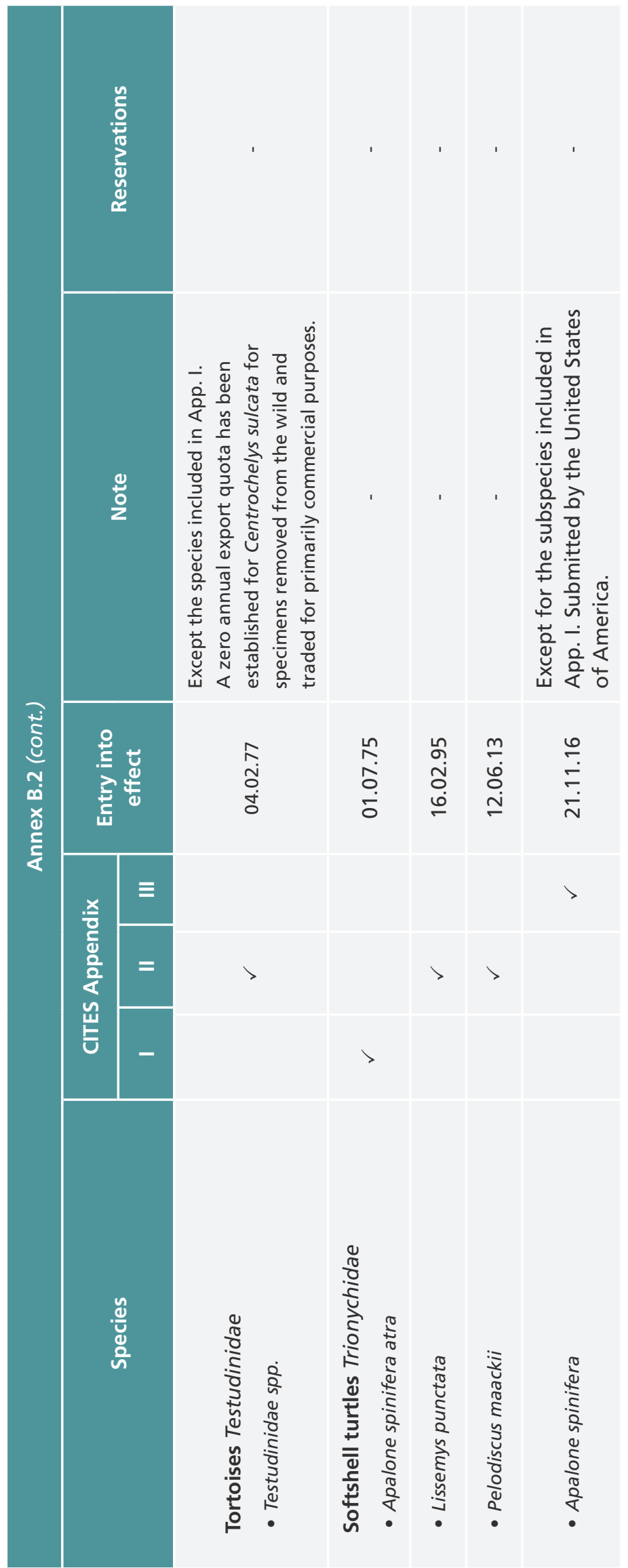



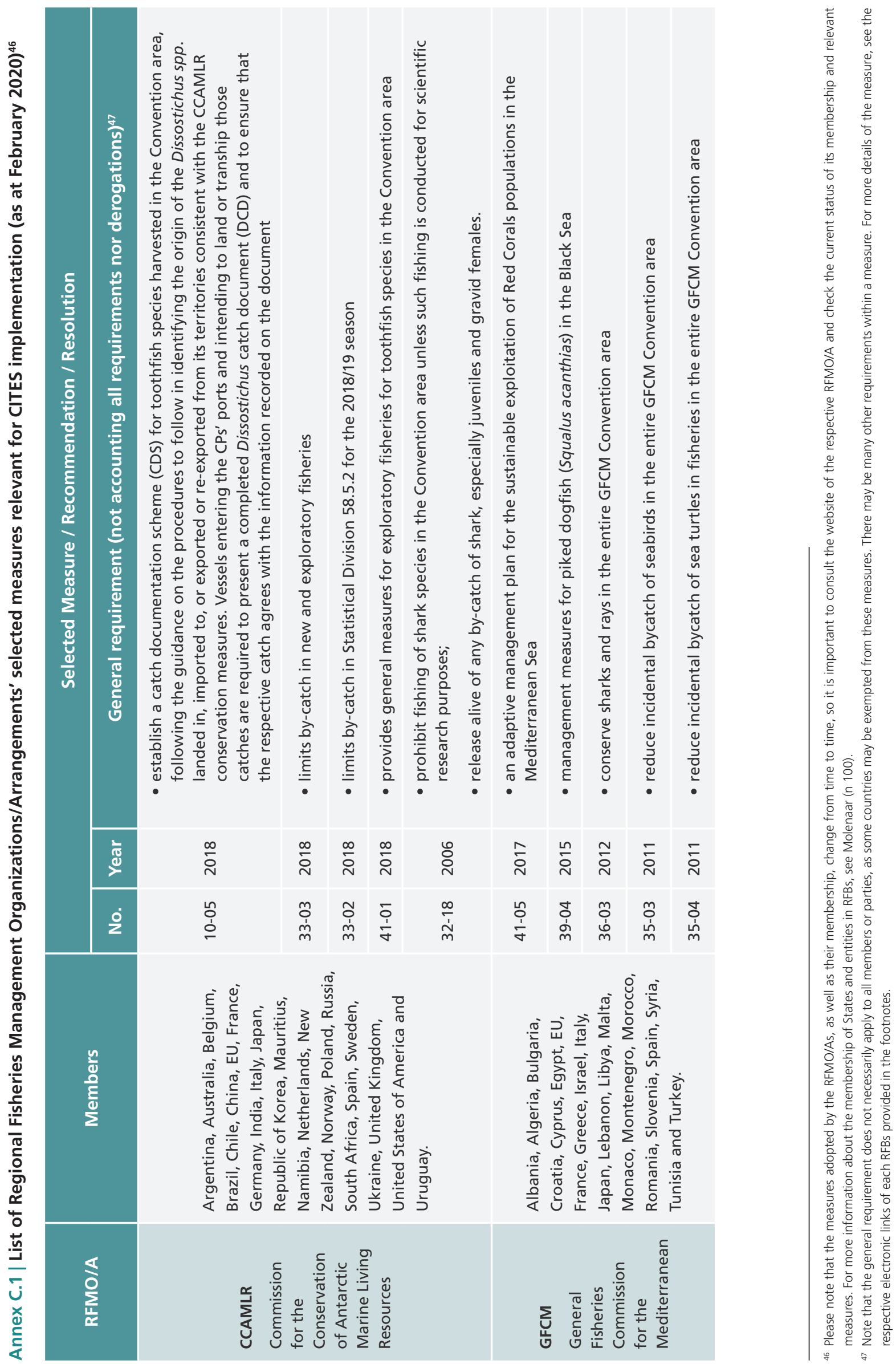


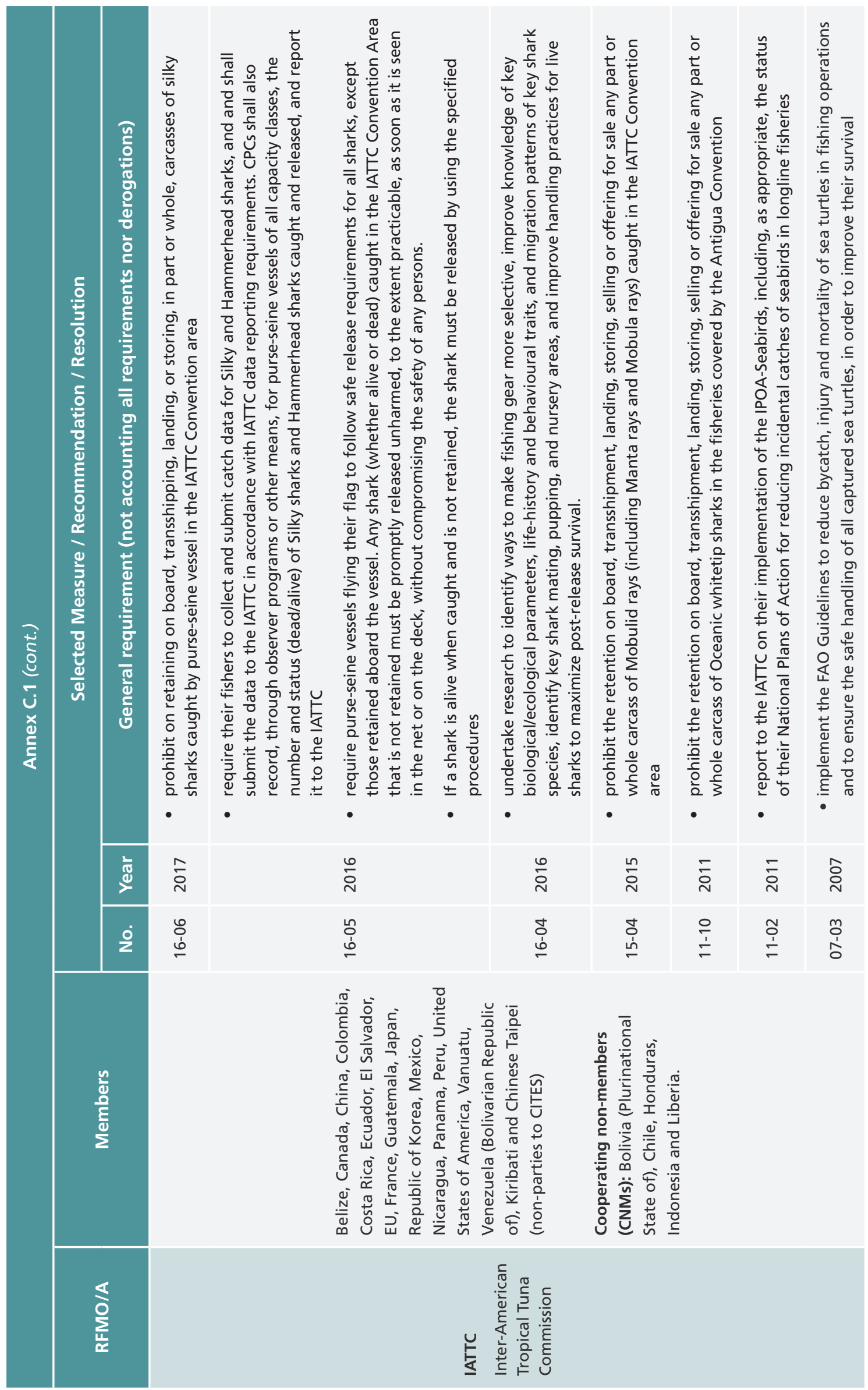




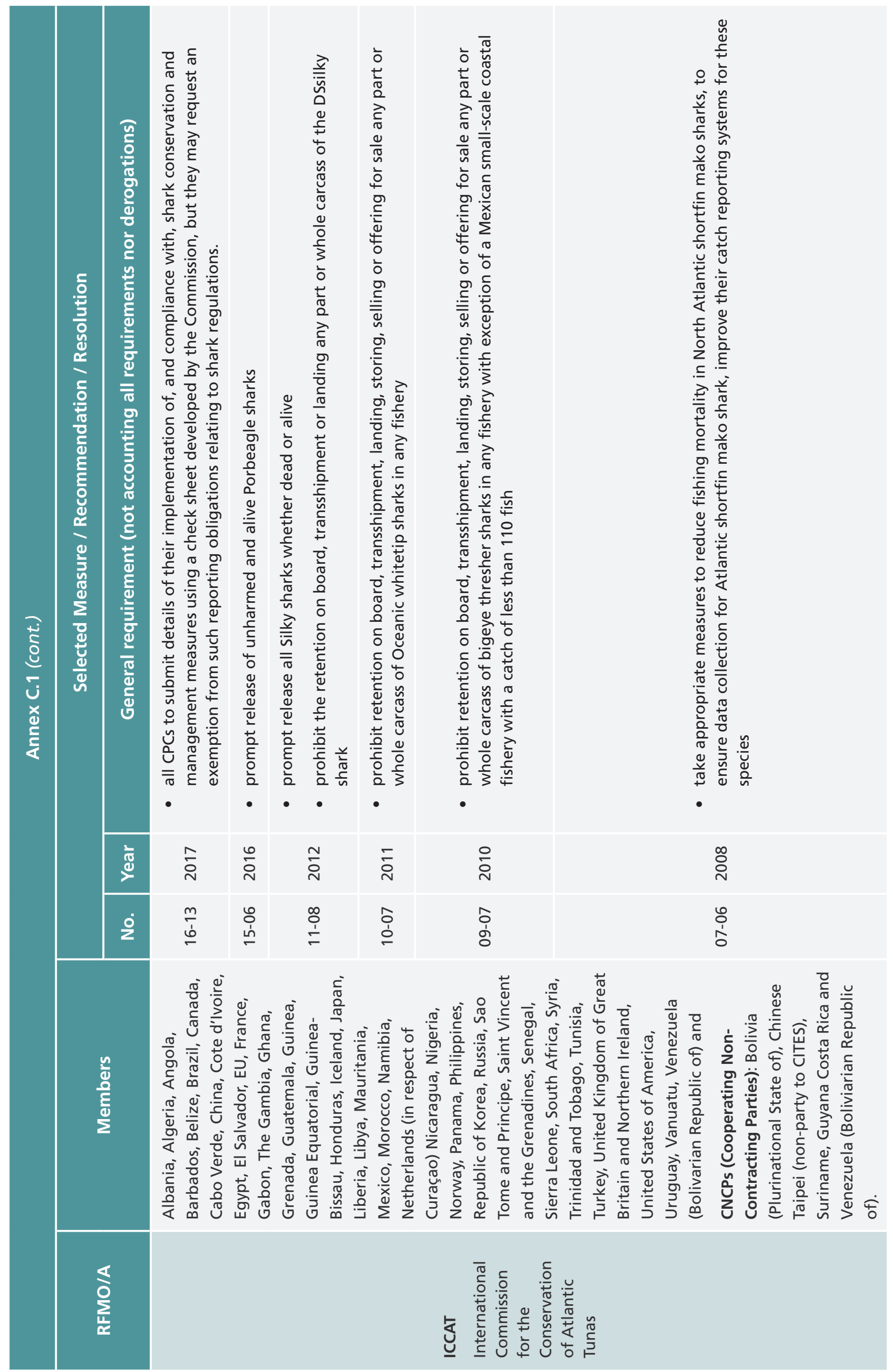




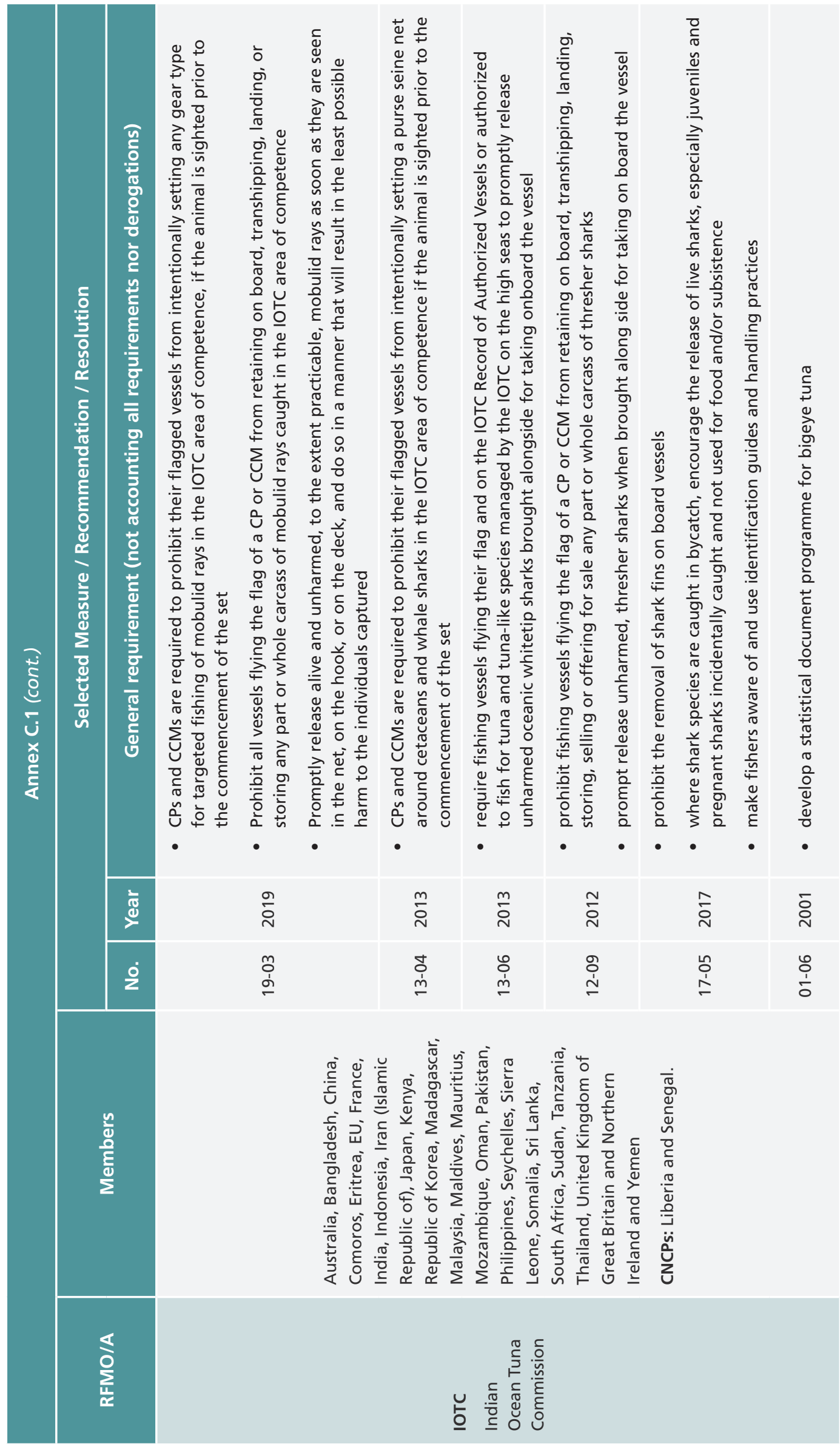




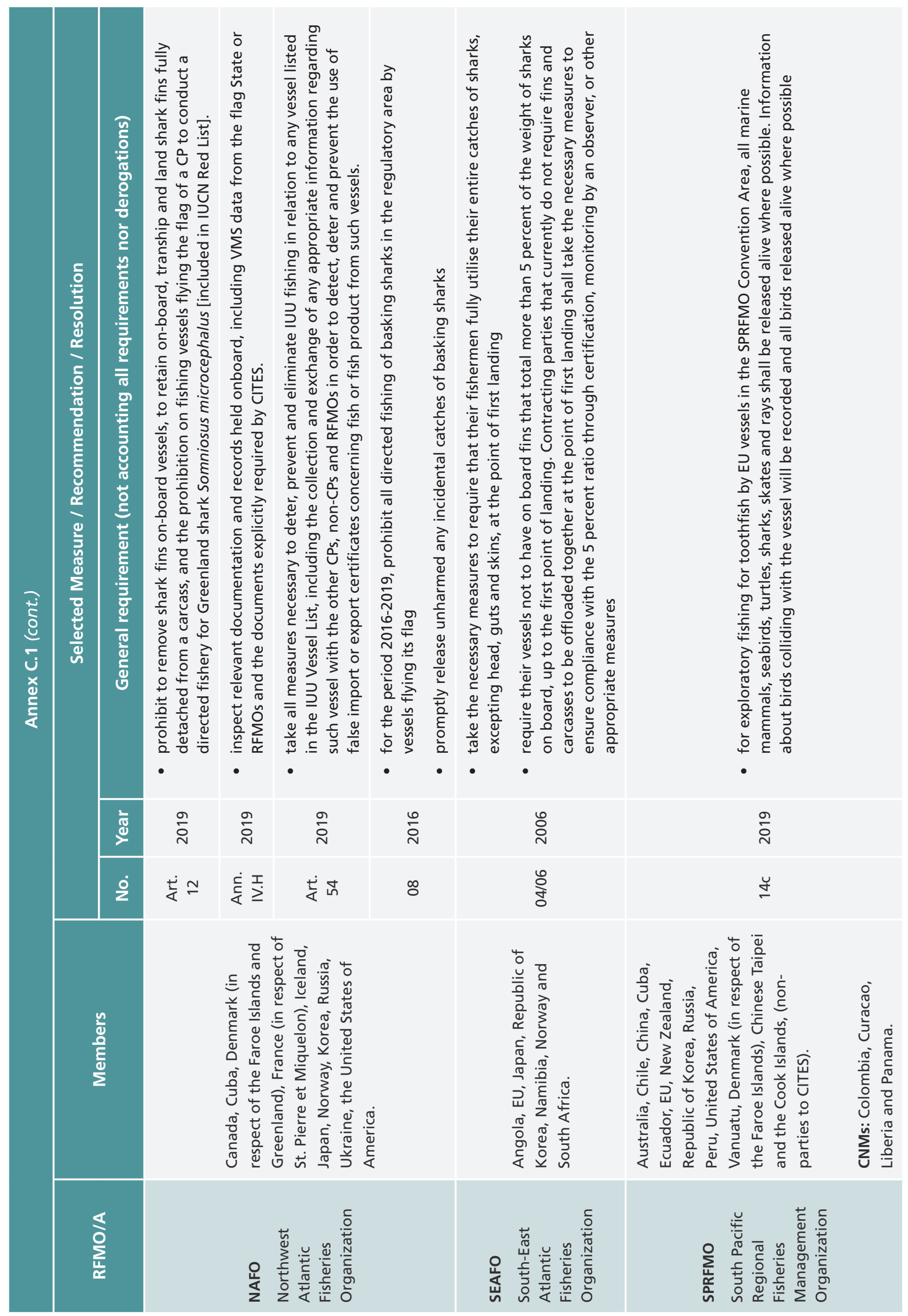




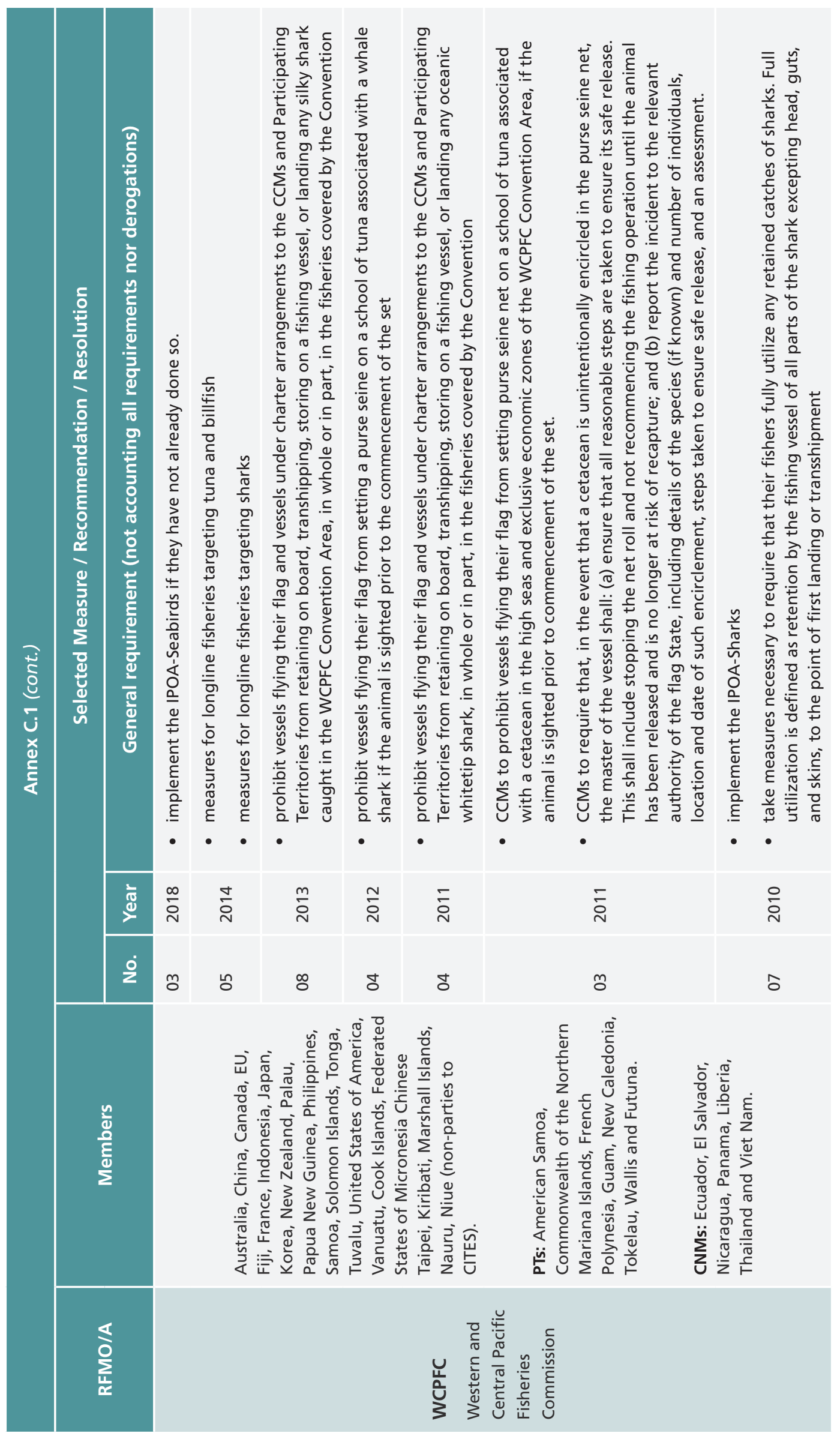




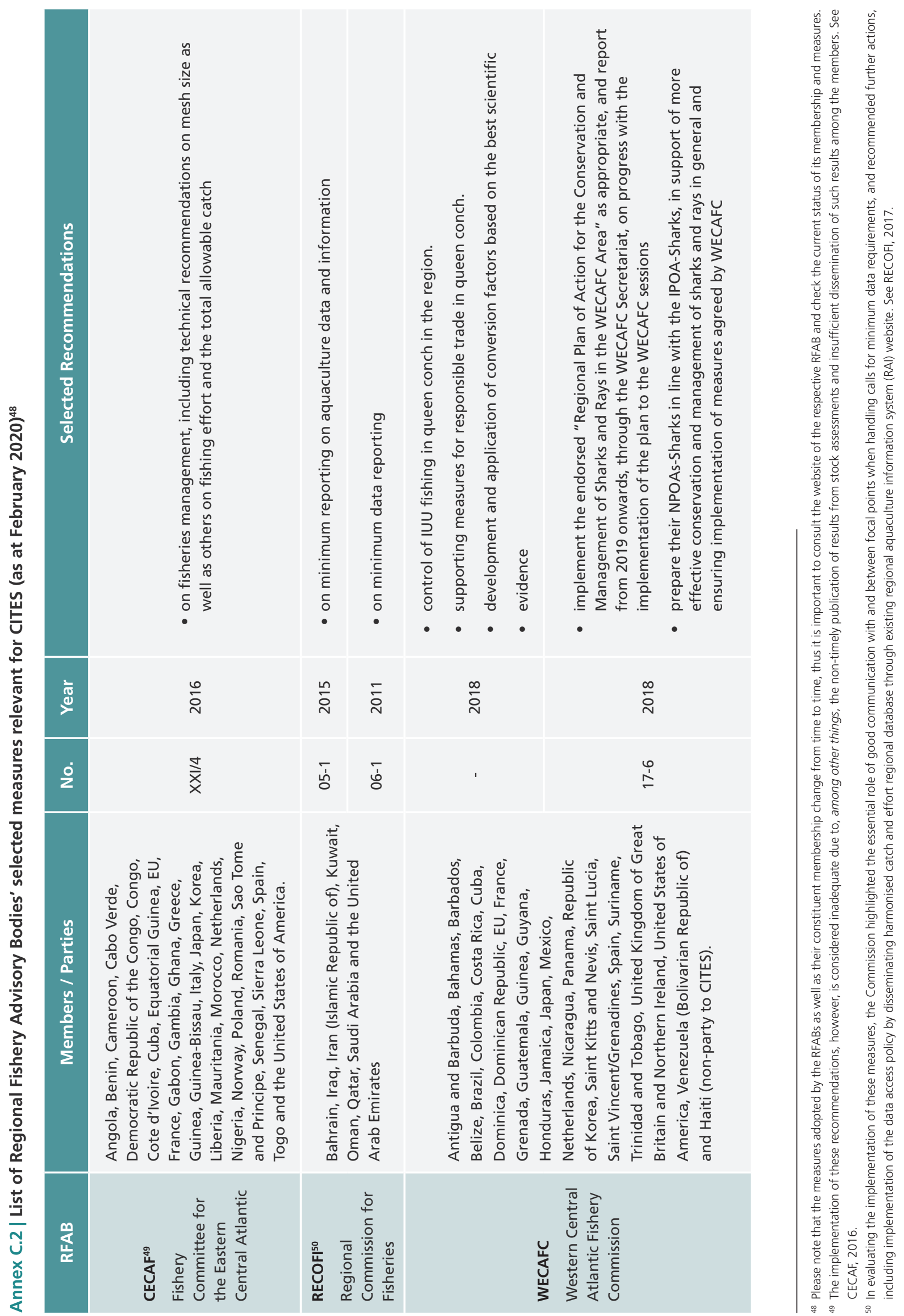




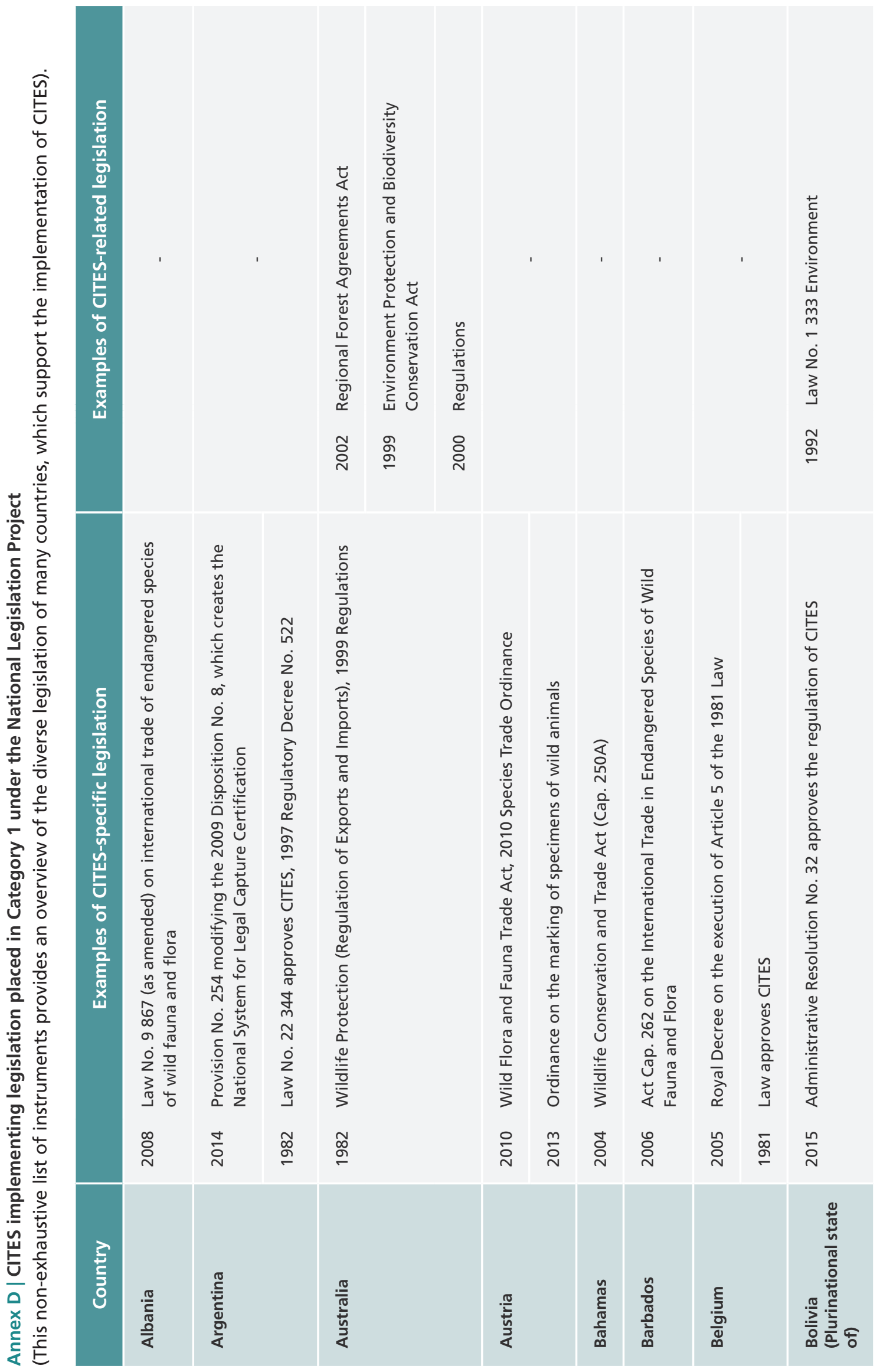




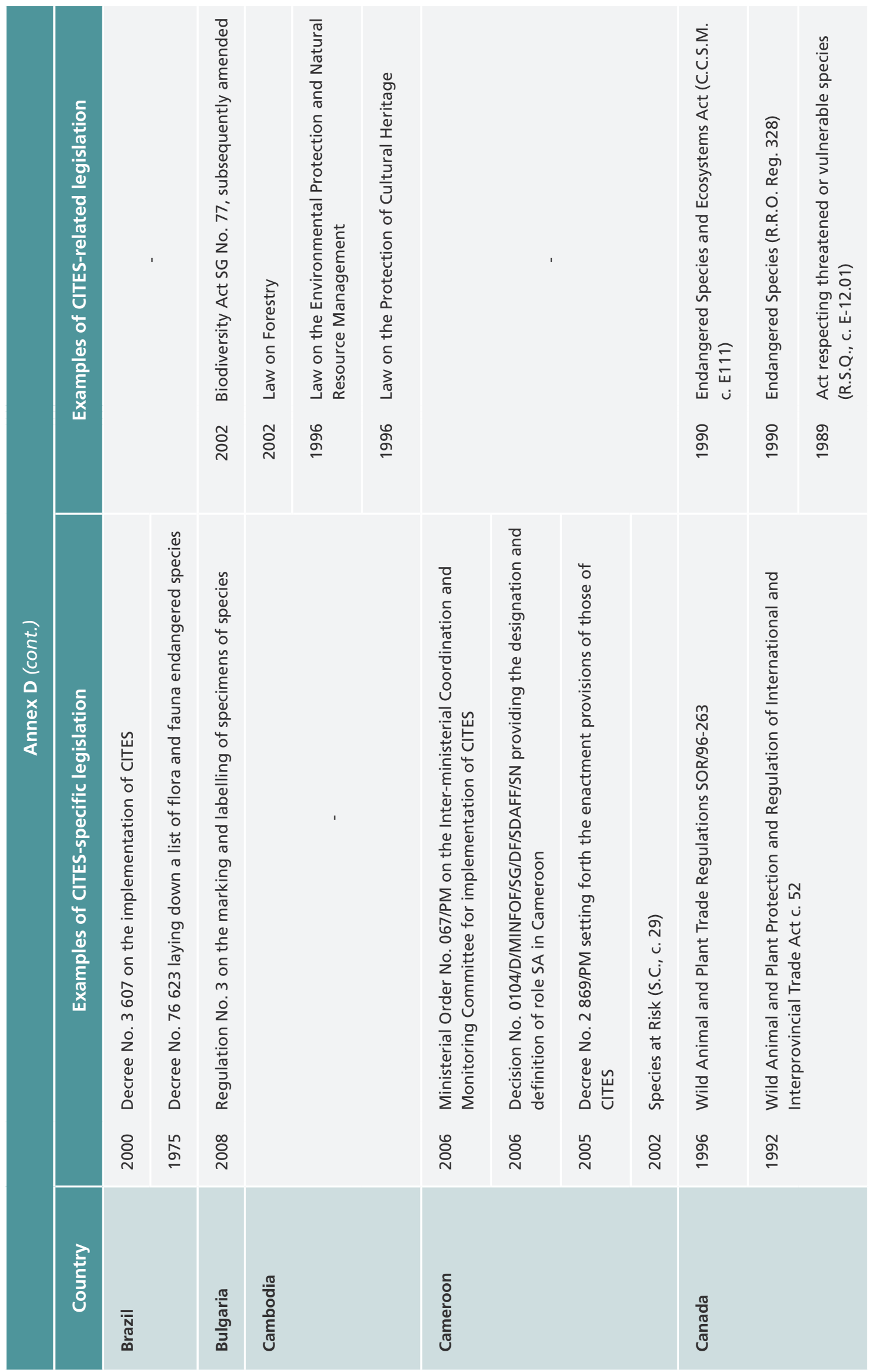




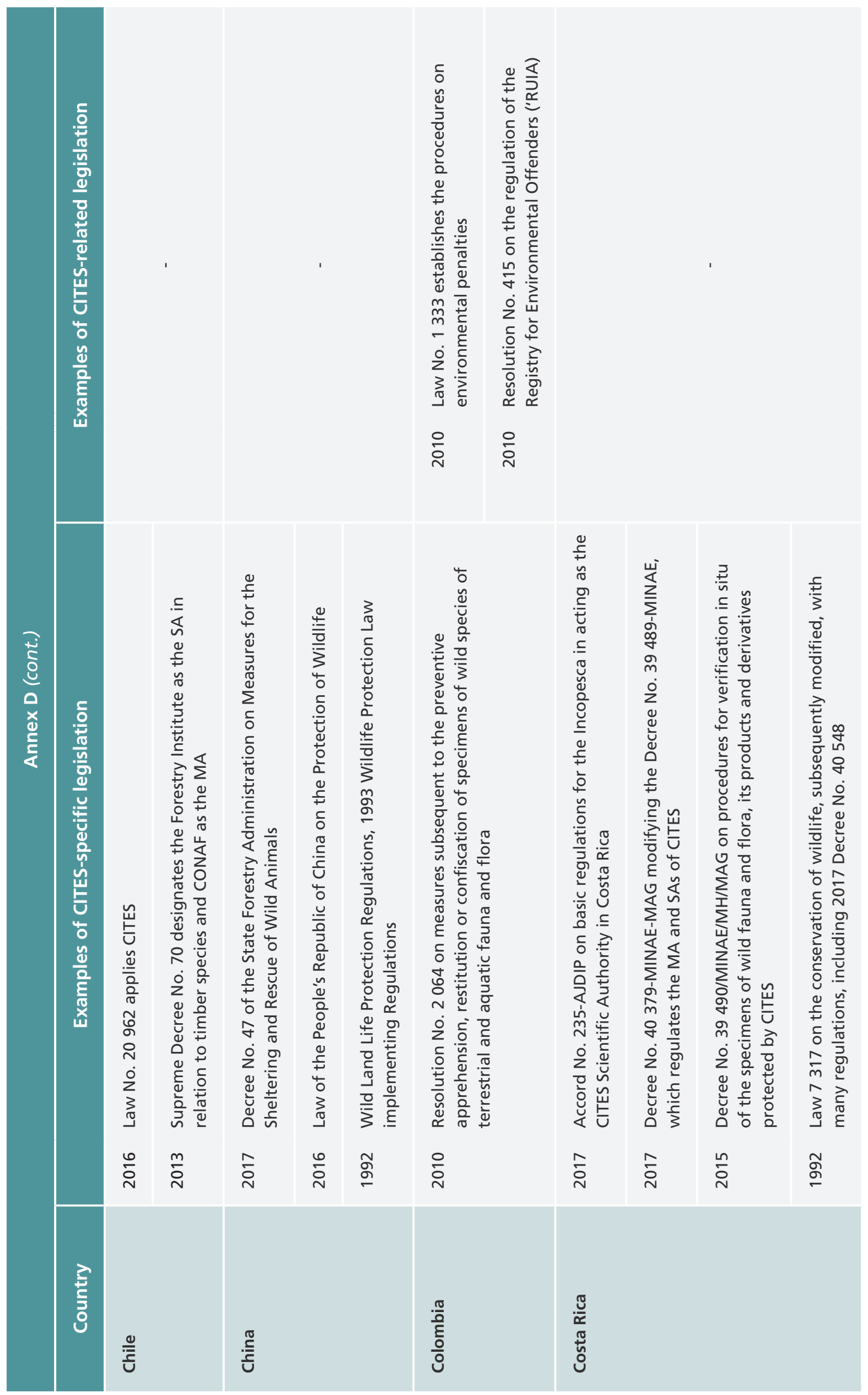




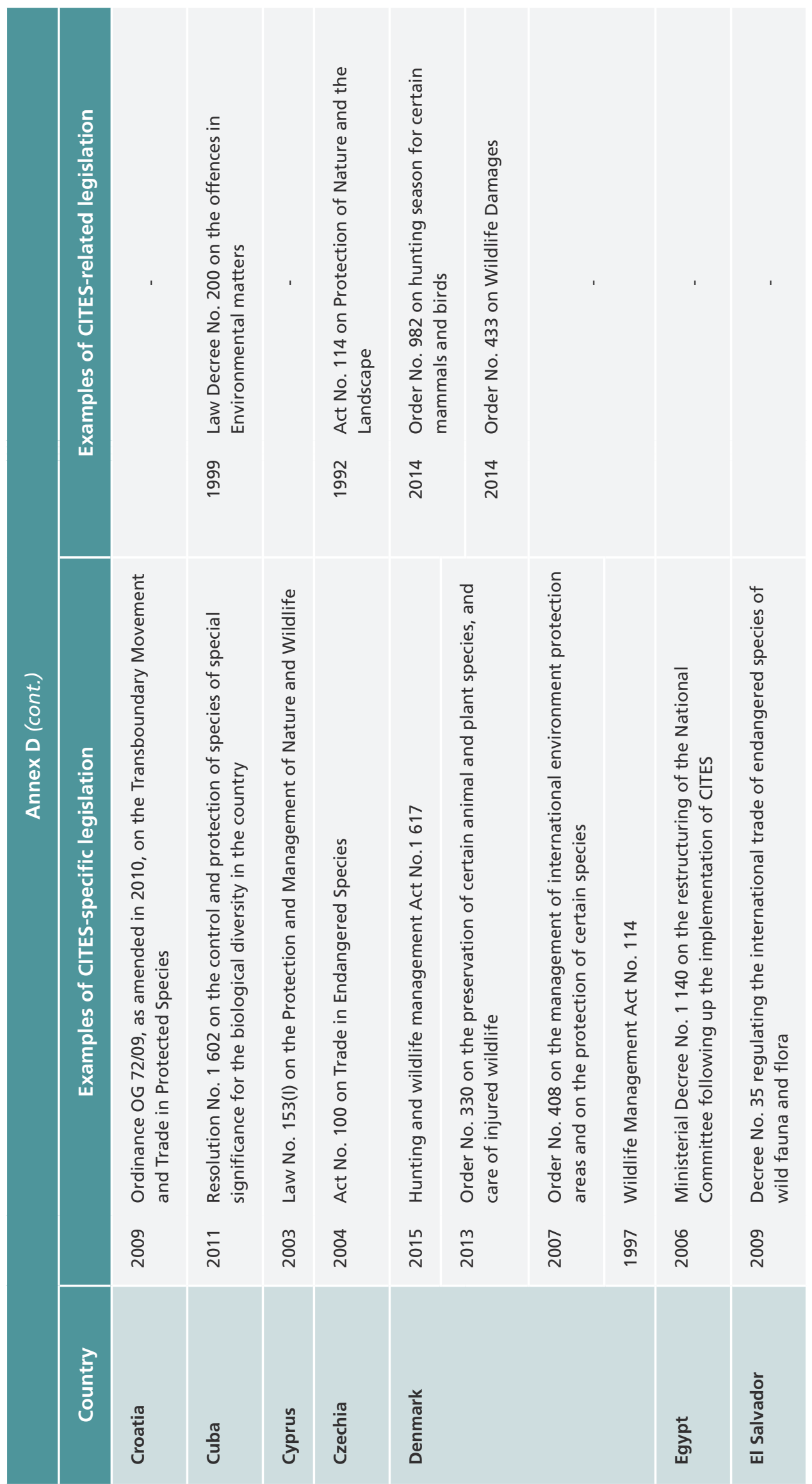




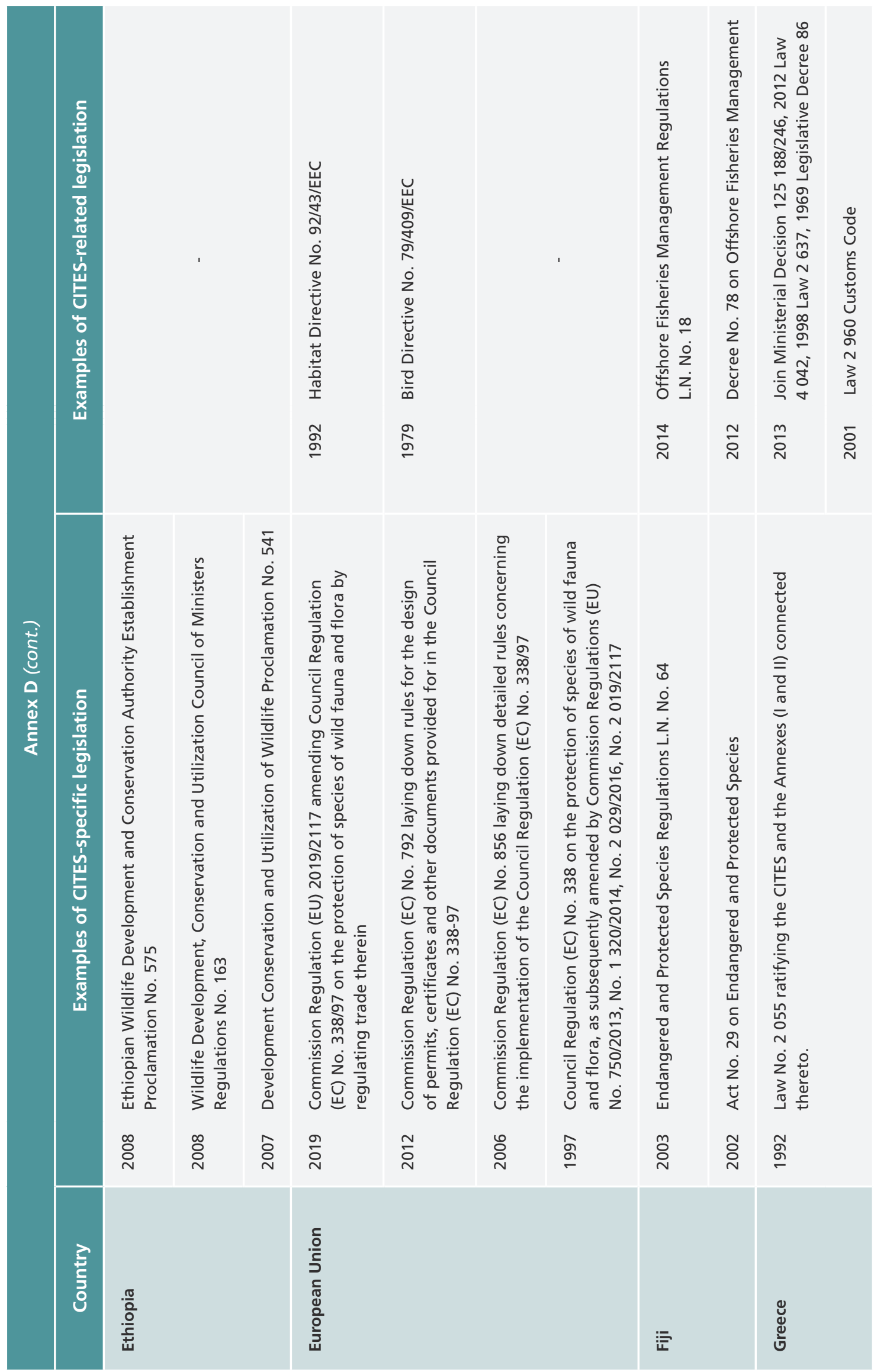




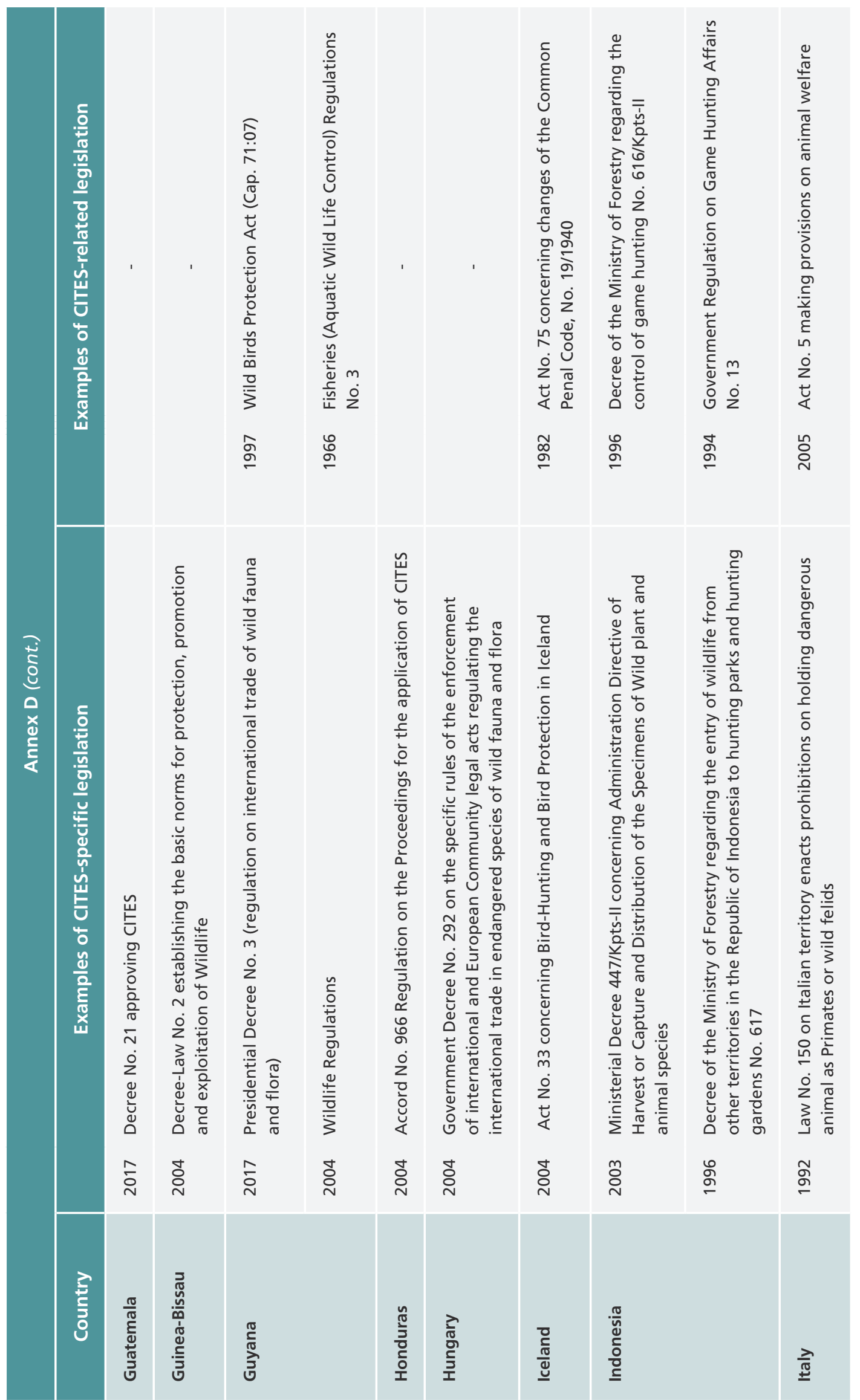




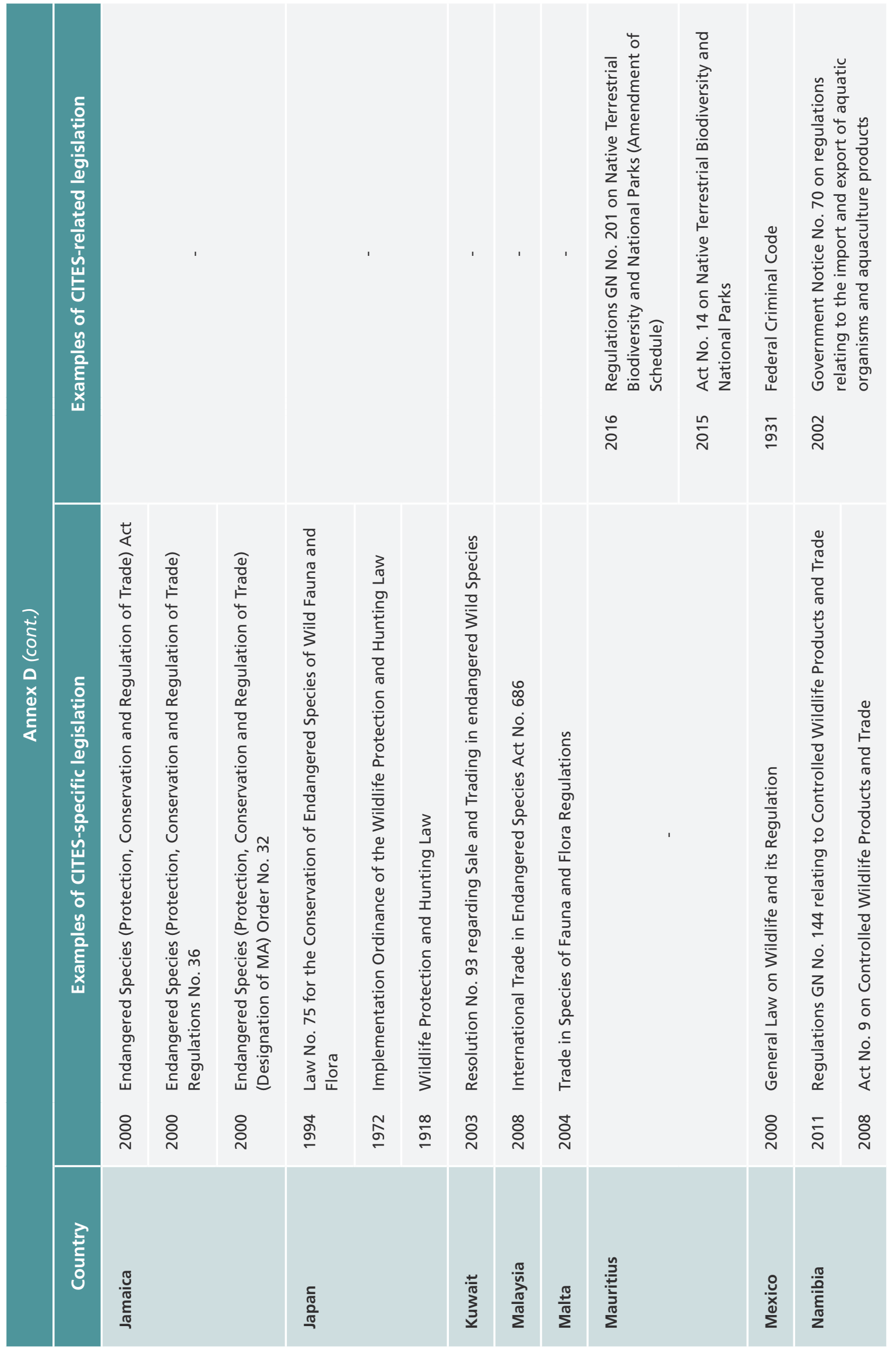




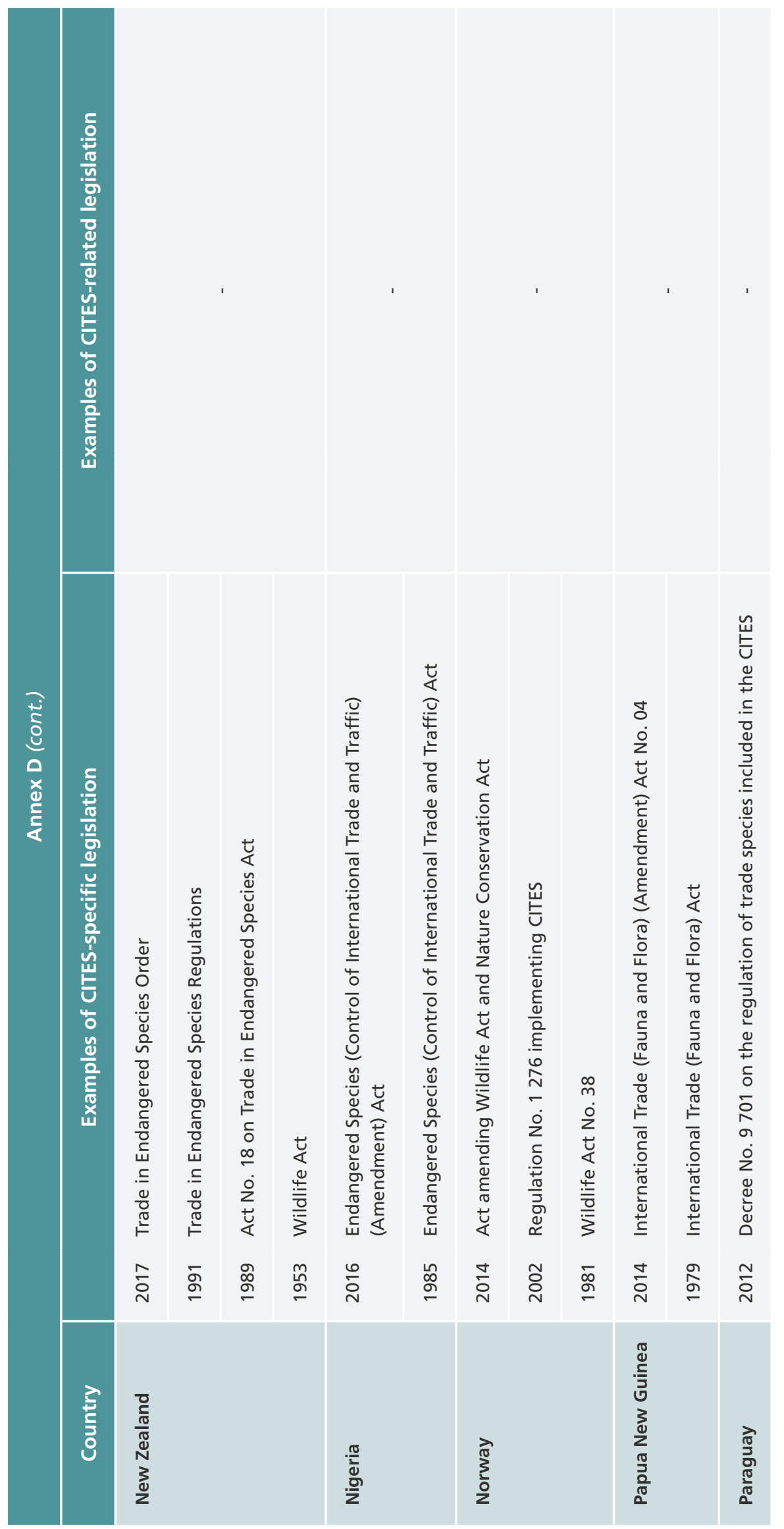




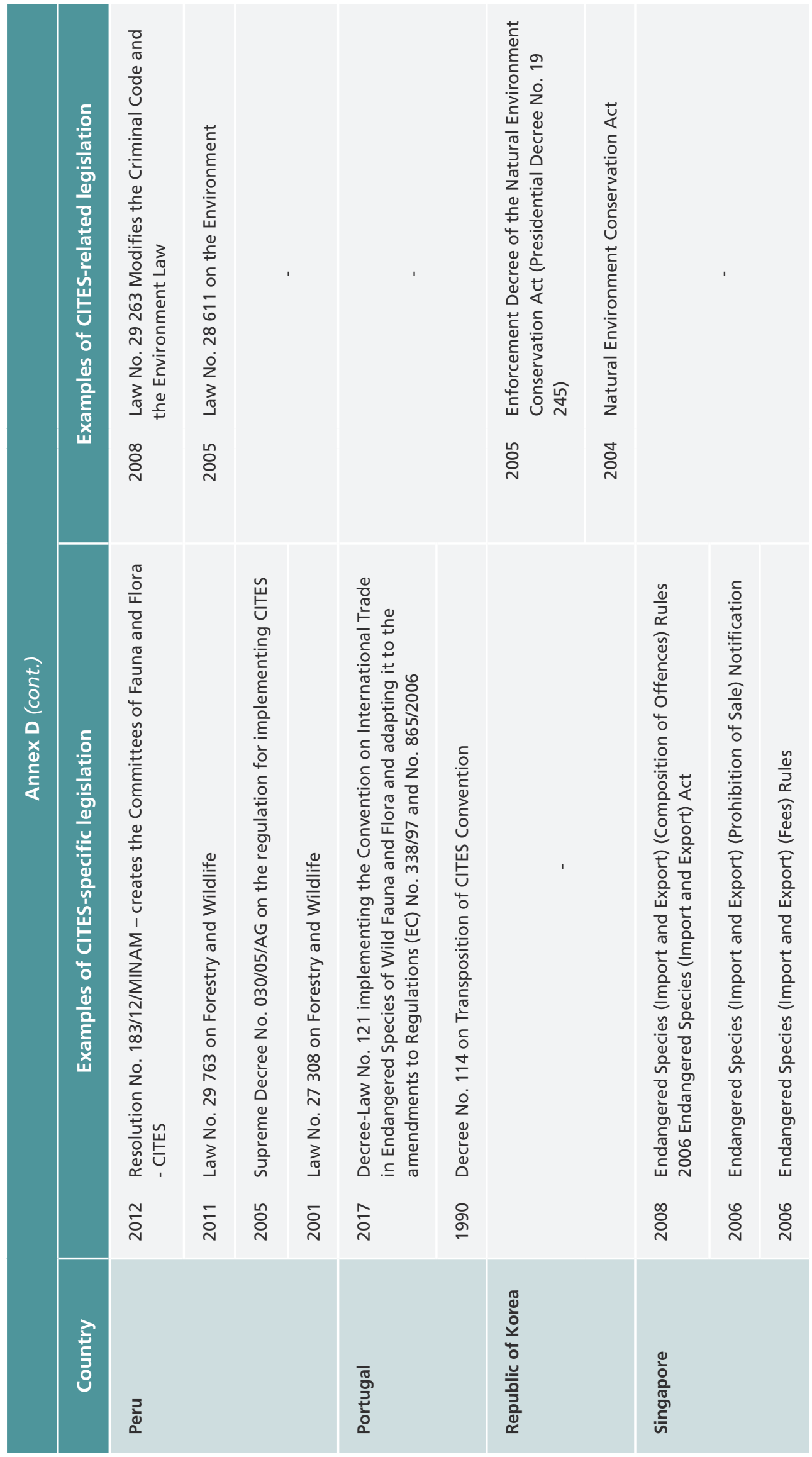




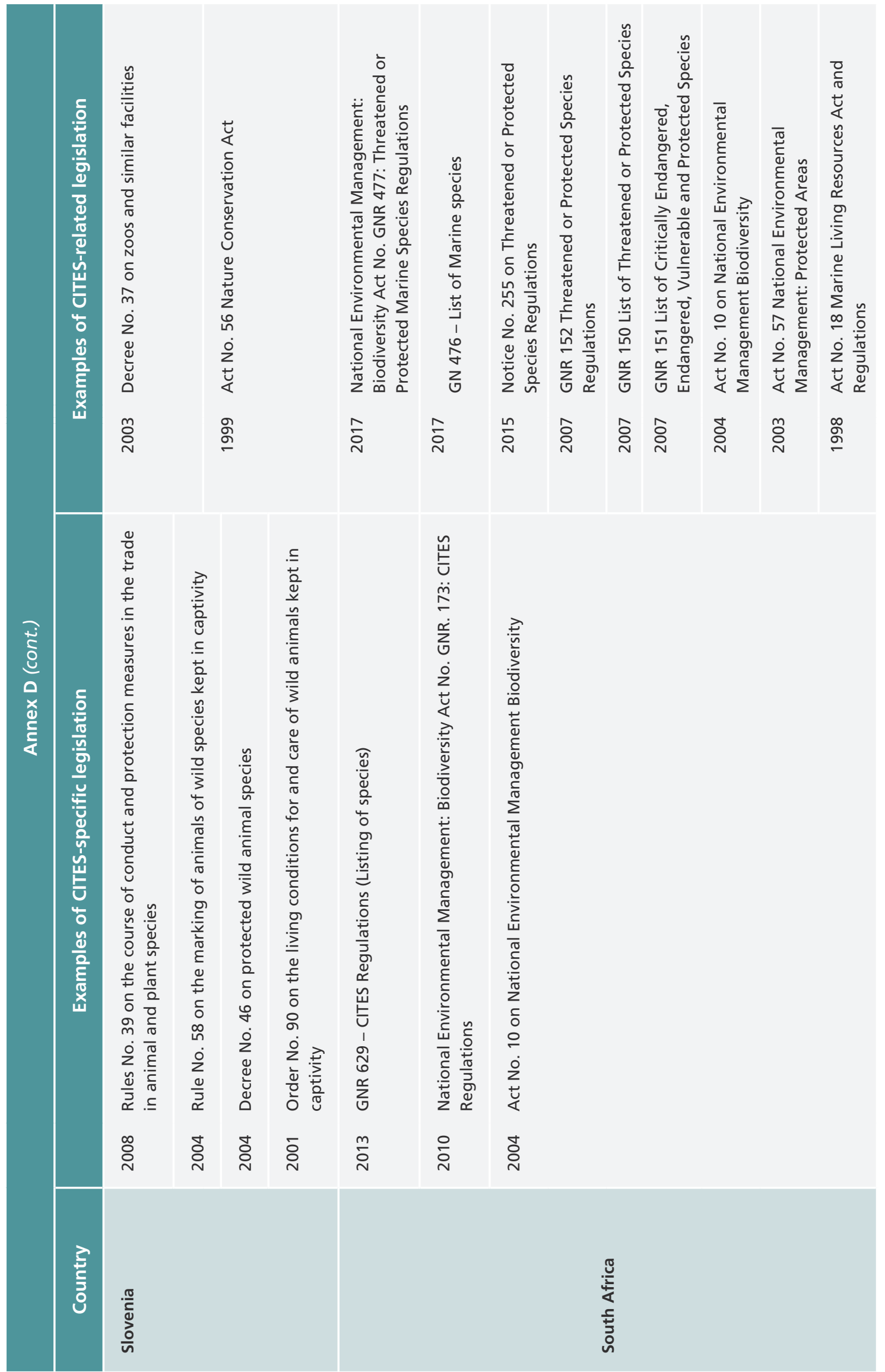



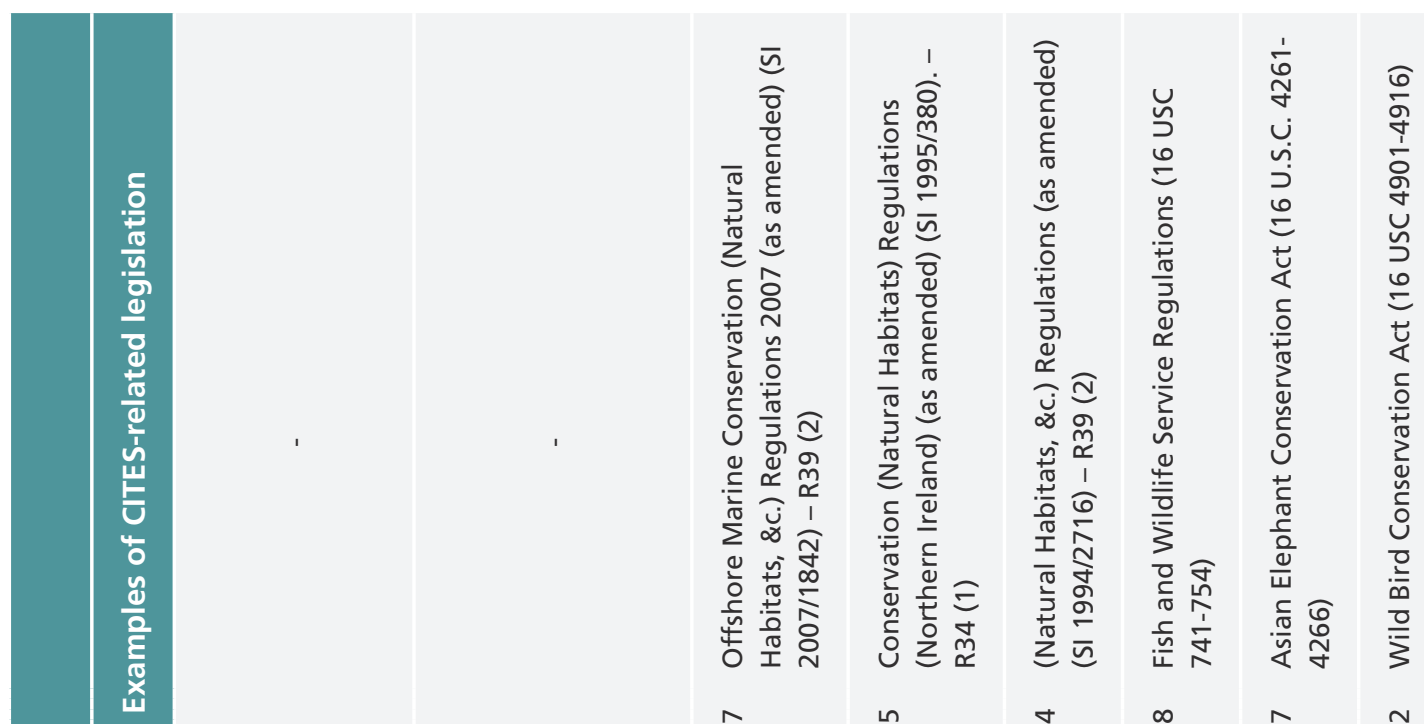

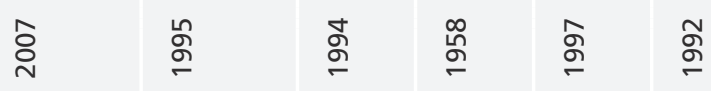

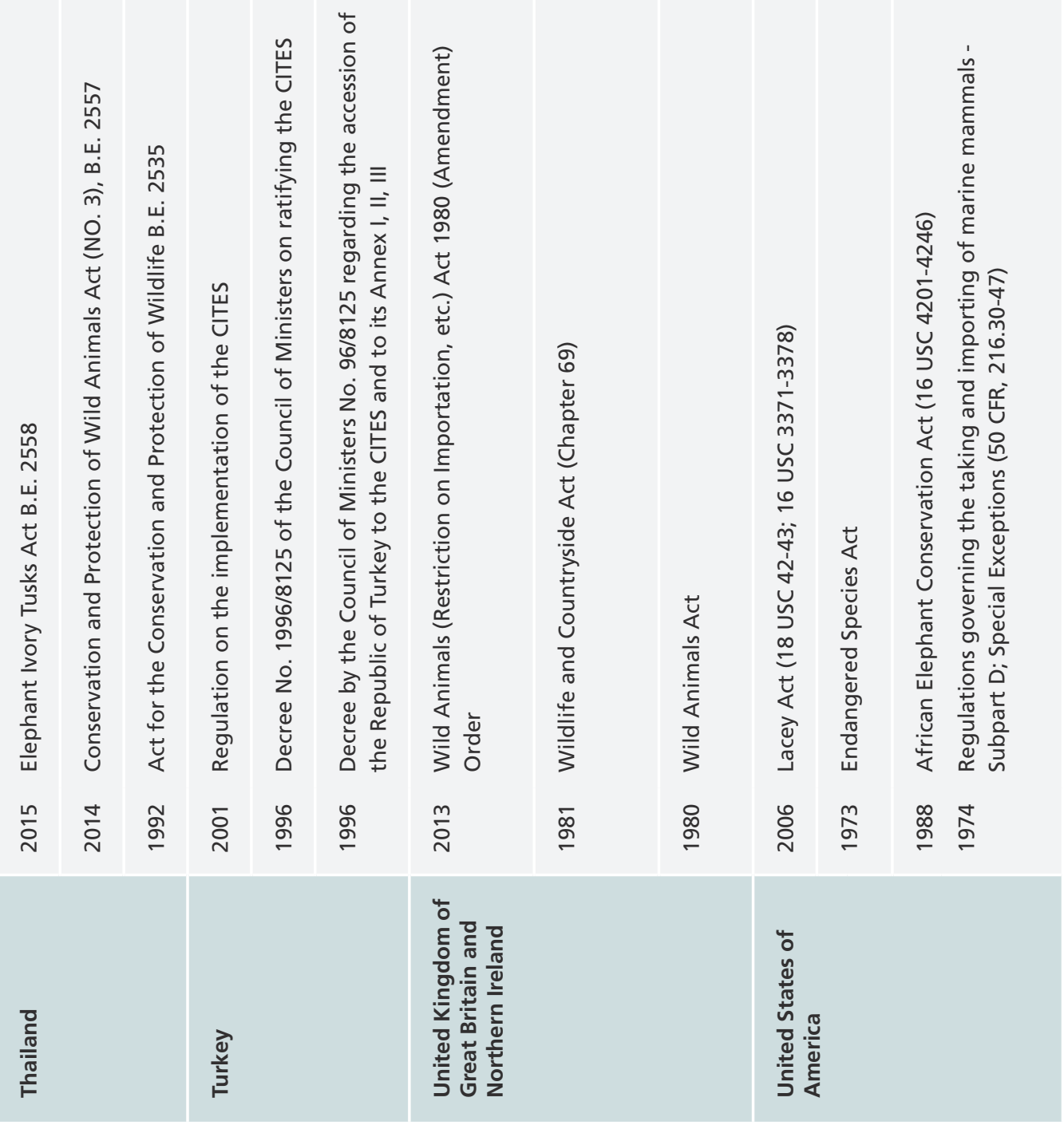




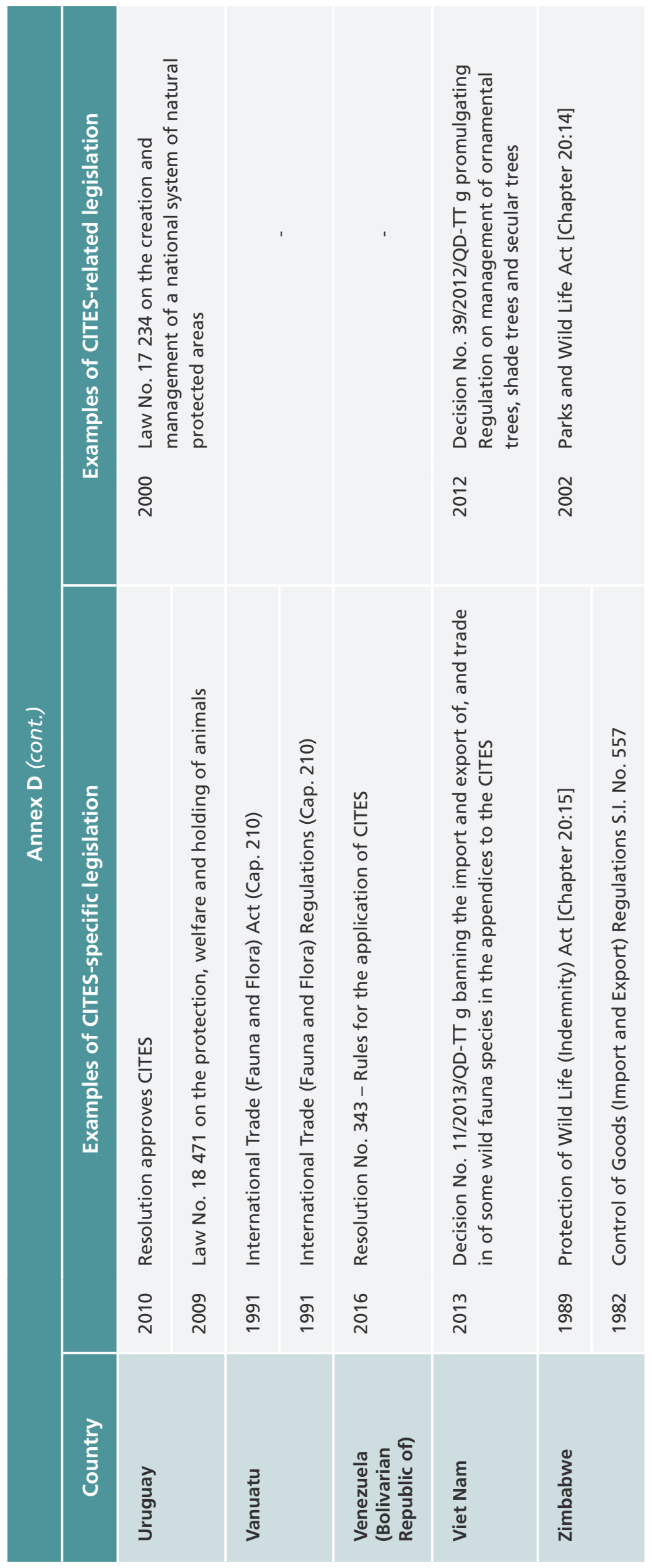




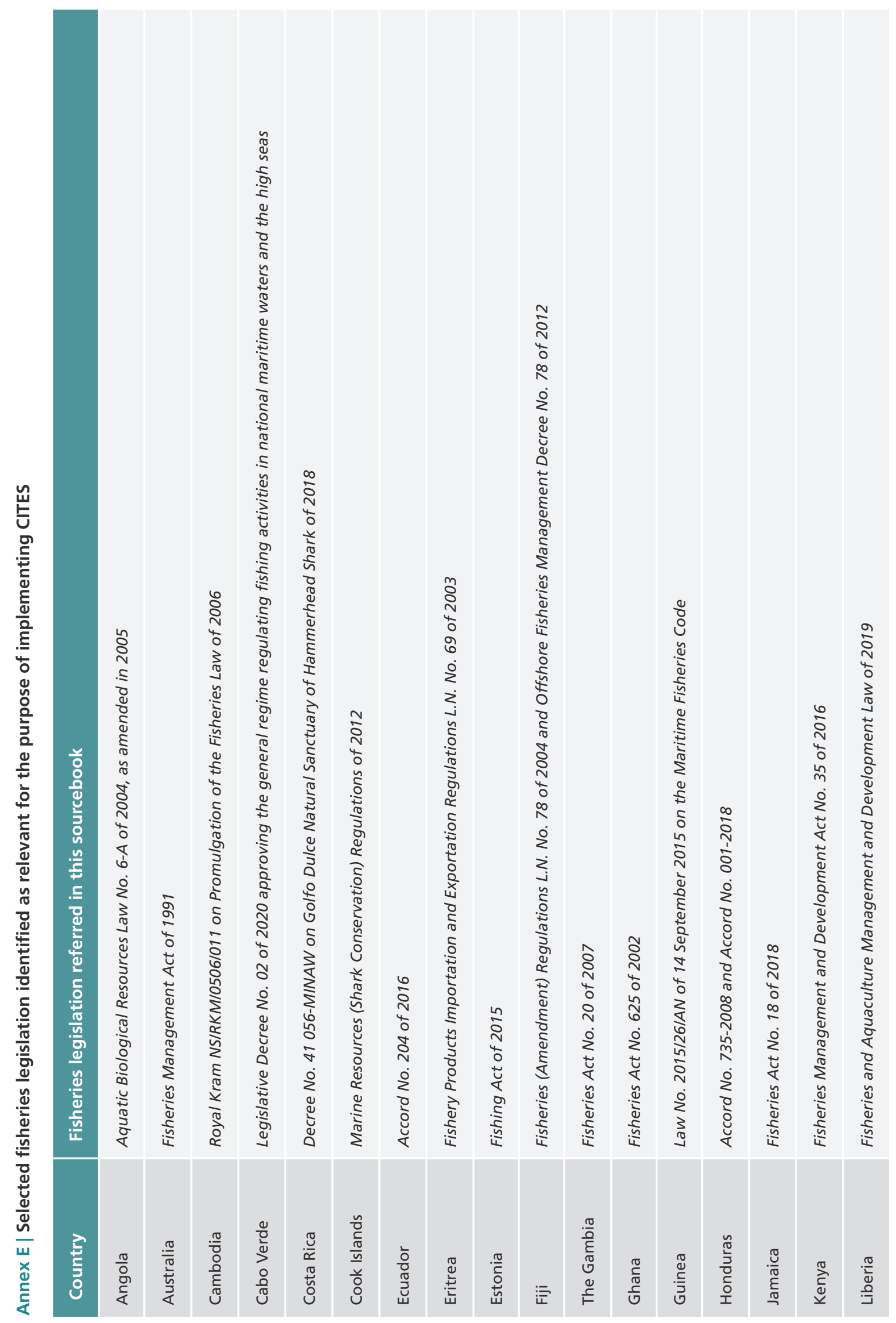




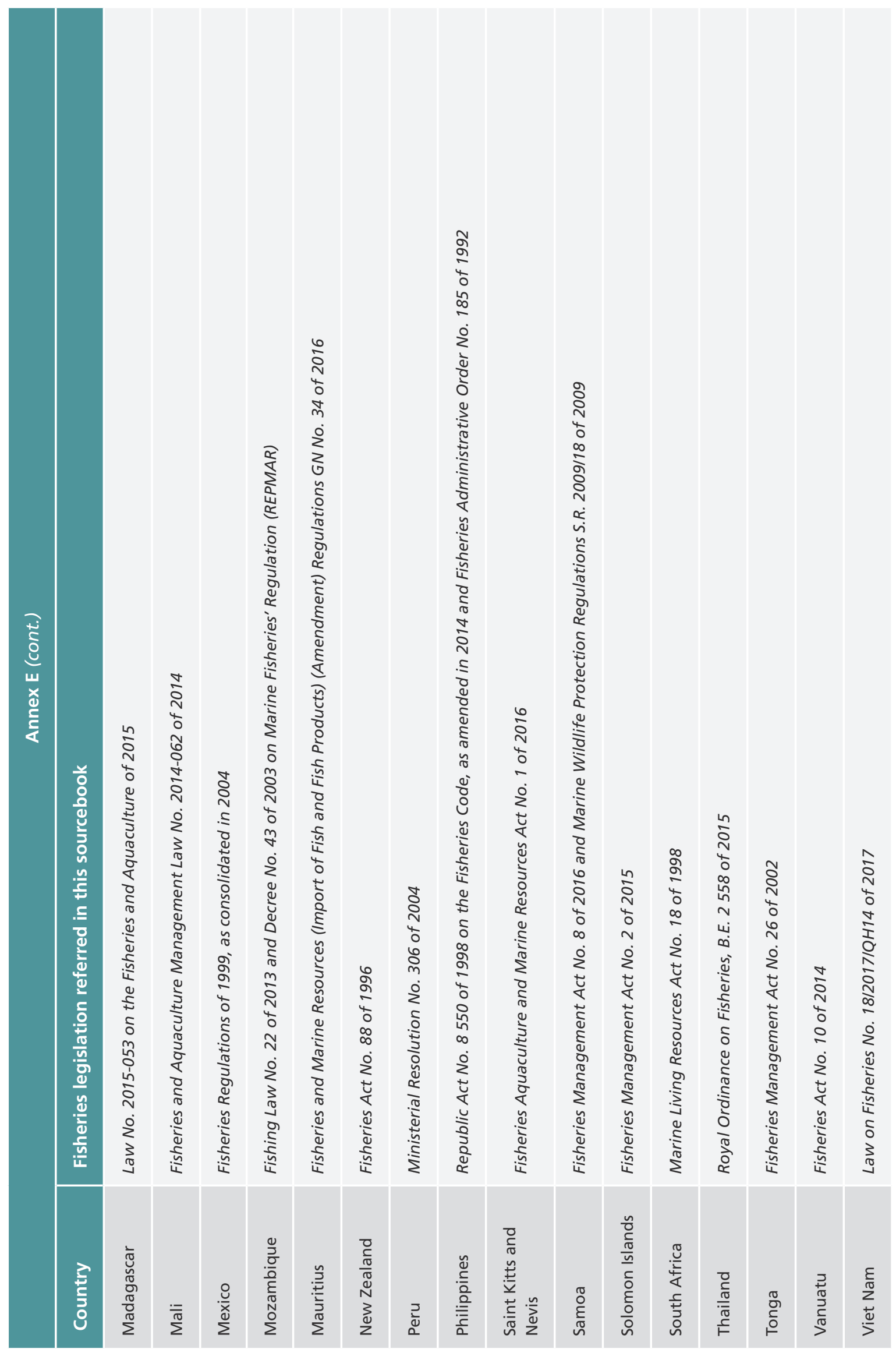




\section{GUIDE}

A guide on implementing CITES through national fisheries legal frameworks 



\section{Contents Guide}

A guide for implementing CITES through national fisheries legal frameworks

$\begin{array}{lr}\text { 1. Scope and structure } & 85\end{array}$

\begin{tabular}{lr}
2. & Purpose \\
\hline
\end{tabular}

3. The CITES National Legislation Project 87

3.1 Legislation for CITES implementation 88

3.2 Considerations for the National Legislation Project in addressing fisheries issues 89

4. Other FAO legal guides and tools for reviewing and strengthening fisheries legal frameworks 90

5. Preliminary considerations 93

5.1 First step: verifying the status of the country in relation to CITES 94

5.2 Second step: identifying CITES-specific legislation and relevant fisheries legislation 94

5.3 Third step: analysing key elements in the selected legislation 95

$\begin{array}{ll}5.4 & \text { Fourth step: ensuring coherence in selected legislation } \\ \end{array}$

6. Legislative options for implementing CITES through national fisheries legal frameworks 103

6.1 Part I: Preliminary 103

6.2 Part II: Administration 107

6.3 Part III: Management 111

6.4 Part IV: Monitoring, Control and Surveillance 116

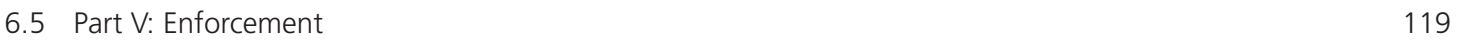

$\begin{array}{ll}\text { 6.6 Part VI: Regulations } & 121\end{array}$

Summary table of legislative options for implementing CITES through national fisheries legal frameworks

References

Figures

\begin{tabular}{ll} 
Box & National Legislation Project's (NLP) categorization of countries \\
\hline 7
\end{tabular}

Table $\quad$ Typical structure of a national fisheries primary legislation 91

Figure Guide to implementing CITES through national fisheries legal frameworks 102 



\section{A guide for implementing CITES through national fisheries legal frameworks}

\section{Scope and structure}

The second component of this sourcebook - the guide - is a practice-oriented toolkit focusing on implementing CITES through national fisheries legal frameworks. Adopting a broad and holistic approach, this guide outlines the main considerations and key elements to be identified and evaluated in national legal and/or policy frameworks with a view to ensuring that they contribute to the implementation of the objectives and requirements of CITES, especially by the relevant stakeholders in fisheries management. It also includes requirements stemming from CITES Resolutions that are not legally-binding on parties. This guide goes beyond the implementation of CITES, taking into account other relevant legally-binding and non-legallybinding instruments, principles and approaches. The guide is addressed to all States, whether or not they are a party to CITES. The guide may be used by a non-party which may not wish to implement CITES in its entirety, but is interested in specific aspects of it, in particular with respect to the listing of aquatic species.

The guide outlines the main considerations for countries in reviewing options for strengthening the implementation of CITES through their national fisheries legislation and, where appropriate, policy instruments. It draws upon the study forming the first part of this document but can be used as a standalone reference by those stakeholders who are already familiar with the interactions between the CITES regime and the fisheries sector. Section 6 provides detailed guidance on how to incorporate relevant provisions of CITES into national fisheries legislation. The legislative options presented in this guide are summarized and represented in tabular format in the Annex to this guide.

It is worth emphasizing that the decisions as to whether or not the fisheries sector should be more active and play a greater role in the implementation of CITES, and whether or not fisheries legislation should reflect and/or complement CITES requirements are the prerogative of States. It is posited, however, that global, regional and national practices demonstrate a certain level of acceptance on the part of States with implementing selected CITES requirements in the fisheries sector and through related national legislation. This is confirmed by the review undertaken in the formulation of these guidelines.

\section{Purpose}

The guide has the following specific purposes: to assess a particular country's legal framework; to verify whether the relevant CITES requirements have been adequately put in place, and to ensure that CITES requirements are acknowledged, observed, monitored, enforced and reinforced by the fisheries sector, particularly where a deliberate policy decision has been taken to pursue these purposes. Given that some countries have already implemented CITES through their own specialized fisheries legislation, the guide, in an effort to illustrate best practice, also provides references to actual examples of fisheries or fisheries-related legislation, demonstrating their approach, the style of drafting or particular phraseology used. It also has a section on the options that can be considered and used in ensuring sustainable fisheries and which can be reflected in national fisheries legal frameworks. 
The legislative implementation at national level of international instruments (whether or not legally-binding international instrument) through national legislation - is crucial in giving them practical effect and rendering enforceable any minimum requirements or standards enshrined in such instruments. Parties may implement international instruments by enacting primary legislation (e.g. a law, act, statute, ordinance or code), which establishes a broad, enabling legal framework, which may be further elaborated by secondary legislation (e.g. a regulation, decree, ministerial ordinance or rules). In certain countries, exceptionally, the legislation may elucidate both legal requirements and policy directives. An example is Brazil, which has its principal fisheries federal law simultaneously providing for the National Policy on Sustainable Development of Fisheries and Aquaculture as well as regulating fishing activities. ${ }^{1}$

Other subject-specific legislation may also play a role in the implementation of CITES or may cut across the natural resources extraction sector, including legislation purporting to regulate trade, crime, customs, the environment or biodiversity. Sector-specific legislation governs a particular sector, such as fisheries, and may deliberately or inadvertently influence the management, conservation and international trade of species. This is because the activities are impacting or may potentially impact on the survival or health of species of wild fauna and flora. In this context, subject-specific or sector-specific legislation should not replace the existing CITESspecific legislation, but should play a complementary role to it in the implementation of CITES.

A decision at governmental level to consider complementing or supporting the implementation of CITES in the fisheries sector, including through national fisheries legislation and policy, should be largely made on the basis that it would add value to the country's implementation efforts. Securing the implementation CITES through national legislation in particular can assist in the achievement of the objectives of CITES. Such a decision could foster the improvement of the country's fisheries legal framework in two ways. First, by ensuring comprehensiveness through the provision of more detailed requirements relating to the implementation of CITES. Second, by enabling the adoption or emulation of certain approaches and legislative texts required by or recommended for CITES implementation as regards commercially exploited and managed CITES-listed aquatic species.

The guide takes into account the fact that certain countries may have both CITES-specific legislation and fisheries legislation relevant to CITES, but that such legislation is not sufficiently compatible or complementary, thus creating legal uncertainty, incoherence and potential conflicts in the interpretation and application of the law. In this context, the guide can play a vital role in ensuring consistency between CITES-specific and CITES-related fisheries legislation and be a useful tool in addressing the problems caused by conflicting provisions that unintentionally hinder the implementation of CITES.

The guide emphasizes that the starting point in implementing CITES through fisheries legislation begins with a review of the party's CITES-specific legislation using the guidelines and recommendations contained within the National Legislation Project. The guide does not seek to diminish or replace the existing initiative of the CITES regime in implementing it through national legal frameworks. It is intended to have a significant complementary function in light of the guidance already available and activities already undertaken for CITES implementation.

See Brazil. Law No. 11959 of 2009, which provides for the National Policy on Sustainable Development of Fisheries and Aquaculture, regulates fishing activities and other matters. 


\section{The CITES National Legislation Project}

During CoP8, in 1992, the parties agreed on measures for enhancing CITES implementation through their respective legal systems by establishing the National Legislation Project (NLP) (CITES, 1992). Work undertaken as part of the NLP has provided guidance for the development of national legal frameworks to support the implementation of CITES, including the use of the CITES Draft Model Law on International Trade in Wild Fauna and Flora (hereafter referred to as "Model Law") (CITES, n.d-c), the legislative checklist and a questionnaire for legal drafters (CITES, n.d-b). Through the NLP, the CITES Secretariat analyses the parties' legal implementation based on an evaluation of four minimum requirements (see Box), assisted by the Standing Committee in a monitoring role (CITES, 1992).

National Legislation Project's (NLP) categorization of countries

\begin{tabular}{|l|c|c|c|}
\hline \multicolumn{1}{|c|}{ Minimum Requirements } & Category 1 & Category 2 & Category 3 \\
\hline $\begin{array}{l}\text { 1. Designation of at least one MA and } \\
\text { one SA }\end{array}$ & $\checkmark$ & X \\
\hline $\begin{array}{l}\text { 2. Prohibiting trade in specimens that } \\
\text { contravenes CITES }\end{array}$ & $\checkmark$ & $\begin{array}{c}\text { Not all nor } \\
\text { none. At least } \\
\text { one minimum } \\
\text { requirement }\end{array}$ & $\mathrm{X}$ \\
\hline 3. Penalizing such trade & $\checkmark$ & $\mathrm{X}$ \\
\hline 4. Confiscation of specimens illegally traded or \\
possessed
\end{tabular}

Based on this analysis, a party's legislation is placed in Category 1 if it is "believed generally" to meet all four requirements, in Category 2 if it meets at least one such requirement, or in Category 3 if it is believed to meet none of them (CITES, 2019a). According to the legislative status of parties in respect of CITES as at November 2019, there are 102 parties with legislation in Category 1, 44 in Category 2 and 29 in Category 3 (CITES, n.d-d). The Standing Committee has identified 20 parties with legislation in Categories 2 and 3 that require its prioritized attention (CITES, 2019b). ${ }^{2}$ With respect to countries whose legislation is considered as in need of improvement, most of them, including those in Category 3, are located in Africa. ${ }^{3}$

The CITES Secretariat has been cooperating with the UNEP in supporting countries, mainly in Africa, to improve the quality of their legislation with a view to elevating their positions to Category 1. These include countries in Category 2 (Eritrea and The Gambia) 4 and 3 (Niger and Somalia). Since 2016, the CITES Secretariat has also provided assistance other countries, including Benin, Comoros, Côte d'Ivoire, Mauritania, Niger, Togo. This Secretariat's support is

\footnotetext{
Countries involved are: Algeria, Botswana, Congo, Ecuador, Guinea, India, Kazakhstan, Kenya, Mozambique, Pakistan, United Republic of Tanzania and Uzbekistan (Category 2) and Belize, Comoros, Djibouti, Lao People's Democratic Republic, Liberia, Mauritania, Rwanda and Somalia (Category 3).

3 In addition to the mentioned countries, others are Afghanistan, Armenia, Bhutan, Bosnia and Herzegovina, Cabo Verde, Central African Republic, Côte d'Ivoire, Dominica, Ghana, Grenada, Lesotho, Libya, Niger, Oman, Palau, Samoa, Sao Tome and Principe, Seychelles, Sierra Leone, Sri Lanka, Eswatini (formerly Swaziland), Syrian Arab Republic and Uganda.

4 According to the information obtained in the CITES Expert Workshop and the follow-up activities, by May 2019 draft laws of these two countries as well as of the Solomon Islands are being processed. Work on CITES legislation with Lesotho and Somalia remains ongoing.
} 
also provided to parties that have recently acceded to CITES such as Angola, which enacted its CITES-related legislation in 2018 and was subsequently placed in NLP Category 1 (CITES, 2018).

The assistance provided under the NLP is significant, as it has led to the development and enactment of legislation to implement CITES in countries where CITES implementation and species protection was either inadequate or non-existent. The analysis provided in this guide, and the options provided, emulate, to some extent, the approach adopted by the NLP. The guide and its recommendations focus on how national fisheries legal frameworks can, where appropriate, complement the principal CITES legal framework in supporting the implementation of CITES in the fisheries sector.

\subsection{Legislation for CITES implementation}

The legislation of the 102 parties placed in Category 1 meets the four requirements of CITES. It is unclear which particular legislation is aligned with CITES and whether this also includes fisheries-specific legislation. In order to better appreciate this issue, research was undertaken using three main electronic databases. This research examined the reports submitted over the last five years by the parties to the Secretariat, particularly their legislation for implementation and enforcement of CITES ${ }^{5}$, CITES-related legislation located within the ECOLEX database ${ }^{6}$ and in the FAOLEX database. ${ }^{7}$ This research approach aspired to determine which legislation has been indicated by parties as supporting CITES implementation. Several legislative instruments were found, mainly CITES-specific legislation, with only very few of them including references to fisheries-specific legislation such as in Fiji, Iran (Islamic Republic of), Guyana and the United States of America ${ }^{8}$. A list with selected countries classified in NLP Category 1 and their respective CITES-specific and CITES-related legislation is presented in Annex D of the study.

A more in-depth analysis of the relevant national legislative frameworks could lead to the identification of areas that could be strengthened in order to ensure consistency, coherence or complementarity with CITES-specific legislation, but such an endeavour is beyond the scope of this guide. Examining the national implementation reports submitted by parties every three years, with their respective initiatives on CITES legal implementation, could also provide further guidance on how to legislate for and implement CITES within the fisheries sector.

In this guide, a distinction is made between CITES-specific legislation and CITES-related legislation. CITES-specific legislation refers to a legal instrument which may be designated as such and covers the regulation of international trade in specific species of animals and plants. It may generally refer to wildlife, wildlife use, exploitation, conservation, management and/or protection, but it must cover the international trade in CITES-listed species. It may also specifically refer to the implementation of CITES, or any CITES-related issue, such as the establishment of MA, SA, provisions on marking of specimens, confiscation, etc. CITES-related legislation generally regulates forestry, fisheries, aquaculture, biodiversity, environment, domestic crimes, cultural heritage etc. and will not necessarily have a title expressly referring

\footnotetext{
This was found in the CITES website repository. See CITES, n.d-a.

ECOLEX, the gateway to environmental law. See search results for legislation related to CITES (ECOLEX, 2020).

FAOLEX, a FAO legislative database is the world's largest database for food and agriculture legislation including legislation on fisheries and aquaculture, forests, land and water (FAO, 2020)

8 Fiji. Offshore Fisheries Management Decree No. 78 of 2012 and Regulations L.N. No. 18 of 2014 on Offshore Fisheries Management; Guyana. Regulations No. 3 of 1966 on Fisheries (Aquatic Wild Life Control); Iran (Islamic Republic of). Law of 1967 on Hunting and Fishing, and Regulation of 1968 on Hunting and Fishing; United States of America. Regulations of 1974 governing the taking and importing of marine mammals - Subpart D, Special Exceptions (50 CFR, 216.30-47) and the Fish and Wildlife Service.
} 
to the matters covered by the CITES-specific legislation. In this respect, all fisheries legislation could be regarded as CITES-related legislation as long as it covers elements of international trade in CITES-listed species.

\subsection{Considerations for the National Legislation Project in addressing fisheries issues}

In some countries, international trade activities (not necessarily all CITES transactions, but mainly the export and import of fishery products) are regulated by fisheries legislation, including both primary and secondary legislation. For example, in Tonga, the Fisheries Management Act of 2002 contains provisions on the export of fish and on illegal import of fish, and in Madagascar, the Fisheries and Aquaculture Law of 2015 provides general rules or standard provisions on export and import of fishery products which can be found in many fisheries legislation. ${ }^{9}$ These are examples of primary fisheries legislation. There are also, however, examples of secondary fisheries legislation, which are entirely devoted to international trade matters. Examples of these are Eritrea's Fishery Products Importation and Exportation Regulations 2003 L.N. No. 69 of 2003, and Mauritius' Fisheries and Marine Resources (Import of Fish and Fish Products) (Amendment) Regulations GN No. 34 of 2016.

Certain aspects of the international fisheries trade may thus be addressed in both national fisheries legislation (primary and secondary) and in CITES-specific legislation. The fisheries legislation containing provisions on international fisheries trade would not normally require special care for selected fish species that might potentially be threatened by such trade. Consequently, CITES-specific legislation would provide stricter requirements and would complement the fisheries legislation with more detailed provisions.

The problem of having both fisheries legislation and CITES-specific legislation regulating the same matter is that each legislation may not make any reference to the other, creating the risk of duplication of requirements and of conflicting provisions (despite addressing different right-holders and duty-bearers) and an inconsistent and incoherent legal framework. It may also create institutional conflict by empowering separate entities to have authority over the same subject matter (e.g. issuance of import, export or re-export certificates). Additionally, the fisheries sector may not be aware of CITES legislation and its application to the international trade of aquatic species that the sector exploits and manages. Likewise, CITES authorities may not be aware of applicable fisheries legislation that regulates the same international trade transactions for fish species listed in the CITES Appendices. In practice, this disconnection complicates the implementation and enforcement of the applicable legislation which in turn hinders the achievement of effective outcomes.

Given that the NLP is dedicated to the general implementation of CITES, including but not limited to, its implementation in the fisheries sector, it is important to emphasize certain preliminary considerations that may be useful for improving the efficacy of CITES-specific legislation in a given country. It is fundamentally important, for instance, that the ongoing work devoted to general CITES implementation through legal frameworks takes special

\footnotetext{
9 Tonga. Fisheries Management Act No. 26 of 2002; Madagascar. Law No. 2015-053 on the Fisheries and Aquaculture of 2015. Note that this Madagascar 2015 Fisheries and Aquaculture Code prohibits, at all times and in all places, in accordance with national legislation and international conventions ratified by Madagascar, the fishing, taking, possession and trading of threatened and protected species, corals, marine mammals, seabirds, marine and freshwater turtles and any listed aquatic species in respect of which conservation measures have been adopted (Article 18).
} 
account of the fisheries sector due to the increasing number of commercially exploited and managed aquatic species being listed in CITES Appendix II. Consequently, when preparing, drafting or working to improve CITES-specific legislation in a particular country, it would be important for that country to consider:

(i) an analysis of the existing fisheries legal framework that may already regulate certain aspects of international fisheries trade in CITES-listed aquatic species;

(ii) an evaluation of the extent to which that legislation addresses CITES requirements and to which it could adequately support, complement and strengthen implementation;

(iii) the appropriate incorporation, when drafting CITES-specific legislation, of the key fisheries elements for CITES (see Subsection 5.3);

(iv) communication and coordination with the FA or any other relevant authority in the country to ensure that it is well-informed about CITES and the implications for the fisheries sector; and

(v) promoting the awareness by or of the fisheries sector, especially the national authority responsible for fisheries matters, to ensure that it is informed and properly guided on the use and operation of all applicable CITES-specific and fisheries-related legislation in its international trade context.

\section{Other FAO legal guides and tools for reviewing and strengthening fisheries legal frameworks}

This guide draws from the work and experience of FAO in the preparation of legal studies and papers (FAO, n.d) as well as the reviews and strengthening of legislation undertaken in many countries (FAO, 2019a; FAO, 2007). Specific reference will be made to the 2016 "A How-to guide on Legislating for an Ecosystem Approach to Fisheries" (hereafter referred to as the "How-to guide for an EAF") (FAO, 2016) and the 2019 "Step-wise guide for the Implementation of International Legal and Policy Instruments related to Deep Sea Fisheries and Biodiversity Conservation in ABNJ", which provide certain components of relevance for CITES implementation (FAO, 2019c).

The fisheries legal frameworks of many countries are consistent in their substance and form. Analysis of State practice reveals that a typical fisheries legal instrument will contain provisions concerning the use, planning, management, development, conservation, research, monitoring, control and surveillance (MCS), enforcement, and other miscellaneous matters related to fishing and fishing-related activities (FAO, 2016; Kuemlangan, 2009). Fisheries legislation usually provides for different types of fishing activities that are authorized by a licence or another permit system including subsistence, artisanal, semi-industrial and industrial fishing, and generally regulates inland and marine capture fisheries in any maritime zone as well as aquaculture.

The typical fisheries-related legislation structure is organized into six main parts, each corresponding to the "title" or "chapter" that would normally appear in fisheries primary legislation (see Table). These six parts are:

Part 1 ("Preliminary"). This part has provisions that may refer to the source of the law, such as the States' Constitution, or to the international law or agreement to be 
implemented. The provisions of this part also introduce what the fisheries legislation is about and establish its scope and objectives. It also elucidates the meaning of terms, concepts, principles, approaches and indicates how the administrator or user of the legislation should interpret them.

Part 2 ("Administration") typically establishes the institutional framework for fisheries management. It establishes or designates fisheries or fisheries-related institutions, agencies, offices or authorities, delineates their composition, competence, roles, rights, responsibilities and, where applicable, contains stipulations for the interaction between them and other institutions at different levels of governance.

Part 3 ("Management"). This part is normally the most substantive part of a fisheries legislation, regulating every aspect of the fisheries value-chain, from controlling access to fisheries to the sale and international trade in fish and fish products. It also addresses environmental aspects of conservation measures as well as monitoring, data collection, fisheries- (and aquaculture) related sanitation and health issues and research.

Part 4 ("Monitoring, Control and Surveillance") establishes and regulates schemes that enable authorized officers and observers to exercise their respective MCS activities, ensure their safety and regulate the control and reporting of fishing and fishingrelated activities.

Part 5 ("Enforcement") sets out the legal consequences for non-compliance with the fisheries legislation, and the particulars of applicable administrative and judicial procedures.

Part 6 ("Regulations") provides for the executive arm of government (the Minister) or the fisheries management authority (FA) with the mandate to regulate technical or operational aspects of fisheries management or to elaborate the issues already covered in the primary fisheries legislation.

\begin{tabular}{|c|c|c|}
\hline \multicolumn{3}{|c|}{ Typical structure of a national fisheries primary legislation } \\
\hline Part & Main Components & Nature of Provisions \\
\hline $\begin{array}{l}\text { I. } \\
\text { Preliminary }\end{array}$ & $\begin{array}{l}\text { - International } \\
\text { agreements which the } \\
\text { law implements } \\
\text { - Definitions/ } \\
\text { Interpretation } \\
\text { - Scope/ Application } \\
\text { - Principles/ Approaches/ } \\
\text { Objectives }\end{array}$ & $\begin{array}{l}\text { Provides definitions or interpretation, scope or } \\
\text { application, objectives and principles and/or approaches. } \\
\text { Broad objectives such as revenue generation, sustainable } \\
\text { development, ensuring food security and nutrition, } \\
\text { sustaining livelihoods and eliminating IUU fishing } \\
\text { are normally found under this part. Principles and } \\
\text { approaches such as the use of EAF and the precautionary } \\
\text { approach to fisheries are also found here. This part may } \\
\text { also refer to international agreements the country is a } \\
\text { party to or to conservation and management measures } \\
\text { adopted by a RFMO or other regional arrangements a } \\
\text { country is a party to which need to be implemented. }\end{array}$ \\
\hline
\end{tabular}




\begin{tabular}{|c|c|c|}
\hline \multicolumn{3}{|c|}{ Table (cont.) } \\
\hline Part & Main Components & Nature of Provisions \\
\hline $\begin{array}{l}\text { II. } \\
\text { Administration }\end{array}$ & $\begin{array}{l}\text { - Institutional } \\
\text { Arrangements } \\
\text { - Mandates and Powers } \\
\text { - Stakeholder } \\
\text { Participation } \\
\text { - Coordination, } \\
\text { cooperation and } \\
\text { integration } \\
\text { - International (global } \\
\text { and regional) } \\
\text { cooperation }\end{array}$ & $\begin{array}{l}\text { Provides for institutional arrangements, including the } \\
\text { identification of relevant institutions, officers or offices } \\
\text { and vesting powers and functionsfor policy development, } \\
\text { administration and management of fisheries. It may } \\
\text { provide for the establishment of, and participation } \\
\text { in, fisheries advisory committees or boards and their } \\
\text { roles, responsibilities or mandates, and mechanisms for } \\
\text { cooperation, consultation or coordination. }\end{array}$ \\
\hline $\begin{array}{l}\text { III. } \\
\text { Management }\end{array}$ & $\begin{array}{l}\text { - Catch/Output controls } \\
\text { - Input/Effort controls } \\
\text { - Moratoria/ } \\
\text { Prohibitions/ Other } \\
\text { controls on fishing } \\
\text { gears, method, spatial, } \\
\text { temporal controls } \\
\text { - Trade (including } \\
\text { export and import) } \\
\text { in fishery and } \\
\text { aquaculture products } \\
\text { - Fisheries management } \\
\text { plans / Listing of } \\
\text { species } \\
\text { - Conservation measures } \\
\text { - Fisheries monitoring } \\
\text { and research } \\
\text { - Access agreements } \\
\text { with other countries } \\
\text { for the purpose of } \\
\text { fishing by foreign } \\
\text { vessels in the coastal } \\
\text { State's territorial seas } \\
\text { and/or EEZ } \\
\text { - Chartering } \\
\text { agreements }\end{array}$ & $\begin{array}{l}\text { Addresses all matters related to fisheries management } \\
\text { and is normally divided into sub-parts. These include: } \\
\text { the formulation of fisheries management and } \\
\text { development policies and plans, content or elements } \\
\text { that need to be considered in the formulation of the } \\
\text { plans and the processes involved; the designation of } \\
\text { fisheries to be managed; the utilization, management } \\
\text { and development of fisheries or fisheries production } \\
\text { including the application for, consideration and granting } \\
\text { of concessions, lease, access agreements and entitlement } \\
\text { rights (e.g. licensing, fishing authorizations, permits, } \\
\text { registration), effort/input controls (e.g. limits on fishing } \\
\text { capacity with respect to fishing vessels and gears), fishing } \\
\text { gear and method controls (e.g. mesh size, prohibition on } \\
\text { destructive methods and use of toxic substances), spatial } \\
\text { and temporal controls (e.g. closed areas and closed } \\
\text { seasons), catch/output controls (e.g. total allowable } \\
\text { catch, bag limits). This part also deals with trade in } \\
\text { fish, fishery and aquaculture products, as well as with } \\
\text { conservation measures (e.g. protection of species, areas, } \\
\text { ecosystems, habitats and biodiversity, environmental } \\
\text { impact assessment/statement), restoration measures } \\
\text { and research. The provisions of this part give effect to } \\
\text { the implementation of international agreements the } \\
\text { country is a party to or to conservation and management } \\
\text { measures adopted by a RFMo or other regional } \\
\text { arrangement a country is a party to. Furthermore, this } \\
\text { part may also allow the country to enter into access } \\
\text { agreements with another country so that the latter can } \\
\text { fish in the former's territorial sea and/or EEZ. Provisions } \\
\text { on chartering agreements may be provided as well. }\end{array}$ \\
\hline
\end{tabular}




\begin{tabular}{|c|c|c|}
\hline \multicolumn{3}{|c|}{ Table (cont.) } \\
\hline Part & Main Components & Nature of Provisions \\
\hline $\begin{array}{l}\text { IV. } \\
\text { Monitoring } \\
\text { Control and } \\
\text { Surveillance }\end{array}$ & $\begin{array}{l}\text { - Observer programme } \\
\text { - Inspection scheme } \\
\text { - Reporting } \\
\text { - Catch documentation } \\
\text { scheme } \\
\text { - Controls on } \\
\text { transshipment and } \\
\text { landing } \\
\text { - Registration and } \\
\text { marking }\end{array}$ & $\begin{array}{l}\text { Provides for monitoring, control and surveillance (MCS) } \\
\text { measures, outlining e.g. the monitoring, compliance and } \\
\text { enforcement powers of authorized officers, observer } \\
\text { programmes and boarding and inspection schemes, } \\
\text { reporting of catch and effort data, VMS, recording and } \\
\text { marking of fishing vessels, and controls on landing and } \\
\text { transshipment. }\end{array}$ \\
\hline $\begin{array}{l}\text { V. } \\
\text { Enforcement }\end{array}$ & $\begin{array}{l}\text { - Offences } \\
\text { - Penalties } \\
\text { - Confiscation, } \\
\text { forfeiture or seizure } \\
\text { - Administrative and } \\
\text { judicial proceedings }\end{array}$ & $\begin{array}{l}\text { Provides for the description of prohibitions, violations } \\
\text { and offences, respective sanctions and penalties, seizure } \\
\text { of vessels, gears and catch, as well as the administrative } \\
\text { and judicial proceedings to follow which may be of } \\
\text { criminal, administrative and/or civil nature, and may } \\
\text { also include provisions on evidence and burden of proof } \\
\text { issues (if these are not found in other laws). }\end{array}$ \\
\hline $\begin{array}{l}\text { VI. } \\
\text { Regulations }\end{array}$ & - Miscellaneous matters & $\begin{array}{l}\text { Provides for the Minister or other relevant authority to } \\
\text { make regulations, or for the exercise of executive rule- } \\
\text { making powers in relation to technical and detailed } \\
\text { matters. The provision normally enables the Minister to } \\
\text { promulgate regulations or other subsidiary legislation } \\
\text { such as orders, by-laws etc. }\end{array}$ \\
\hline
\end{tabular}

\section{Preliminary considerations}

The analysis and options presented in this guide are focused on how fisheries legal instruments can, where appropriate, complement a party's CITES-implementing legal instruments in supporting the implementation of CITES in the fisheries sector. In addition, the guide also provides advice for those parties to CITES who already refer to relevant fisheries legislation as part of their practical implementation of CITES. First and foremost, this guide illustrates the importance of considering fisheries legislation and, where appropriate, fisheries policy, when considering how best to implement CITES.

The analysis and proposed options set out in this guide consider whether the elements of the CITES four minimum requirements (as set out in the NLP) can be reinforced in fisheries legal frameworks, and explore whether the typical elements of fisheries legislation can be strengthened with the aim of ensuring consistency, coherence, and complementarity between the principal legislation on CITES and the national fisheries legal and/or policy frameworks. The following four preliminary steps should be taken into consideration. 


\subsection{First step: verifying the status of the country in relation to CITES}

The first essential step is to identify which category within the NLP a particular party's legislation is currently placed (CITES, 2019c). Although this preliminary part of the guide is targeted at any party, it is important to know this information. For parties with legislation currently listed in either Category 2 or 3 , it would be useful to try to find out the nature of the specific gaps in the respective legislation and whether there are ongoing activities to try to address them. Consultation with the relevant CITES MA or the CITES Secretariat can assist.

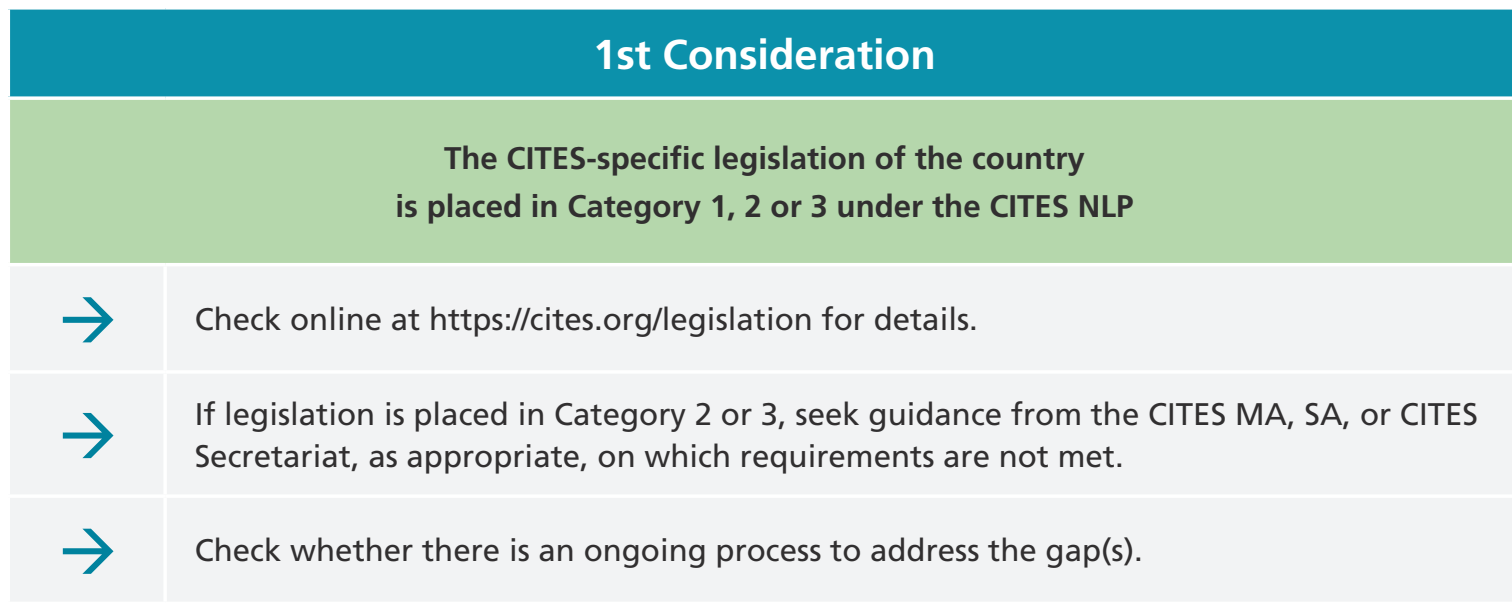

\subsection{Second step: identifying CITES-specific legislation and relevant fisheries legislation}

The next step is to identify the relevant legislation in place. As observed previously, the 102 parties currently categorized within NLP Category 1 have mainly CITES-specific legislation, some have other relevant subject-specific or sector-specific legislation, and only very few refer to fisheries legislation that also implements CITES. This does not mean that fisheries legislation does not address CITES-related issues to some extent, even if it does not specifically mention this. Indeed, most fisheries legislation (as well as aquaculture legislation) contain provisions on import and export of fish and fish products, including live fish (FAO, 2019b). As such, a careful review of fisheries legislation is necessary.

In this regard, it is important to look at the study that precedes this guide on implementing CITES through national fisheries legal framework. Annex D therein provides examples of CITESspecific legislation and CITES-related legislation currently placed in Category 1. Examples of fisheries legislation containing relevant provisions for CITES implementation are provided in Annex E. Both annexes are illustrative only and should not be viewed as adequate replacements for a proper review of relevant legislation that is carried out in-country, and where there is an opportunity to consult and obtain more information with government and other stakeholders.

While identification of CITES-specific legislation is relatively simple, the selection of fisheries legislation that is relevant for CITES implementation requires a more dedicated analysis. In general, the title of fisheries-related primary legislation will not have any reference to 
international trade or the protection of aquatic species. ${ }^{10}$ Consequently, it is important to thoroughly examine each legal instrument on a provision-by-provision basis, to check whether it contains specific rules on international trade activities as defined by CITES, namely: export, import, re-export or introduction from the sea. If the fisheries legislation addresses any of those matters, it can be regarded as relevant for CITES implementation or, as previously explained, it can be treated as CITES-related legislation. Even where the legislation does not expressly address the aforementioned matters, it may still be relevant for CITES implementation. Examples include: where such legislation establishes or designates authorities; regulates trade in fisheries products; protects certain aquatic species (with particular attention to CITES-listed species - see Annexes B.1 and B.2 of the study); provides a framework to combat IUU fishing or regulates other matters that may be relevant for CITES implementation in the fisheries sector.

2nd Consideration
$\begin{aligned} & \text { Identification of the main national } \\ & \text { CITES-specific legislation }\end{aligned}$
$\begin{aligned} & \text { e.g. Malaysia's International Trade in } \\ & \text { Endangered Species Act No. } 686 \text { of } 2008 .\end{aligned}$
$\begin{aligned} & \text { More examples in Annex D of the study. } \\ & \text { e.g. Samoa's Fisheries Management Act of } 2016 \\ & \text { fisheries legislation } \\ & \text { 2009. More examples in Annex E of the study. }\end{aligned}$
$\begin{aligned} & \text { Check online at http://www.fao.org/faolex/en/; https://www.ecolex.org and at any other } \\ & \text { website of national legislative bodies and authorities. }\end{aligned}$
$\begin{aligned} & \text { Check if legislation is in force and valid. } \\ & \text { Check both primary legislation (e.g. act, code, law, statute) and secondary legislation } \\ & \text { (e.g. decree, regulation, ministerial ordinance, order). }\end{aligned}$

\subsection{Third step: analysing key elements in the selected legislation}

After the relevant legal instruments within a particular country have been identified, then an analysis of each CITES-specific and CITES-related fisheries legal instrument should be undertaken to ensure, where appropriate, that it contains the relevant provisions for CITES implementation with regard to the aquatic species included in the CITES Appendices. When examining the CITES-specific legislation, it is important to note that the focus of this guide is not on improving CITES-specific legislation with respect to CITES itself. Rather, this guide takes into account the existing CITES-specific legislation with a focus on addressing the international trade in CITES-listed commercially exploited and managed aquatic species, but ultimately aims to enhance fisheries legislation for the implementation of CITES. As such, the analysis of legislation should be conducted with a view to incorporate elements that the CITES-specific legislation should have, including their contribution to the common high level objective of achieving responsible, legal, sustainable utilization of resources (species, biodiversity and ecosystems) - see Table 4 of the study.

\footnotetext{
${ }^{10}$ With respect to secondary or subsidiary fisheries legislation, however, a number of countries have enacted regulations addressing protected/endangered species of fish (e.g. Fisheries (Control of Endangered Species of Fish) Regulations 1999 in Malaysia) and also addressing the export of fish.
} 
This third step is crucial if the government considers amending existing CITES-specific legislation to better align it with existing relevant (CITES-related) fisheries legislation and vice versa. This effort is complementary to the expected amendments that would usually follow CITES implementation (e.g. in incorporating new or amended listings of species in accordance with the latest CoPs). In addition to altering the existing CITES-specific legislation to meet the new CITES requirements, it is important to ensure that both CITES-specific legislation and the fisheries legislation have appropriate provisions enabling cross-reference. Such provisions may be a cross-reference in one piece of legislation to the other and vice versa or relate to cooperation and coordination between the relevant authorities under different legislation.

The elements determined to be specifically relevant for CITES implementation in respect of aquatic species (hereafter referred to as "Key Fisheries Elements for CITES" and "Key CITES Elements for Fisheries") were identified and construed based on the study that precedes this guide, and on the discussions, analytical exercises and findings of the CITES Expert Workshop (FAO, 2019b). They reflect what, ideally, both CITES-specific legislation and CITES-related fisheries legislation provide, so that CITES implementation in respect of commercially exploited and managed aquatic species is adequately aligned with the fisheries sector. These elements help with examining the relevant instruments and in evaluating whether they contain provisions that are adequate in ensuring their application in a consistent, coherent and complementary manner. The following orientation highlights the seven Key Fisheries elements for CITES, which should be analysed in a country's existing CITES-specific legislation, and the six Key CITES elements for Fisheries that should be analysed in a country's existing fisheries legislation. It should be emphasized that these elements go beyond the CITES minimum requirements. They can be considered as recommendations/good practice but are not CITES requirements. 


\section{3rd Consideration}

The selected CITES-specific legislation:

1. provides for a clear definition of IFS in accordance with the interpretation given by the parties on Resolution Conf. 14.6 (Rev. CoP16), clarifying that the specific provisions on IFS apply to one-State transactions

2. provides for a clear definition of NDF and LAF in accordance with CITES, IFS Resolution Conf. 16.7 (Rev. CoP17) and Resolution Conf. 18.7 (Legal Acquisition Findings)

3. refers to compliance with, and applicability of, other relevant legislation (general terms) or fisheries legislation (specific terms)

4. designates the FA or other relevant authority responsible for fisheries management, conservation, development and MCS, maritime matters among the CITES SA and/or the MA

5. clearly outlines the mandates and responsibilities of the FA, the CITES SA and MA, ensuring coherence and includes the duty to cooperate and coordinate with other authorities

6. promotes or provides mechanisms for effective cooperation and coordination between those authorities as well as with other relevant authorities

7. protects all the CITES-listed species commercially exploited and managed, including the recent listing of sharks and rays

The selected fisheries legislation:

1. provides for a clear definition of international trade as comprising import, export, re-export and IFS transactions

2. refers to relevant definitions in CITES-specific legislation, particularly the meaning of MA, SA, IFS, NDF and LAF

3. makes cross-reference to compliance with, and applicability of, other relevant legislation (general terms), to CITES, or the relevant CITES-specific legislation (specific terms)

4. clearly outlines the mandates and responsibilities of: the FA; port authorities; other relevant authorities responsible for fisheries management, conservation, development and MCSE and maritime matters, ensuring coherence and includes the duty to cooperate or collaborate with other relevant authorities

5. promotes or provides mechanisms for effective cooperation, collaboration, coordination and interaction between the FA and other relevant authorities

6. protects and/or provides for conservation and management measures of CITES-listed aquatic species commercially-exploited and managed, including the recent listing of sharks and rays

Some useful examples of provisions found in current and draft ${ }^{11}$ CITES-specific legislation that could help in drafting CITES legislation with respect to each of the seven Fisheries Key elements for CITES are provided here. The examples of provisions found in current fisheries legislation are included in Section 6 on Legislative Options for implementing CITES through national fisheries legal frameworks.

\footnotetext{
${ }^{11}$ For instance, The Gambia's Draft International Trade in Wild Fauna and Flora Bill, 2018. Text of the draft bill was provided by the UNEP representative
} participating in the CITES Expert Workshop. 


\section{Key Fisheries Elements in CITES-specific Legislation}

1. Provides for a clear definition of IFS, in accordance with interpretation given by the parties on Resolution Conf. 14.6 (Rev. CoP16), clarifying that it consists of a one-state transaction

Saint Kitts and Nevis, International Trade in Wild Fauna and Flora Act No. 41 of 2009

Section 2. (...) "introduction from the sea" of a specimen means the transportation into the jurisdiction of Saint Christopher and Nevis of a specimen, which is taken from the marine environment, not under the jurisdiction of any State, including the air space above the sea and the sea-bed and subsoil beneath the sea".

2. Provides for a clear definition of NDF and LAF, in accordance with the Convention and IFS Resolution Conf. 16.7 (Rev. CoP17) and Resolution Conf. 18.7 (Legal Acquisition Findings)

Angola, Presidential Decree No. 311/18 approving the Regulation on the Import and Re-export of Wild Fauna and Flora Endangered Species of 2018

Article 4. (...) (tt) Non-harmful use: statement of CITES Scientific Authority, warning in a sense that a proposed import, export or introduction from the sea of specimens of LEA [List of Angolan Species of animal and plant species that occur in the national territory and that may be threatened by international trade] Categories and of Appendixes I or II of CITES is not harmful to the survival of the species.

The Gambia, Draft International Trade in Wild Fauna and Flora Bill of 2018

Section 2(1). In this Act, unless the context otherwise requires - (...) "legal acquisition finding" means a finding by the Management Authority of the State of export, which determines whether specimens were acquired by an applicant consistent with national laws; (...) "non-detriment finding" means a finding by the Scientific Authority advising that - (a) a proposed export of Appendix I or II specimens shall not be detrimental to the survival of the species, or (b) an introduction from the sea of Appendix I or II specimens shall not be detrimental to the survival of the species, and (c) a proposed import of an Appendix I specimen is not for purposes that would be detrimental to the survival of the species.

Lesotho, Zero draft International Trade in Endangered Species of Wild Fauna and Flora Bill of 2019

"Legal acquisition finding": A finding by the Director of the State of export determining whether specimens were acquired consistent with national laws. The applicant is responsible for providing sufficient information to show that the specimen was legally acquired.

"Non-detriment finding": A finding by the Scientific Authority advising that a proposed export or introduction from the sea of Appendix I or II specimens will not be detrimental to the survival of the species and that a proposed import of an Appendix I specimen is not for purposes that would be detrimental to the survival of the species;

3. Makes cross-reference to compliance with and applicability of other relevant legislation (general terms) or fisheries legislation (specific terms)

Fiji, Endangered and Protected Species Act No. 29 of 2002

Section 34. This act is in addition to the requirements under any other written law.

Jamaica, Endangered Species (Protection, Conservation and Regulation of Trade) Act No. 36 of 2000

Section 4(1). The provisions of this Act and any regulations made hereunder shall be in addition to, and not in derogation of, or in substitution for - (a) the Animals (Diseases and Importation) Act; (b) the Aquaculture, Inland and Marine Products and By-Products (Inspection, Licensing and Export) Act; (c) the Customs Act; (d) the Animal (Control of Experiments) Act; (e) the Fishing Industry Act; (...). 
4. Designates the FA or other relevant authority responsible for fisheries management, conservation, development and MCS, maritime matters among the CITES SA and/or the MA

Fiji, Endangered and Protected Species Act No. 29 of 2002

Section 4(1). This section establishes the Fiji Islands CITES Management Authority consisting of (...) (d) 3 public officers (the Ministry of Agriculture, the Ministry of Fisheries and Forests and the Fijian Affairs Board to nominate one each). (...) Section 7(1) This section establishes the Fiji Islands CITES Scientific Council consisting of (...) (b) the Director of Fisheries.

Chile, Law No. 20962 of 2016 applying CITES

Article 3. Pursuant to the present Law, the designated Management Authorities, in accordance with Article IV of the Convention, are the followings: (...) c) the National Service of Fisheries and Aquaculture, with respect to the hydrobiological species, d) the Directory of Environment and Maritime Issues of the Ministry of Foreign Affairs, which plays the coordinating role with the CITES Secretary and presides the National CITES Committee.

Solomon Islands, Wildlife Protection and Management (Amendment) Act No. 5 of 2017

Section 3D. The "CITES scientific authority" is: (...) (b) in relation to CITES species that fall within the definition of "fish" in section 2 of the Fisheries Management Act 2015 - the Ministry responsible for fisheries.

Bahamas, Wildlife Conservation and Trade Act of 2004 (Cap. 250A)

Section 2(1). In this Act - (...) "Scientific Authority" means the Department of Fisheries designated in accordance with Article IX of CITES.

5. Clearly outlines the mandates and responsibilities of the FA, the CITES SA and MA, ensuring coherence and includes the duty to cooperate and coordinate with other authorities

Bahamas, Wildlife Conservation and Trade Act of 2004

Section 6(2). The specific duties of the Management Authority shall include, but are not limited to, the following (a) to coordinate with other relevant authorities to implement and to enforce legislation of The Bahamas relating to speciesconservation;(b)tocommunicatewiththeCITESSecretariatandothermanagementauthorities; (...)Section8. It shall be the duty of all public authorities to cooperate fully with the Management Authority in enforcing this Act.

Malaysia, International Trade in Endangered Species Act No. 686 of 2008

Section 5. The functions of the Lead Management Authority shall be - (a) to coordinate the implementation and enforcement of the provisions of this Act by the Management Authorities and Scientific Authorities; (b) to communicate with all other countries and the secretariat of the Convention on all matters under this Act; (c) to cause national obligations under the Convention to be fulfilled; (d) to create awareness and to provide training, education and information relating to the Convention; (e) to do such other things as it deems fit to enable it to perform its functions effectively or which are incidental to the performance of its functions.

The Gambia, Draft International Trade in Wild Fauna and Flora Bill of 2018

Section 4(2). The Department of Forestry, the Department of Fisheries, and the Department of Customs and Excise (Gambia Revenue Authority) shall assist the Department of Parks and Wildlife Management in the performance of its functions as the CITES Management Authority for The Gambia. (...) Section 5(1) The Management Authority shall in particular - (...) (k) coordinate national implementation and enforcement of the Convention and this Act; (I) co-operate with other relevant authorities in the implementation and enforcement of the Convention and this Act. 
6. Promotes or provides mechanisms for effective cooperation and coordination between those authorities as well as with other relevant authorities

United States of America, Interagency cooperation - Endangered Species Act of 1973, as amended (50 CFR 402.01-402.48)

$\S 402.01$ Scope (...) (b) The U.S. Fish and Wildlife Service (FWS) and the National Marine Fisheries Service (NMFS) share responsibilities for administering the Act. The Lists of Endangered and Threatened Wildlife and Plants are found in 50 CFR 17.11 and 17.12 and the designated critical habitats are found in 50 CFR 17.95 and 17.96 and 50 CFR part 226. Endangered or threatened species under the jurisdiction of the NMFS are located in 50 CFR 222.23(a) and 227.4. If the subject species is cited in 50 CFR 222.23(a) or 227.4, the Federal agency shall contact the NMFS. For all other listed species, the Federal Agency shall contact the FWS. (...) $\$ 402.06$ Coordination with other environmental reviews. (a) Consultation, conference, and biological assessment procedures under section 7 may be consolidated with interagency cooperation procedures required by other statutes, such as the National Environmental Policy Act (NEPA) (42 U.S.C. 4321 et seq., implemented at 40 CFR parts 1500-1508) or the Fish and Wildlife Coordination Act (FWCA) (16 U.S.C. 661 et seq.). Satisfying the requirements of these other statutes, however, does not in itself relieve a Federal agency of its obligations to comply with the procedures set forth in this part or the substantive requirements of section 7. The Service will attempt to provide a coordinated review and analysis of all environmental requirements. (b) Where the consultation or conference has been consolidated with the interagency cooperation procedures required by other statutes such as NEPA or FWCA, the results should be included in the documents required by those statutes. (...) § 402.07 Designation of the lead agency. When a particular action involves more than one Federal agency, the consultation and conference responsibilities may be fulfilled through a lead agency. Factors relevant in determining an appropriate lead agency include the time sequence in which the agencies would become involved, the magnitude of their respective involvement, and their relative expertise with respect to the environmental effects of the action. The Director shall be notified of the designation in writing by the lead agency.

7. Protects all the CITES-listed species commercially exploited and managed, including the recent listing of sharks and rays

New Zealand, Trade in Endangered Species Order of 2017

Section 5(2). In Schedule 2, Part 1, of the [Trade in Endangered Species] Act [1989], replace the item relating Class - Elasmobranchii (sharks) (as replaced by clause 4 and amended by sub clause (1)) with [Silky Shark, Oceanic Whitetip Shark, Scalloped Hammerhead, Great Hammerhead, Smoot Hammerhead, Thresher Sharks, Basking Sharks, Great White Sharks, Porbeagles, Manta Rays and Devil Rays].

\subsection{Fourth step: ensuring coherence in selected legislation}

The evaluation of the aforementioned key elements in each identified legal instrument will demonstrate the status of a country's legal framework with respect to the provisions it offers for the implementation of CITES in its fisheries sector. In scrutinizing these preliminary considerations, the reviewer, legal drafter, practitioner or any other interested person using this guide should be able to identify potential gaps in the legislation, provisions which require amendment and how the legislation could be improved. The examples of selected provisions in both CITES-specific and fisheries legislation presented in the examples under the legislative options can also help the aforementioned persons to ensure consistency, coherence and complementarity in both categories of legislation. Any decisions and procedures that follow will depend on the country's legal system and political constraints, etc., but undertaking the recommended exercise means that the need to draft entirely new legislation is avoided, thus saving significant time and effort. 


\section{4th Consideration}

Seven Key CITES Elements and the extent to which any or all of them are reflected in the CITES-specific legislation are understood in order to inform legal drafters, practitioners, policy-makers and other relevant users of this guide on the approach or action that should follow
Six Key Fisheries Elements and the extent to which any or all of them are reflected in the fisheries legislation are understood in order to inform legal drafters, practitioners, policymakers and other relevant users of this guide on the approach or action that should follow

After undertaking this evaluation, and if a government decides to proceed in amending existing fisheries legislation or to enact new legislation, then the following detailed guidance for developing or enhancing fisheries legislation to implement CITES becomes relevant. 
Figure

Guide to implementing CITES through national fisheries legal frameworks

- 1st Consideration

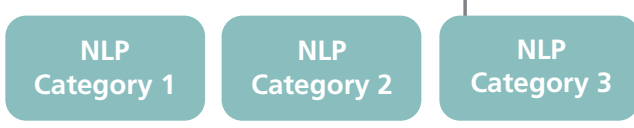

The Guide's

The Guide's

Preliminary Considerations

Draft Model Law Legislative Options

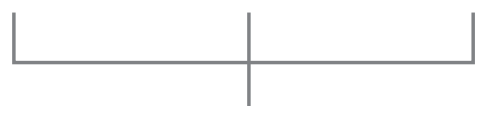

\section{2nd Consideration}

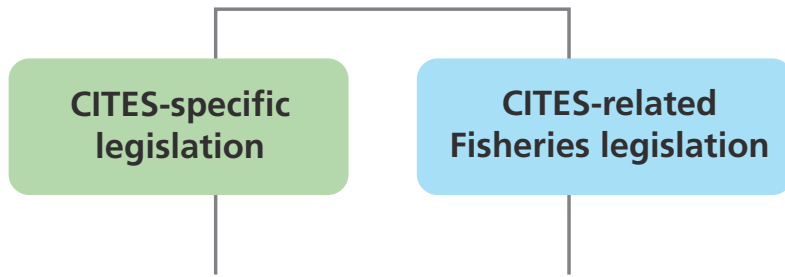

3rd Consideration

Analysis of seven Key Fisheries Elements for CITES

\section{4th Consideration}

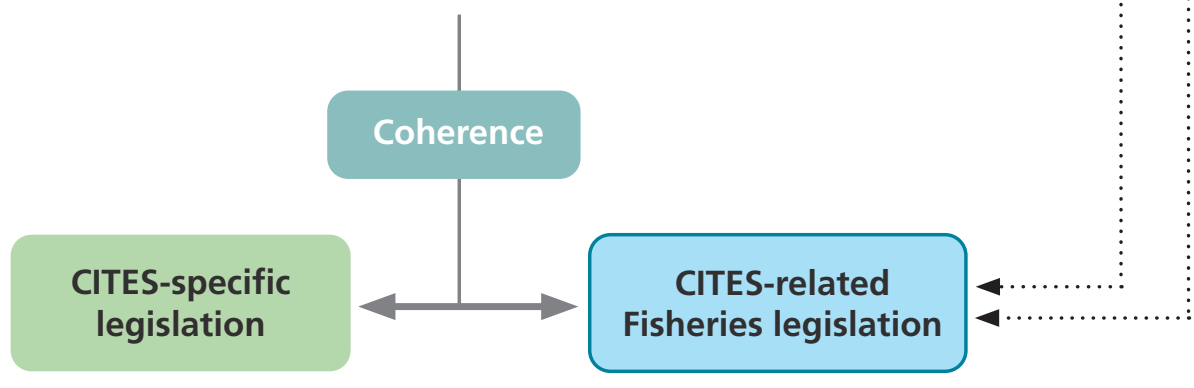




\section{Legislative options for implementing CITES through national fisheries legal frameworks}

This section sets out the legislative options for implementing CITES through national fisheries legal frameworks. It provides specific guidance on how the requirements of CITES, and related developments, including relevant non-legally-binding instruments, principles and approaches, can be reflected in such frameworks. It can also be used together with the CITES Model Law, for drafting provisions of CITES-specific legislation and it is therefore useful to any State, whether or not a party to CITES, or whether placed in any of the Categories 1, 2 or 3 within the NLP.

After having gone through the four preliminary considerations set out in Section 5 of this guide, the legal drafter, practitioner or other user of this guide will be able to decide on the need to either amend or completely replace the relevant fisheries legislation. They may use the following options to legislate for a particular matter within fisheries legislation as deemed appropriate. The approach and steps pursued herein follow the structure of the common primary fisheries enactments referred to in Section 4 of this guide. It is important to note that any cross-reference to CITES legislation made throughout these legislative options is based on the assumption that adequate CITES legislation is either already in place or is under development, at least in respect of the minimum requirements listed under the NLP.

The options presented in this section are the result of an analysis of current fisheries legal frameworks, both primary and secondary legislation of selected countries, to extract what is considered to be good practice. As emphasized in the study, the CITES regime and the fisheries sector interact to some extent, but adequate coordination and cooperation are often lacking in many instances, resulting in most fisheries legislation not providing an explicit reference to CITES and not providing for adequate coordination and cooperation. This section is conceived from the study, drawing from and building on the guidance material and tools for developing CITES-specific legislation. This includes, in particular, the CITES Model Law, as well as other guidance materials produced by FAO, especially the How-to Guide for an EAF. The legislative options also take into consideration the main findings of the CITES Expert Workshop (FAO, 2019b).

\subsection{Part I: Preliminary}

The relationship between the CITES regime and the fisheries sector needs to be appropriately addressed by the fisheries legislation so that the fisheries sector is made aware of CITES and its related requirements. To promote consistency, coherence and complementarity between the fisheries legislation and CITES legislation, or to at least ensure that the fisheries legislation is applied in accordance with CITES requirements, it is important that certain CITES-specific definitions or interpretations are cross-referenced or highlighted in the fisheries legislation. As suggested in Section 5 herein, special references to the definitions of CITES-listed species, MA, SA, international trade-related definitions including IFS, NDF and LAF should be provided by the fisheries legislation. Other relevant definitions related to the CITES regime issues and that have been identified in existing national fisheries legislation could be considered as well, such as "international conservation and management measure" and "regional fisheries management organization". 
Examples

\section{Definitions / Interpretations}

\section{Australia, Fisheries Management Act of 1991}

Section 4. (...) international conservation and management measure means a measure to conserve and manage one or more species of living marine resources that are adopted and applied, in accordance with the relevant rules of international law as reflected in the 1982 United Nations Convention on the Law of the Sea: (a) by a global, regional or sub regional fisheries organisation; or (b) by treaty or other international agreement. international fisheries management measure means a measure prescribed by the regulations to give effect to a measure established by an international fisheries management organisation. international fisheries management organisation means a global, regional or sub regional fisheries organisation or arrangement prescribed by the regulations.

\section{The Gambia, Fisheries Act No. 20 of 2007}

Section 2. "international conservation and management measures" means conservation and management measures established by international agreements which The Gambia has agreed to apply or to which The Gambia is a party".

Philippines, Republic Act No. 8550 of 1998 of the Fisheries Code, as amended in 2014

Section 4(17). Endangered Rare and/or Threatened Species - aquatic plants, animals, including some varieties of corals and seashells in danger of extinction as provided for in existing fishery laws, rules and regulations or in the Protected Areas and Wildlife Bureau of the Department of Environment and Natural Resources (DENR) and in the Convention on the International Trade of Endangered Species of Flora and Fauna (CITES).

Viet Nam, Law on Fisheries No. 18/2017/QH14 of 2017

Article 3(29). "regional fisheries management organization (RFMO)" means an organization which is responsible for regulating and taking measures for managing and preserving migratory fishes and aquatic species in international waters.

The provision(s) on the scope of application should reinforce the governments' commitment towards international legally-binding and non-legally-binding instruments that are relevant for CITES implementation, by stating that the legislation also gives effect to such instruments. The geographical scope of application of the legislation should be clarified taking into account three main elements. First, by expressly stating that the legislation applies to vessels flying the flag of the coastal State in waters under national jurisdiction, on the high seas or in waters under the jurisdiction of a third country, pursuant to the LOSC ${ }^{12}$ and, in the case of chartering, pursuant to a chartering agreement. Second, the legislation should expressly state that it applies to foreign fishing vessels engaged in fishing and fishing-related activities in the coastal States' maritime zones, pursuant to the applicable fishing agreement between the coastal State and the State whose flag the foreign fishing vessel is flying. Third, the legislation should expressly state that the legislation applies to species or specimens caught and landed anywhere by such vessels.

\footnotetext{
12 According to the LOSC, the coastal States have sovereignty over their territorial sea, and have sovereign rights for the purpose of, inter alia, fisheries in the EEZ See LOSC, Articles 2(1)(3) and 56(1)(a).
} 
Examples

\section{Scope / Application}

\section{Estonia, Fishing Act of 2015}

Chapter 1 - General Provisions. § 2. Scope of Application.

(...) (3) This Act regulates fishing in waters outside the jurisdiction of the Republic of Estonia by vessels for which Estonian papers of nationality have been issued or if the fishing is carried out in the case provided for in this Act by an operator registered in the commercial register of the Republic of Estonia in so far as the legislation of the country of location of the fishing ground or any international agreement regulating fishing in the fishing ground or the EU legislation does not provide otherwise.

\section{Guinea, Law No. 2015/26/AN of 14 September 2015 on the Maritime Fisheries Code}

Article 27. The present Code is interpreted and applied in conformity with the rules of international law, as reflected in the 1982 United Nations Convention on the Law of the Sea. The Code is also interpreted and applied in a compatible manner with the applicable provisions of the following legal instruments: (...) (d) the Convention on International Trade in Endangered Species of Wild Fauna and Flora (CITES).

Mozambique, Fishing Law No. 22 of 2013

Title I- General Provisions. Article 6. The Government shall, in specific: (4) Create the conditions, for the application of the relevant international conventions, in particular, the United Nations Convention on the Law of the Sea, the Convention on Biological Diversity and the International Convention for the Prevention of Pollution from Ships (MARPOL73/78).

\section{New Zealand, Fisheries Act No. 88 of 1996}

Section 5. This Act shall be interpreted, and all persons exercising or performing functions, duties or powers conferred or imposed by or under it shall act, in a manner consistent with - (a) New Zealand's international obligations relating to fishing; and (b) the provisions of the Treaty of Waitangi (Fisheries Claims) Settlement Act 1992.

In relation to the objectives/principles of legislation, it was observed in the study that there is a common general objective of sustainability shared by both CITES and the fisheries sector's communities. Fisheries legislation should therefore specifically include the objective to ensure, or to promote, responsible, sustainable and legal fisheries trade, taking due account of CITES-listed species. Most importantly, fisheries legislation should include the objective of ensuring consistency, coherence and complementarity between the fisheries legislation and other relevant legislation, such as any CITES-specific legislation applicable within the same jurisdiction. Other principles that should be outlined in this connection include the EAF, the application of the precautionary approach, stakeholder participation and transparency, and non-discrimination with respect to port inspection of foreign vessels. 
Examples

\section{Objective / Principle}

Kenya, Fisheries Management and Development Act No. 35 of 2016

Section 5(2). The implementation of this Act shall be guided by the following principles: (a) long-term sustainable use, conservation and management of fisheries resources and habitat and adoption and implementation of management measures in such a manner as to ensure that the fisheries resources and habitat are not overexploited, threatened or endangered.

Solomon Islands, Fisheries Management Act No. 2 of 2015

Section 2(1). In this Act, unless the context otherwise requires - (...) "Convention on International Trade in Endangered Species" means the Convention on International Trade In Endangered Species of Wild Fauna and Flora adopted in Washington on 3 March 1973". (...) Section 5(1) All functions, duties and responsibilities under this Act shall be exercised in a manner consistent with the following principles: (...) (i) international agreements and relevant international law shall be effectively implemented; (...) (q) conservation and management standards and measures in international agreements shall be applied to the extent possible.

\section{Thailand, Royal Ordinance on Fisheries, B.E. 2558 of 2015}

Section 4. The provisions of this Royal Ordinance aim to reorganize fisheries in Thailand and in waters at large with a view to preventing IUU fishing in order to preserve aquatic animal resources as a sustainable source of food for humanity and preserve the environment in an appropriate state along the line of approaches, criteria and standards recognized internationally, as well as to protect the welfare of seamen and prevent all forms of forced labour in the fisheries sector, with due regard to the following objectives: (...) (3) fulfillment of Thailand's international obligations with regard to the conservation and management of aquatic resources; (11) implementation of an effective traceability system from fishing operations to ultimate consumers.

These legislative options could be incorporated by countries in the form of provisions which:

a. cross-refer to CITES definitions, highlighting the definitions of CITES-listed species, MA, SA, international trade, including IFS, NDF and LAF;

b. in case these particular terms have not yet been defined, provide definitions in accordance with CITES and relevant Resolutions and, in relation to IFS, clarifying that it occurs when species or specimens are caught by a State's vessel in ABNJ (defining that term as well) and landed in its own port;

c. provide any other relevant definition or interpretation which may not be clearly defined or interpreted in the CITES legislation;

d. consider the State's general obligations under CITES;

e. recognize the complementarity between fisheries and CITES legislation, and apply the fisheries legislation in a manner that is consistent, coherent and complementary with CITES and/or CITES legislation;

f. include the objective of ensuring coordination and complementarity with any CITES legislation, especially cooperation and coordination between the relevant national authorities;

g. reinforce the legislation's role in creating the conditions for the implementation of CITES and any other relevant international instrument; 
h. clearly establish the application of the legislation to foreign fishing vessels engaged in fishing and fishing-related activities in the country's maritime zones, pursuant to the applicable fishing agreement;

i. clearly establish the application of the legislation to flag State vessel fishing in $A B N J$ in accordance with the international law and any applicable international conservation and management measures;

j. include the objective of ensuring responsible, sustainable and legal fisheries trade, with particular attention to CITES-listed species and specimens; and

k. outline any other relevant principles, including the EAF, stakeholder participation, transparency, and non-discrimination.

\subsection{Part II: Administration}

The designation of the CITES MA and SA is provided by the CITES legislation. In relation to CITES-listed commercially exploited and managed aquatic species, it is important that the FA is designated as a CITES SA. Such designation would not be expected in fisheries legislation, but fisheries legislation should ensure that it contains provisions for institutional arrangements and mechanisms that promote effective cooperation and coordination between the CITES and fisheries regimes. These provisions and mechanisms should not only stipulate the respective role of the relevant FA, MA and SA, but also mention any other relevant authorities playing important roles in CITES implementation, such as those engaged in port and at-sea inspection, customs, port and maritime enforcement agencies. To ensure and facilitate this cooperation and coordination, the head of the FA should be empowered to delegate duties to other relevant institutions for the better discharge of the FA's functions. This provision decentralizes the ability to make relevant decisions and to take action on any relevant matter as delegated by the FA. The FA could then allow other relevant authorities (e.g. customs and enforcement authorities) to support it in matters related to CITES implementation.

Examples

Institutional Arrangements ${ }^{13}$

Angola, Aquatic Biological Resources Law No. 6-A/04 of 2004, as amended in 2005

Article 217. (1) It is the responsibility of the competent Ministry to coordinate the execution of all activities of fisheries monitoring and surveillance, as well as of hygiene-sanitary control of processing facilities and sale of fish and fishery products, in which there is intervention of services from the local and central state administration, nondependent of the competent Ministry and the coastal and riverside communities. (2) The powers referred in the previous provision can be delegated to autonomous bodies under the authority of the competent Ministry.

Ghana, Fisheries Act No. 625 of 2002

Part I - Fisheries Commission. Section 20. Delegation by Director. The Director may delegate any function to a Deputy Director or any other officer of the Commission subject to any condition that the Director may impose but the Director shall not be relieved from ultimate responsibility for the discharge of the delegated function.

13 See more examples in FAO, 2016, Component 4. 
Mexico, Fisheries Regulations of 1999

Article 14. The trade of live, fresh, frozen fishery products from fishing or aquaculture, between the federal entities with a marine coast and those landlocked federal entities must be supported by the Guide for Fishery issued by the Secretary of the Environment, Natural Resources and Fisheries.

Article 14bis-3. (III) Whether the interested parties do not meet the requirements of information and documentation, the Guide for Fishery will not be signed and sealed, and at that time, the fishing authority will verbally notify the interested party to address the missing documentation. The interested party will then start a new procedure to fulfil the required information and documentation. In dealing with CITES species, the Secretary will give the corresponding intervention to the Secretary of the Environment and Natural Resources, which will act in accordance with the applicable legal provisions.

Philippines, Republic Act No. 10654 of 2014, amending the Fisheries Code Republic Act No. 8550

Section 16. Section 65 of the same Act is hereby amended, as follows: "Section 65. Functions of the Bureau of Fisheries and Aquatic Resources. - As a line bureau, the BFAR shall have the following functions: (...) (r) formulate and implement rules and regulations for the conservation and management of straddling fish stocks, highly migratory fish stocks and threatened living marine resources such as sharks, rays and [Dugong], inter alia, in the Philippine Exclusive Economic Zone, territorial sea, archipelagic and internal waters, in coordination with LGUs [Local Government Units] and integrated/municipal/city Fisheries and Aquatic Resources Management Councils";

Stakeholder participation with respect to CITES policy matters (e.g. production of data and stocks assessment of CITES-listed aquatic species) should include all relevant stakeholders in the context of an EAF, including lower-level authorities and the small-scale fisheries sector's representatives. The How-to Guide for an EAF addresses institutional arrangements, mechanisms for stakeholder participation and transparency, and arrangements for cooperation and coordination between the FA and other relevant institutions (Components 4, 5 and 6). Mechanisms for stakeholder participation in the CITES context could take the form of a provision in the fisheries legislation for advisory bodies composed of a wide range of different stakeholders. These could include academia; the fishing industry and the small-scale fisheries sector. This provides an opportunity for all actors to share information on CITES, to improve their knowledge of CITES and to contribute to its implementation. The fisheries legislation should also require the convening of well-publicized public consultations and meetings, conducted in a timely manner, so that any interested stakeholders could actively participate in discussing CITES-related matters.

Given that there may be cases where CITES-listed species (e.g. Hammerhead sharks) are harvested by small-scale fisheries and may enter international trade or impact the preparation of the respective NDFs, small-scale fisheries representatives should be offered the opportunity to participate and have their opinions appropriately documented, registered and taken into account in any discussions concerning CITES and the listing of species in its Appendices. The legislation should promote public awareness of CITES legislation, the significance of protecting particular species, as well as the importance of the participation of fishers engaged in any fishing or fishing-related activity in the identification of CITES-listed aquatic species, so that all relevant persons know which species are subject to CITES requirements. 
Examples

\section{Stakeholder Participation ${ }^{14}$}

\section{Angola, Aquatic Biological Resources Law No. 6-A/04 of 2004, as amended in 2005}

Article 65. In addition to other provisions under this law, the following measures are considered measures of protection of aquatic biological resources and ecosystems: (...) (j) the adoption of procedures that ensure the participation of the interested persons, including non-governmental organizations, fisheries enterprises and coastal and riverside communities.

Article 67. (1) In addition to other provisions under this law, the competent Ministry must, namely: (...) ensure the participation of the persons interested in the preservation of aquatic biological resources, especially fishers, fisheries professional organizations, coastal and riverside communities and environmental protection organizations.

Mozambique, Decree No. 43 of 2003 on Marine Fisheries' Regulation (REPMAR)

Article 15 Co-management Model (1) The Ministry of Fisheries shall adopt the co-management model as the preferential model to ensure fisheries management. (2) The co-management model consists of a system that has the main following objectives: (a) guarantee responsible management of fisheries; (b) ensure the right of access to fisheries of fishing communities, taking into account the protection and promotion of their wellbeing; (c) fostering the participation of fishing communities in the planning and application of fisheries management plans; (d) fostering the capacity-building; (e) creating a favourable environment to the coexistence of artisanal fishers, semi-industrial and industrial ship-owners. (3) The Fisheries Management Commission and the Co-Management Committee are the fora of the co-management model where all the interested groups are represented. Article 16 Fisheries Management Commission. (1) The Fisheries Management Commission (CAP) is a consultative body of the Fisheries Administration to pronounce on matters of interest and concerning the preservation of fishery resources and fisheries management, namely: (a) development plans, (b) total allowable catch, fisheries quotas and their establishment, (c) maximum number of licensed fishing vessels per fishery; (d) closing seasons; (e) other fisheries management measures or of marine aquatic environment preservation. (...) Article 17(3) Members of the CAP are mandatory: (a) National Directors responsible for the administration and management of fisheries, (b) representatives of the National Institutes administered by the Fisheries Ministry, (c) representatives of the industrial fishing associations; (d) representatives of the semi-industrial fishing associations and (e) representatives of the artisanal fishing organizations.

Where the fisheries legislation provides for the conditions of access by foreign vessels for fishing in the country's territorial sea and/or EEZ, or where the fisheries legislation addresses chartering agreements, it is important that the legislation makes reference to the CITES requirements if the foreign fishing vessel and the chartered vessel catch any CITES-listed species in the coastal State's territorial sea and/or EEZ, and lands it in the authorized port, as agreed. The fisheries legislation may address this issue in very general terms, requiring the relevant agreement to be subject to conditions established under international law, which covers CITES as well. 
Examples

\section{Access Agreements}

\section{Jamaica, Fisheries Act No. 18 of 2018}

Section 49. Access agreements and arrangements. (...) (3) An access agreement or arrangement entered into under subsection (1) shall include provisions - (a) establishing the responsibility of the states, intergovernmental organizations or associations representing foreign fishing vessel owners or charterers to take all necessary measures to ensure compliance by its fishing vessels with - (i) the access agreement or arrangement; (ii) this Act, any Regulations made under this Act or any other enactment relating to fishing and any related activity; and (iii) any international fisheries conservation and management measures; (b) granting the Minister the right, after consultation with the Authority and the Minister responsible for foreign affairs, to terminate the agreement or arrangement in the case of non-compliance by the other party to the access agreement or arrangement with any requirement of the agreement or arrangement or the provisions of this Act or any Regulations made under this Act or any other relevant enactment; and (c) granting the Minister the right, after consultation with the Authority and the Minister responsible for foreign affairs, to suspend the agreement or arrangement on the determination of the Minister that continued fishing at current levels would threaten the fish stocks.

Tonga, Fisheries Management Act No. 26 of 2002

Section 37. Terms and conditions of access agreements. (1) Any access agreement or arrangement referred to in this section shall include a provision, in relation to a State, that such State shall assume flag state responsibility, and otherwise establish the responsibility of the foreign party or parties to ensure compliance by its vessels with the terms and conditions of the agreement, international conservation and management measures, international law and with the laws relating to fishing in the fisheries waters.

These legislative options could be incorporated in the fisheries legislation through provisions which:

a. clearly delineate the mandate of the FA, including the duty to cooperate and coordinate with any relevant authority (in general terms) or with designated CITES MAs and SAs (in specific terms);

b. allow for the delegation of power from the FA to other relevant authorities to ensure effective cooperation and coordination, taking into account that such delegation does not relieve the MA or SA from their own duties as provided in the CITES legislation;

c. promote stakeholder's participation, including that of small-scale fishers, in discussions and consultations on the possible listing of aquatic species in the CITES Appendices;

d. establish an advisory council comprising a range of stakeholders from different societal sectors and levels of authority to share information about CITES implementation;

e. outline proceedings for public meetings or hearings related to CITES, ensuring timely notification of the public and active participation of interested stakeholders;

f. promote awareness of CITES legislation, requirements for international trade in CITES-listed aquatic species and 
g. include, within the minimum conditions of access agreements and chartering agreements, the requirement of compliance with international obligations and CITES.

\subsection{Part III: Management}

The substantive provisions on access to fishing, planning, sustainable use, management and development of fisheries can address the various CITES requirements. This contributes to strengthening the management, trade and conservation of CITES-listed species. Many recent fisheries enactments already provide for relevant objectives and principles of management, following an EAF. In particular, attention should be given to fulfilling conservation and management obligations or commitments under international and regional legally-binding and non-legally-binding instruments, including CITES and RFB conservation and management measures. Other relevant principles include the sustainable use of marine living resources, the need to protect marine biodiversity and the need to minimize marine pollution.

Examples

\section{Management Objectives / Principles}

\section{The Gambia, Fisheries Act No. 20 of 2007}

Part IV. Fisheries Conservation, Management and Development. Section 9. In the exercise of any powers and functions under this Act, consideration and priority shall be given to the following principles - (h) collecting and sharing in a timely manner and in accordance with fisheries management agreements and international law, complete and accurate data concerning fisheries and aquaculture as well as information from national and international research programmes; $(n)$ ensuring that any conservation and management measures allow for the implementation of relevant international agreements to which The Gambia is a party or has consented to be bound.

\section{South Africa, Marine Living Resources Act No. 18 of 1998}

Section 2. The Minister and any organ of state shall in exercising any power under this Act, 25 have regard tothe following objectives and principles: (a) The need to achieve optimum utilisation and ecologically sustainable development of marine living resources; (b) the need to conserve marine living resources for both present and future generations; (c) the need to apply precautionary approaches in respect of the management and development of marine living resources; (d) the need to utilise marine living resources to achieve economic growth, human resource development, capacity building within fisheries and Mariculture branches, employment creation and a sound ecological balance consistent with the development objectives of the national government; (e) the need to protect the ecosystem as a whole, including species which are not targeted for exploitation; ( $f$ ) the need to preserve marine biodiversity; (g) the need to minimise marine pollution; (h) the need to achieve to the extent practicable a broad and accountable participation in the decision-making processes provided for in this Act; (i) any relevant obligation of the national government or the Republic in terms of any international agreement or applicable rule of international law.

Catch/output controls are usually established by the FA based on catch data and scientific research. The fisheries legislation should provide that stock assessments carried out for the establishment of such limits are made available to CITES authorities when the species is a CITES-listed species. Information-sharing on such data should also be guaranteed among FAs and relevant RFBs for transboundary stocks, with special attention paid to CITES-listed species. Other controls include restrictions on catch of certain species as well as spatial and temporal controls. 
Examples

\section{Moratoria, Prohibitions and Other Controls}

Cabo Verde, Legislative Decree No. 02 of 2020 approving the general regime regulating fishing activities in national maritime waters and the high seas

Article 84. (1) It is prohibited, in all national territory and at any time, to kill, mutilate, capture, remove or hunt marine species threatened with extinction and protected by the present law, special legislation and other national legislation, as well as those species listed in Appendix I of the CITES. (2) The marine protected and threatened species include, namely, and for the purposes of the present law, the marine mammals, all species of turtles and certain species of sharks, pursuant to regulation. (3) In the event of non-targeted marine protected or endangered species, these must be released and recorded in the fishing logbook. (4) It is prohibited the transport, trade, use, offer for sale or buying any marine protected and endangered species according to the present law, as well as its derivative products.

Fiji, Fisheries (Amendment) Regulations L.N. No. 78 of 2004

Section 2. The Fisheries Regulations is amended by inserting after regulation 20A, the following regulation"Moratorium on the Humphead Wrasse" 20B - (1) No person shall - (a) Take or capture for sale or offer for sale by any means any Humphead wrasse; (b) export, sell or offer for sale, or possess live specimens of any Humphead wrasse for any commercial purpose; (c) export, sell or offer for sale, or possess any parts of Humphead wrasse for the purpose of trading or for income generation

Honduras, Accord No. 22 of 2019

Paragraph 9. The closure of fishing of all species of sharks in waters under the jurisdiction of the Republic of Honduras is continued, with the full prohibition on catching, keeping, national trade and export of all parts of sharks species and its derivatives (fins, meat, skin, oil, mandibles, etc); except only and exclusively in the cases of incidental catch of sharks with trammels, as duly proved by DIGIPESCA, according to the Legislative Decree No. 26-2016, published in the Official Gazette on 23 May 2016. It is also prohibited the import of any species of sharks regardless of its county of origin.

Honduras, Accord No. 735 of 2008

First. Maintain the indefinite moratorium established by the government of Honduras upon request of the CITES Secretary since September 2003. Second. Continue with the indefinite prohibition of Queen Conch (Strombus gigas) and reaffirms the measures for compliance with such prohibition.

Peru, Ministerial Resolution No. 306 of 2004

Article 1. Prohibit the capture of Seahorse resource or Hippocampus in marine waters under the Peruvian jurisdiction, from the day following the publication date of the present Ministerial Resolution, until the relevant studies determine that such resource may be explored without risk to its survival.

Philippines, Republic Act No. 8550 of 1998 of the Fisheries Code, as amended in 2014

Section 11. Protection of Rare, Threatened and Endangered Species. - The Department shall declare closed seasons and take conservation and rehabilitation measures for rare, threatened and endangered species, as it may determine, and shall ban the fishing and/or taking of rare, threatened and/or endangered species, including their eggs/offspring as identified by existing laws in concurrence with concerned government agencies.

Licences of national and foreign fishing vessels for the relevant areas within national jurisdiction should include provisions on disqualification of applications, denial of the same, cancellation of a fishing licence in certain circumstances. Grounds for denying the grant of, or for the revocation of, a licence to fish within waters under national jurisdiction should include any violation by the applicant or licence holder of any CITES requirements for trade in species listed in Appendix I. The same provision should apply to national vessels operating on the high seas 
under the authority of an authorization from the flag State. There should be provisions for the suspension of issued licenses if the violation has occurred with respect to species listed in Appendices II or III. The legislation should also provide for the right of any aggrieved persons to appeal against those decisions. Licence conditions should include the obligation to report any CITES-listed species caught and landed as well as the location of such catches (to facilitate identification of IFS scenarios) to the FA and the MA. There should be provisions requiring entries to be made in the fishing logbooks, including where specimens are released (as bycatch or discard). To facilitate reporting, the fishing logbook should contain a field or box in the logbook template dedicated to CITES-listed species and related information.

Examples

\section{Catch reporting / Licensing}

Samoa, Marine Wildlife Protection Regulations S.R. 2009/18 of 2009

Section 4. Reporting incidents involving marine mammals-(1) Any person who accidentally captures, injures or kills a marine mammal whilst undertaking any fishing activity in Samoan waters shall report the incident as soon as practicable to: (a) the Division of Environment; and (b) the Fisheries Division. (2) A person who is required to report an incident under sub-regulation (1) shall provide such information and verification of the matters reported as is required by the Division of Environment and the Fisheries Division. (...) Section 19. General procedures applying to permits and licences- (...) (3) The Minister may: (a) refuse an application on any ground associated with the protection and conservation of marine wildlife (...)

Provisions on trade in fisheries and aquaculture products can be found in fisheries legislation. These usually prohibit export or import without the relevant authorization from the competent authority (e.g. FA). These provisions do not usually include IFS. Consequently, the fisheries legislation should appropriately highlight the occurrence of such trade transactions and the applicability of CITES legislation to this and other trade activities in respect of CITES-listed species. There should be specific conditions in relation to the CITES transactions (import, export, re-export and IFS) in any authorization, permit, certificate or licence. There should be an express requirement for the establishment of export quotas for Appendix II-listed species and, where applicable, Appendix-III listed species. The fisheries legislation could additionally if deemed necessary, provide even stricter requirements, such as a complete ban on trade in certain CITES-listed species.

Examples

Trade in fisheries and aquaculture products

Cambodia, Royal Kram NS/RKMI0506/011 on Promulgation of the Fisheries Law of 2006

Article 68. Exporting, importing, buying, selling, transporting, processing and stocking of endangered fishery products shall only be authorized for products from aquaculture and/or in compliance with Articles 64, 65, 66 and 67 of the law on fisheries and CITES Convention. The endangered fishery products shall be determined by a sub-decree.

Ecuador, Accord No. 204 of 2016

Article 2. In the case of import or export of living animals, meat or sub-products of Arapaima gigas (pirarucu); this shall be conducted in conformity with the regulation established in the CITES and other norms in force. 
Kenya, Fisheries Management and Development Act No. 35 of 2016

Part VI - Import, Export and Trade and Marketing of Fish and Fish Products. Section 54. Import and release of live fish (1) No person shall import any live fish into Kenya without the written approval of the DirectorGeneral and in accordance with such procedures as may be prescribed and the approval shall only be given upon production of an environmental impact assessment report on the effect of each introduction. Section 55. Export of live fish (1) No person shall export any live fish from Kenya except in accordance with regulations.

Mali, Fisheries and Aquaculture Management Law No. 2014-062 of 2014

Article 48. The export, re-export, import, and transport and transit of fish specimens included in the appendices of the CITES and all the specimen of local fish species are regulated by the provisions of the mentioned convention and implementing instruments.

Mexico, Fisheries Regulations of 1999, as amended in 2004

Article 14. The trade of live, fresh, frozen fishery products from fishing or aquaculture, between the federal entities with a marine coast and those landlocked federal entities must be supported by the Guide for Fishery issued by the Secretary of the Environment, Natural Resources and Fisheries.

Article 14bis-2. The Secretary will publish in the Official Diary of the Federation the format of the Fishing Guide which must contain: (...) X - (...) date and customs of import's application, in the case of species caught outside national waters and number and date of the CITES certificate whether the products come from endangered species of wild aquatic fauna and flora.

Article 14bis-3. The procedure for the issuance of the Guide for Fishery is subject to the following: (I) the interested parties may obtain the format of the Guide for Fishery on the internet website of the Secretary and the National Commission of Aquaculture and Fisheries, or in any other fisheries offices of the Secretary, where the relevant data can be found (...) The format will also need to contain documentation about the legal origin of the fishery products to be transported and, where appropriate, the inventory of prohibited or restricted species, or customs import application, in the case of species caught outside Mexican waters, and/or CITES certificate whether the products come from endangered species of wild aquatic fauna and flora. (...) (III) Whether the interested parties do not meet the requirements of information and documentation, the Guide for Fishery will not be signed and sealed, and at that time, the fishing authority will verbally notify the interested party to address the missing documentation. The interested party will then start a new procedure to fulfil the required information and documentation. In dealing with CITES species, the Secretary will give the corresponding intervention to the Secretary of the Environment and Natural Resources, which will act in accordance with the applicable legal provisions.

Solomon Islands, Fisheries Management Act No. 2 of 2015

Section 59(5). The Director shall not issue a licence for the import or export of live fish unless all requirements of the Convention on International Trade in Endangered Species of Wild Fauna and Flora are fully met in relation to the import or export.

The country's fisheries management plan (FMP) should prohibit the possession and retention of any CITES-listed species by vessels flying its flag. In respect of live species, the prompt release of such species unharmed should be expressly required. Research on CITES-listed species should be encouraged within national research programmes, and institutions should exchange information on their findings and make such information available to the public. The national list of CITES-listed species should be reviewed periodically, at least after the most recent CoP. Frequently, fisheries enactments provide conservation measures for certain CITES-listed species through the establishment of a marine protected area or sanctuary, in which it is prohibited to catch these species, or through methods similar to RFB conservation and management measures for sharks. Awareness-raising should be promoted, and the fisheries legislation should provide that all fishing licences be accompanied by a list of CITES-listed aquatic species (with reference to the common name of the species and specimens as well as pictures of such species). 


\section{Conservation}

\section{Costa Rica, Decree No. 41 056-MINAW of 2018 on Golfo Dulce Natural Sanctuary of Hammerhead Shark}

Article 2. The fishing, capture, exploitation, transport and trade of hammerhead sharks inside the Golfo Dulce Sanctuary of Hammerhead Sharks is prohibited.

Cook Islands, Marine Resources (Shark Conservation) Regulations of 2012

Section 5(1). No person may: (a) catch, capture, target or otherwise intentionally engage in fishing (as that term is defined in Section 2 of the Act) for any shark; (b) remove the fins of, or otherwise mutilate or injure, any shark; or (c) chum for, or otherwise add substances to the water to attract, any shark. (2) If any shark is caught or captured, it must be immediately released, whether dead or alive, it must be released in the manner that affords it the greater opportunity for survival. No shark, or any part of a shark, may be retained even if caught as bycatch. (3) No person may possess, receive, transfer, store, have on board, or transship any shark, or any part of a shark. For purposes of this subsection, there is a presumption that, if any shark or any part of a shark is found aboard a vessel, the shark or shark part was possessed or transferred in violation of this subsection. (4) No person may possess, sale, offer for sale, take, purchase, barter, transport, export, import, trade or distribute shark, shark fins or any part of a shark in the Cook Islands.

Philippines, Fisheries Administrative Order No. 185 of 1992

Section 2. Prohibition - It shall be unlawful to take or catch dolphins in Philippine waters or to sell, purchase, possess, transport, or export the same whether dead or alive, in any state or form whether raw or processed: Provided, That the Secretary of Agriculture, upon the recommendation of the Director of Fisheries and Aquatic Resources, may issue a special permit in favour of any government or private agency or institution engaged in research work on dolphins, including those to be used for exhibition or show purposes subject to such terms and conditions as the said Secretary may deem wise to impose.

It shall, likewise, be unlawful to wound or kill dolphins in the course of catching other species of fish. Dolphins, which are accidentally included in the catch by any gear shall immediately be released unharmed in the sea; otherwise, the liability shall be deemed to still exist. Dead dolphins that are washed to the seashore shall be surrendered to the nearest Department of Agriculture Office for Proper disposition.

These legislative options could be incorporated in the fisheries legislation through provisions which:

a. ensure fisheries management and trade are conducted in accordance with international and regional legally-binding and non-legally-binding instruments, including CITES, CITES regulations, and RFBs' conservation and management measures;

b. communicate stock assessments and other data concerning CITES-listed species to the CITES authorities and relevant RFBs;

c. deny or cancel an application for a fishing licence by a national or foreign fishing vessel, if proved that the applicant has engaged in IUU fishing or has violated CITES requirements for commercial trade in Appendix I listed species;

d. include within the fishing licence conditions the duty to report to the FA and the CITES MA any catch of any CITES-listed species, including bycatch, and the location where the said species was caught; 
e. make cross-reference between CITES legislation in the provisions on trade in fisheries and aquaculture products, highlighting the occurrence of all trade transactions, including IFS and re-export;

f. ensure the FMP prohibits the commercial trade in species listed in CITES Appendix I and, with respect to live species listed in CITES Appendix I, that CITES requires their prompt and unharmed release, to the extent possible;

g. require any fishing licence to be accompanied by a list with the common names of CITES-listed aquatic species;

h. may impose a moratorium or prohibition on the capture, whenever possible, and commercial trade of CITES species listed in Appendix l;

i. establish marine protected areas, in consultation with all relevant stakeholders, in which capture and commercial trade of CITES species listed in Appendix I are prohibited; and

j. promote research on CITES-listed species and information-sharing between research institutions, FA, CITES authorities and RFBs.

\subsection{Part IV: Monitoring, Control and Surveillance}

Fisheries legislation also generally dedicates a substantive part to MCS provisions, setting out the powers and functions of authorized officers, as well as activities, mechanisms and tools that are relevant for ensuring fishing and fishing-related activities are carried out legally and sustainably. The How-to Guide for an EAF contains guidance on how these MCS aspects, including enforcement measures, should be included in fisheries legislation (Component 11), (FAO, 2016). These provisions should establish observer programmes for the collection, recording, and reporting of information, and statistical data relating to any fishing and fishing-related activity that may be relevant to CITES and may include explicit reference to CITES requirements. There should be effective communication between observers and the FA, CITES authorities, RFBs and any other relevant authorities to ensure that the data becomes available, shared and exchanged. 
Examples

\section{Observer Programme}

\section{Jamaica, Fisheries Act No. 18 of 2018}

Section 79. Observers. (1) The Authority shall plan and manage an observer programme for the purposes of collecting and reporting reliable and accurate information for scientific, management and compliance purposes. (2) Pursuant to subsection (1), the Authority may, in writing, designate a person to be an observer, for the purposes of the observer programme, on a fishing vessel, at an aquaculture facility or any other facility related to fisheries or aquaculture that has been granted a licence, authorization or permit under this Act. (3) An observer shall on request, identify himself and produce evidence that he is an observer, and the production by an observer, of any identification document issued to him, shall, until the contrary is proved, be sufficient authority for the observer to do anything which he is authorized to do under this Act. (4) An observer may exercise scientific and monitoring functions and such other functions as the Authority may determine.

\section{Saint Kitts and Nevis, Fisheries Aquaculture and Marine Resources Act No. 1 of 2016}

Section 91. Observer program. (1) The Director may establish an observer program, including for purposes of cooperation with an observer program established under a fisheries management agreement or by a relevant regional fisheries management organizations for the purpose of collecting, recording and reporting reliable and accurate information for scientific, conservation, management and compliance purposes including - (a) the species, quantity, size, age and condition of fish taken; (b) the methods by which, the areas in which, and the depths at which, fish are taken; (c) the effects of fishing methods on fish and the environment; (d) all aspects of the operation of any vessel; (e) processing, transportation, transshipment, storage or disposal of any fish or fish products; ( $f$ ) monitoring the implementation of management measures and applicable international conservation and management measures; and ( $g$ ) any other matter that may assist the Director to obtain, analyse or verify information for fisheries scientific, conservation, management and compliance purposes.

Provisions that empower the FA to establish and implement inspection schemes should also be extended to provide coverage of CITES requirements, including the setting out of any enforcement powers available to the authorized officer (Section 30, Model Law), and the PSMA provisions concerning port inspection (Articles 12-15 and Annex B of the PSMA). As such, it is important to ensure that the provisions are in alignment and do not conflict. It would be more appropriate that the fisheries legislation maintains its usual provisions on inspection and emphasize the duty of the inspector and any other relevant authorized officer to cooperate and coordinate with CITES enforcement authorities (e.g. customs, police). In particular, the fisheries legislation may highlight the powers of the authorized officer to board, search and inspect vessels and, where appropriate, seize documents relevant to CITES, especially the certificates, permits or any other relevant documents that may contribute to proving the legality of the fishing activity, including provisions on CDS. These provisions can also be outlined in broad terms so that the inspector can examine any type of documents including documents and records in electronic format, which would cover CITES relevant documents. ${ }^{15}$ 
Examples

Inspection Scheme

Fiji, Offshore Fisheries Management Decree No. 78 of 2012

Section 48. (1) For the purpose of the enforcement of this Decree, if an authorized officer believes on reasonable grounds that a person - this Decree and that - (a) is or has been engaged in the taking or selling of fish; (b) has purchased, is or has been in possession of fish; or (c) is committing or has committed an offence against this Decree, the authorized officer may, at any reasonable time question that person or any other person, and - (i) require the person being questioned to provide an answer, including any explanation or information concerning any vessel, or any place or thing, or any fish or fishing method, gear, apparatus, record, document, article, device, or thing relating to the taking, sale, purchase, or possession of any fish; and (ii) require that person or any other person to produce any permit, authority, approval, permission, licence, or certificate issued in respect of any vessel or person.

Tonga, Fisheries Management Act No. 26 of 2002

Section 71. Powers of authorized officers. (1) Any authorized officer, without a warrant - (...) (g) within the fisheries limits stop, enter and search any vessel, vehicle or aircraft which, on reasonable grounds, he suspects is transporting fish or fish products or is being or has been used or involved in the commission of an offence against this Act or its regulations; (...) (j) at all reasonable times enter and inspect any fish processing establishment for which a licence is held or required or any other place or premises where a related activity is authorized or conducted or in respect of which a licence or other authorization is issued or required under this Act; and (k) require to shown or produced and examine any fish, fish product, fish processing device or equipment, or other thing used in fish processing or for or in connection with a related activity or such other activity for which a licence is issued or required under this Act.

Viet Nam, Law on Fisheries No. 18/2017/QH14 of 2017

Article 61. Confirmation and certification of origins of aquatic products derived from commercial fishing activities. 1. Vietnamese competent authorities shall certify that materials and aquatic products are not derived from illegal commercial fishing activities within the Viet Nam's maritime boundary at the requests of organizations and individuals. 2. Competent authorities of the exporting country shall certify that imported aquatic materials are not derived from illegal commercial fishing activities at the requests of importers. 3. Aquatic products derived from imported aquatic materials shall be certified by Vietnamese competent authorities at the request of exporters if these materials are certified to be derived from legal commercial fishing activities by the competent authority of the exporting country. 4. The Minister of Agriculture and Rural Development shall provide guidelines for contents of and procedures for confirming aquatic material and certifying aquatic products derived from commercial fishing activities; confirming that imported aquatic materials or aquatic products manufactured from imported aquatic materials are not derived from illegal commercial fishing. (...) Article 88. Duties and power of the Fisheries Resources Surveillance force. 1. The fisheries resources surveillance force shall: a) Patrol, inspect, control, investigate and take action against violations of laws, apply measures for preventing violations in accordance with regulations of law; g) Cooperate with other relevant authorities in fisheries resources surveillance.

The PSMA provides guidelines for the training of port inspectors in the context of the duty of parties to ensure port inspectors are properly trained (Article 17). Such training guidelines should be developed by reference to, or taking into account CITES. Both the national observer programme and inspection scheme should include the requirement for specific training at adequate levels. Such training should enable graduates to effectively perform their duties. The duties of observers and inspectors should include the collection of data relevant to ensuring compliance with CITES requirements, and in recognizing CITES-listed aquatic species that may be found on board vessels. 
These legislative options could be incorporated in the fisheries legislation in the form of provisions which:

a. ensure observer programmes provide for mechanisms of data-sharing with the FA, MA, SA, RFBs and any other relevant authority;

b. include the duty of the appointed observer to collect, record and report data including documents and records in electronic format as well as other CITES-related information related to export and import permits, re-export and IFS certificates, export quotas;

c. provide specific training to observers and inspectors about CITES, its requirements, implementation, and identification of CITES-listed species;

d. promote cooperation and coordination between authorized personnel within fisheries inspection schemes and any other relevant authority, including the CITES enforcement officer; and

e. ensure that authorized fisheries personnel have the power to inspect and collect and, where necessary and appropriate, retain any documentation including documents and records in an electronic format that is relevant for CITES implementation.

\subsection{Part V: Enforcement}

The guidance in relation to offences and penalties within the Model Law (Part 7) should be considered, taking into account the particularities of countries' legal systems and procedures. It is important that in implementing CITES through national fisheries legal frameworks, the relevant legislation provides for effective enforcement mechanisms. Offences and penalties should include confiscation and forfeiture of specimens, as this is considered an effective and strong sanction for non-compliance with CITES that also deters future contraventions. In Italy, for example, the Ministry of the Environment, which is the designated MA, has the competence to decide whether specimens are submitted to the court, held in safe custody or destroyed. ${ }^{16}$

International trade in CITES-listed aquatic species in violation of the requirements should be considered as an offence in fisheries legislation and the weighting of penalty should be determined by reference to the seriousness of the offence and whether it constitutes a repeated offence. The criteria for determining the degree of seriousness of an offence can be based, for example, on whether the species was taken without a permit where such a permit is required or taking a specimen from a closed area. This is similar to the nature of acts that are considered serious violations under the Agreement for the Implementation of the Provisions of the United Nations Convention on the Law of the Sea of 10 December 1982 Relating to the Conservation and management of Straddling Fish Stocks and Highly Migratory Fish stocks (UNFSA). ${ }^{17}$ Aggravating circumstances, such as trade in specimens of species included in species listed in Appendix I or high volumes of illegally traded specimens, should be defined and taken into account when drafting legislative provision for the applicable penalties. The offences

\footnotetext{
${ }^{16}$ This information was shared during the CITES Expert Workshop. See FAO, 2019b.

17 See paragraph 11 of Article 21 of the Agreement for the Implementation of the Provisions of the United Nations Convention on the Law of the Sea of 10 December 1982 Relating to the Conservation and management of Straddling Fish Stocks and Highly Migratory Fish stocks.
} 
should include violation of CITES, the CITES-legislation and related requirements, as well as the violation of international fisheries conservation and management measures. These may include RFB measures that a country must enforce as a member of the RFB. Such provisions may enable a country as a member of an RFB, to act against violations in respect of the conservation of aquatic species, including CITES-listed species, even if that country is not a party to CITES. Penalty options should be broad, varying from the confiscation of specimens, fishing gear and vessels, to mandatory imprisonment as well as asset forfeiture in applicable cases. A broad range of possible penalties will allow the prosecutor and magistrate to determine the most appropriate penalty to be imposed in a particular case. In this respect, it is fundamental for the country to ensure that CITES and its relevant requirements are known by those prosecutors and magistrates so that they are capable of applying the right judgement and appropriate penalty.

Examples

Offences / Penalties

Liberia, Fisheries and Aquaculture Management and Development Law of 2019

Section 7.5. Illegal possession and trade in fish or fish products prohibited. (1) No person shall, or shall attempt to possess, import, export, transport, sell, receive, acquire, or buy any fish or fish products taken, possessed, transported, or sold in violation of this Act or any: (a) other law or instrument having the force of law in the Republic of Liberia; or (b) international agreement to which the Republic of Liberia is party. (2) Any person who contravenes Subsection (1) commits an offence and upon conviction shall be liable for a fine not exceeding the maximum amount described in the Second Schedule or a term of imprisonment not exceeding five years or both and the fishing vessel and gear used in the offence and all fish on board shall be forfeited and the gear shall be destroyed.

Madagascar, Law No. 2015-053 on the Fisheries and Aquaculture of 2015

Chapter IV - Regulation and Preservation. Article 18. Protected species. It is prohibited, at all times and places, in accordance with the national legislation in force and international conventions ratified by the Malagasy State, the fisheries, capture, detention and commercialisation of all endangered and protected species, corals, marine mammals, seabirds, marine turtles, and/or freshwater and aquatic organisms included in a list established by regulation and that which are object of conservation measures.

Mozambique, Fishing Law No. 22 of 2013

Article 88. Weighting of penalties. The establishment of the amount of applicable fine shall take into account the (a) type of fishing practiced and the local or zone where the penalty occurred, (b) the technical characteristics of vessel used in the commitment of the penalty, (c) the technical characteristics and the dimension of installations and processing or aquaculture establishments where the penalty occurred, $(d)$ the estimated economic benefit that the offender may have taken or took from the offence, (e) eventual damages caused to the public health, environment and ecosystems, (f) other relevant factors that the instructor may be aware of in the exercise of his functions.

Philippines, Republic Act No. 8550 of 1998 on the Fisheries Code, as amended in 2014

Section 102. (a) It shall be unlawful to fish or take, catch, gather, sell, purchase, possess, transport, export, forward or ship out aquatic species listed in Appendix I of the CITES, or those categorized by the IUCN as threatened and determined by the Department as such. Upon a summary finding of administrative liability, the Department shall penalize the offender with a fine equivalent to five times (5) times the value of the species or Five hundred thousand pesos $(P 500,000.00)$ to Five million pesos (P5,000,000.00), whichever is higher, and forfeiture of the species. (...) (b) It shall be unlawful to fish, take, catch, gather, sell, purchase, possess, transport, export, forward or ship out aquatic species listed in CITES Appendices II and III if scientific assessments show that population of the species in the wild cannot remain viable under pressure of collection and trade: Provided, That the taking or fishing of these species from the wild for scientific research, or conservation breeding simultaneous with commercial breeding may be allowed. Upon a summary finding of administrative liability, the Department shall penalize the offender with a fine equivalent to three (3) times the value of the species or Three hundred thousand pesos $(\mathrm{P300,000.00)}$ to Three million pesos $(\mathrm{P} 3,000,000.00)$, whichever is higher, and forfeiture of the species. (...) 
With respect to administrative and judicial processes, special enforcement proceedings could be established to deal with CITES cases and provide an offender with options for expediency and an effective settlement between the offender and the prosecution. Such proceedings include, for example, a Deferred Prosecution Agreement as applied in certain countries. ${ }^{18}$ Procedures should be set out clearly and should prompt the FA, MA or SA concerned to evaluate whether a petition by the alleged offender should be subject to the alternative enforcement process. Where the offence is considered as not serious, the legislation should provide for the possibility of compounding of offences.

These legislative options could be incorporated in fisheries legislation through provisions which:

a. treat the trade of CITES-listed aquatic species in violation of CITES and implementing legislation as an offence;

b. outline applicable penalties, and define aggravating circumstances such as the illegal trade of Appendix I listed species;

c. provide a broad range of penalty options and enforcement procedures, including treating and imposing higher penalties for serious violations and for the compounding of minor offences;

d. establish the possibility of special legal proceedings in certain predetermined circumstances in which the alleged offender can choose to be subjected to expedient disposition;

e. establish legal proceedings which permit the FA, MA or SA to consider the petition by the alleged offender asking to be subjected to alternative enforcement processes in respect of illegal trade of aquatic species listed in the CITES Appendices in certain predetermined circumstances; and

f. allow for the FA, MA and SA to appropriately deal with such cases.

\subsection{Part Vl: Regulations}

The primary legislation on fisheries should not provide specific details on matters that may be subject to periodic change or more sensitive matters requiring to be tailored to specific or local contexts. The general fisheries legal framework should leave these detailed requirements to secondary fisheries legislation such as regulations, administrative orders or public notices issued by the competent Ministry or other appropriate executive arm of government empowered to promulgate such enactments. The primary fisheries legislation should clearly designate the authority responsible for promulgating such secondary rules. The range of matters should ensure that such delegated mandate explicitly covers CITES-specific issues or is sufficiently wide to cover them. Notably, it should include a regulation which automatically updates the list of CITES Appendices pursuant to the latest CoP.

\footnotetext{
${ }^{18}$ As in the United Kingdom of Great Britain and Northern Ireland and the United States of America. This information was obtained during the CITES Expert Workshop and follow-up activities.
} 
Examples

Miscellaneous

Samoa, Fisheries Management Act No. 8 of 2016

Section 47. Regulations for processing, trading and marketing of fish and fish products (1) The Head of State may, acting on the advice of Cabinet, make regulations to give effect to or for the purposes of this Part, and in particular may make the following regulations: (a) regulating licensing or registration of persons or premises to process, trade and market fish and fish products, including conditions of any licence or registration; (b) prescribing requirements, standards and procedures for processing, trading and marketing of fish and fish products; (c) prescribing procedures, mechanisms and arrangements for the management, regulation and control of the processing, trading and marketing of fish and fish products; (d) providing the classes of fish and fish products; (e) regulating fish and fish products intended for use or consumption in Samoa or for export, including regulating domestic or export markets; (f) subject to the approval of the National Revenue Board, prescribing fees, charges and levies for the purposes of this Part; (g) regulating enforcement powers for the purposes of this Part, including entry, search, arrest, seizure, confiscation for the purposes of this Part; (2) Regulations under this section may have extra-territorial application.

Vanuatu, Fisheries Act No. 10 of 2014

Section 63. Giving effect to international conservation and management measures (1) The Minister may by notice, publish a list of the global, regional or sub- regional organisations or arrangements to which Vanuatu is a party or a cooperating non-contracting party. (2) The Minister may by notice, publish the international conservation and management measures which are to have the force of law in Vanuatu and on all fishing, vessels registered in Vanuatu wherever they are operating. (3) The Minister may specify in the notice under subsection (2), the parts of an international conservation and management measure that are to have the force of law in Vanuatu. (4) The Minister may, for the purpose of giving effect to any treaty entered into by Vanuatu or any international conservation and management measure or arrangement to which Vanuatu is a party or is a cooperating non-contracting party, make such regulations or give notice in the Gazette or attach such conditions to a licence as the Minister may consider necessary or expedient for this purpose. (5) The Minister may publish in the Gazette no less than every 6 months, any conditions that have been imposed on individual licences according to this section.

There should be a requirement in the fisheries legislation for the competent authority to periodically review the list of aquatic species included in the CITES Appendices, which may be part of a Schedule attached to the fisheries enactment. This should be carried out after every CITES COP to ensure the legislation is updated in a timely manner.

These legislative options could be incorporated in fisheries legislation through provisions which:

a. clearly define the authority with the power to enact secondary legislation or to issue orders or notices on any matters concerning CITES implementation; and

b. designate the power of the competent authority to update fisheries legislation and/ or regulations and/or schedules, where appropriate, to incorporate any amendments to the CITES Appendices. 
GUIDE

SUMMARY TABLE 


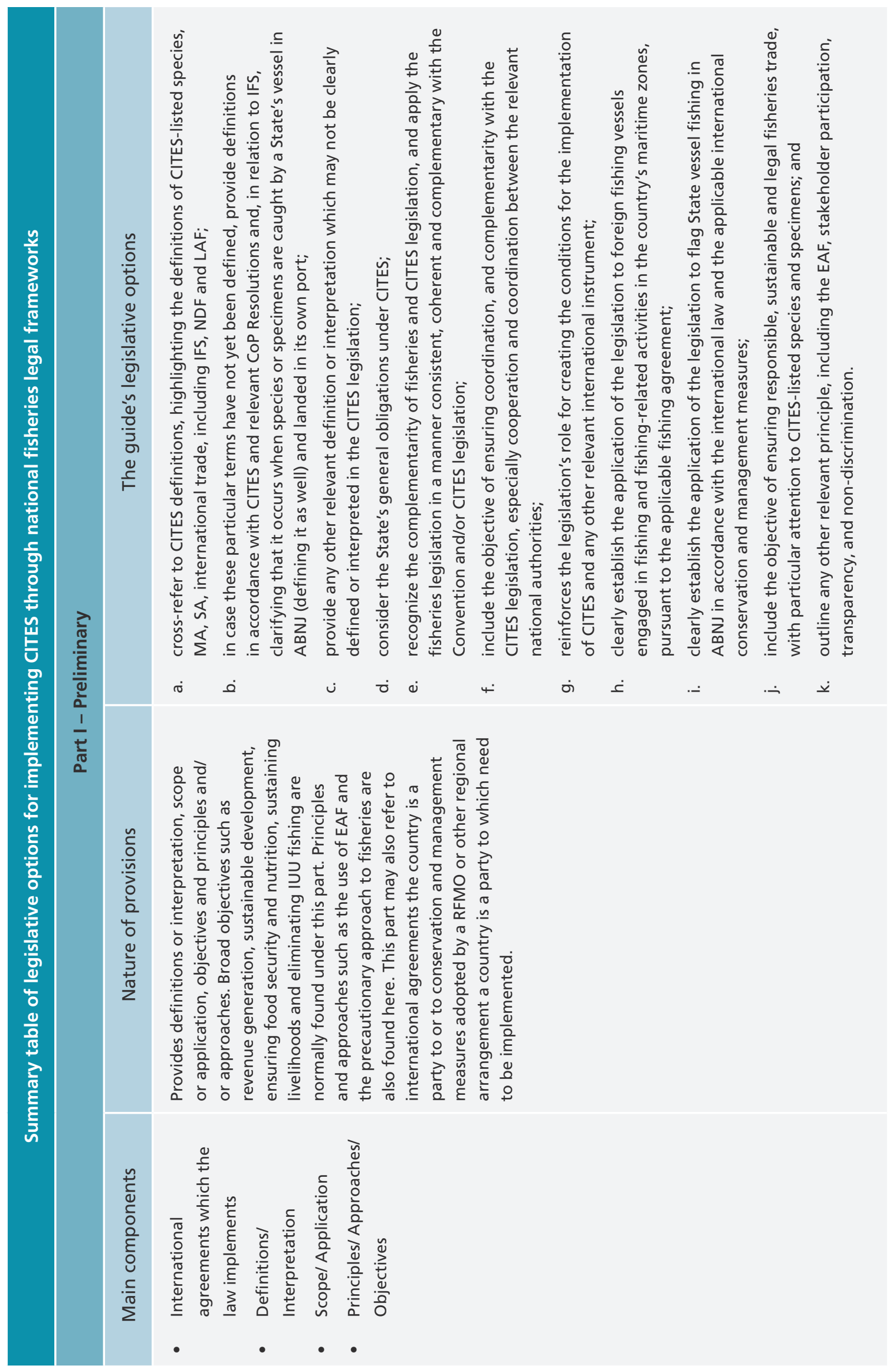




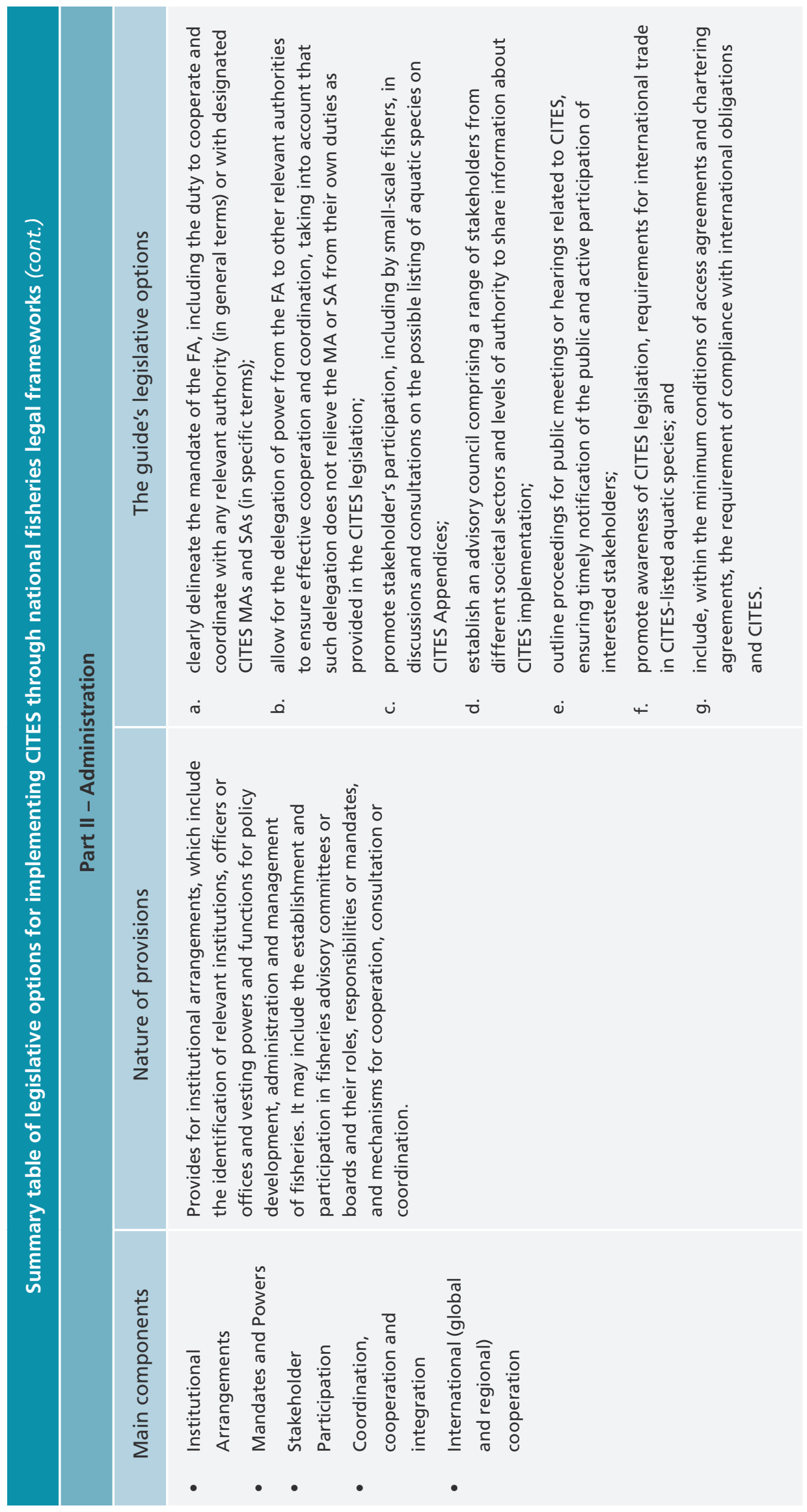




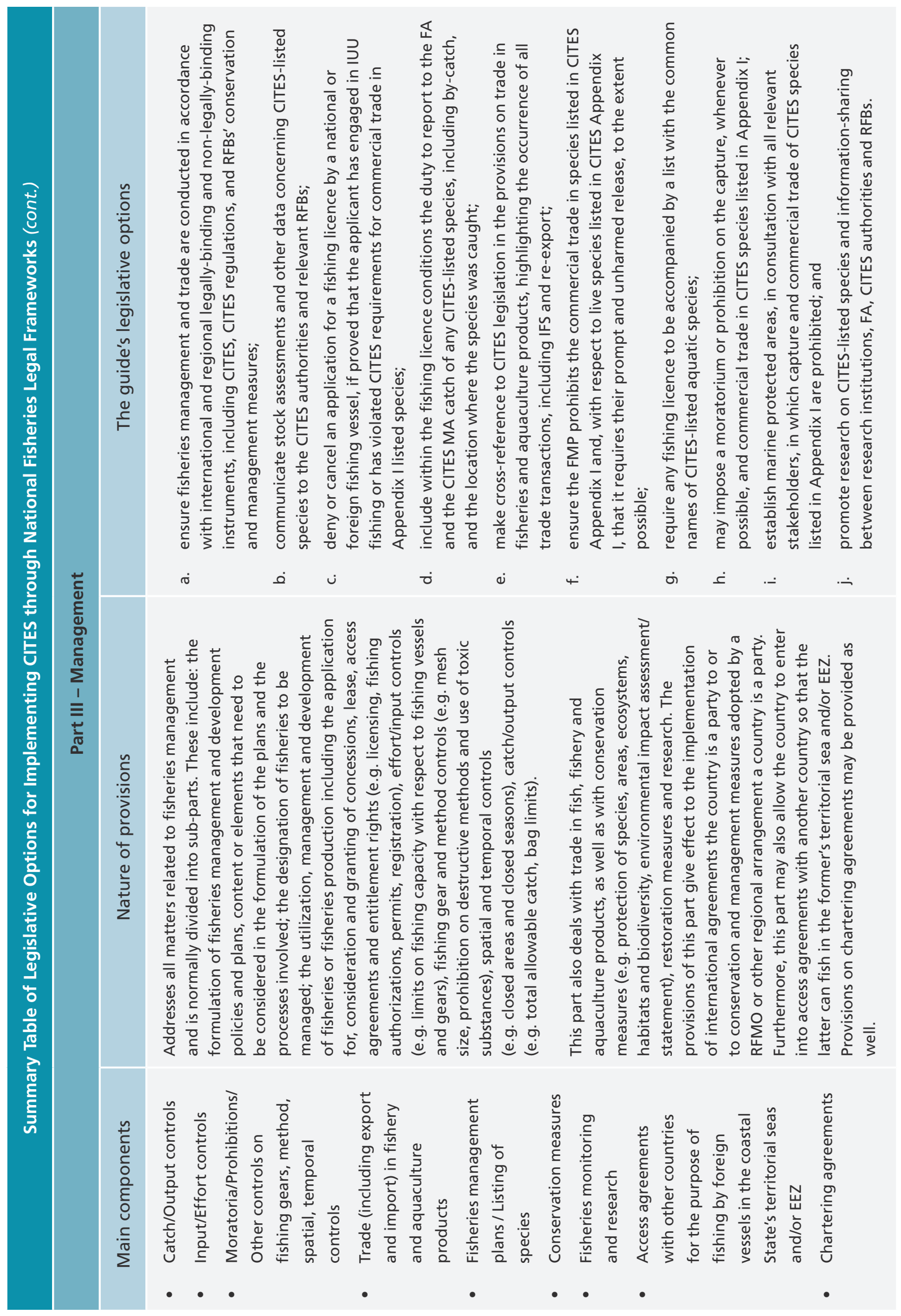




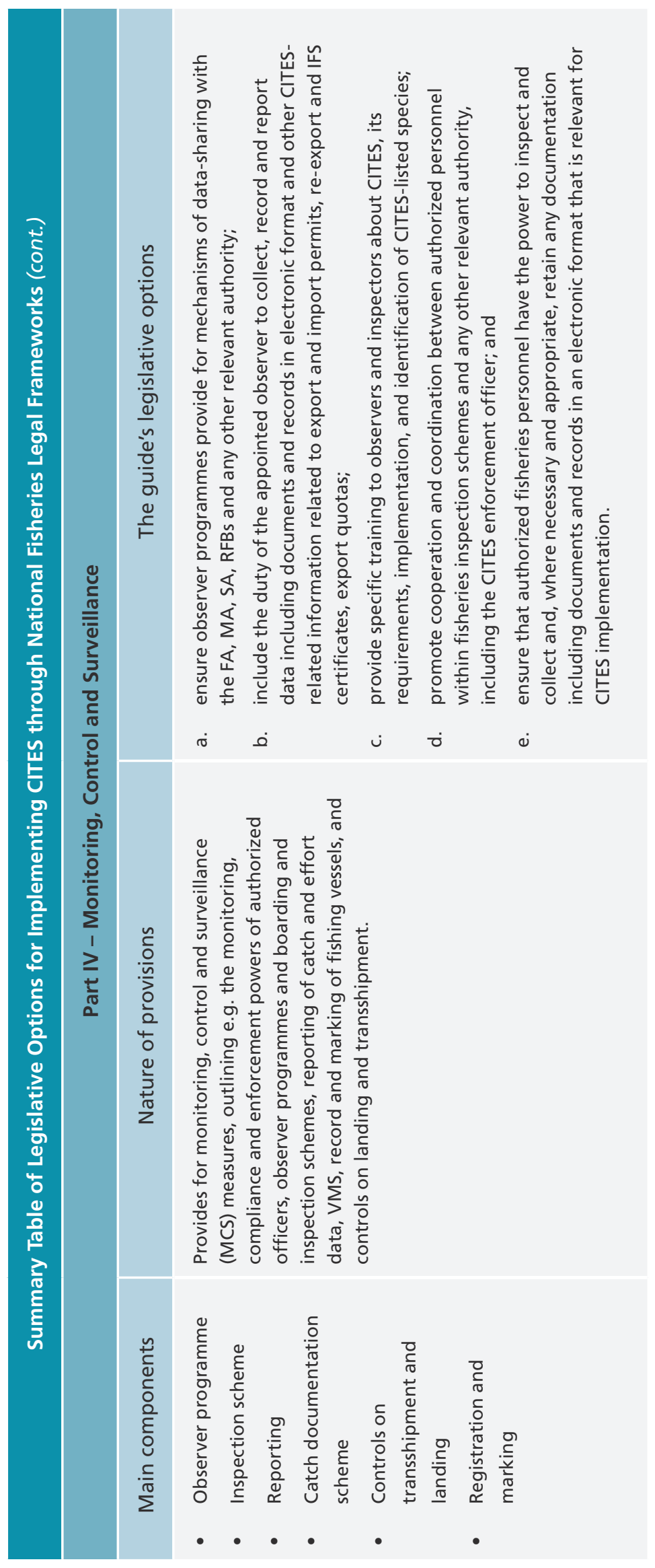




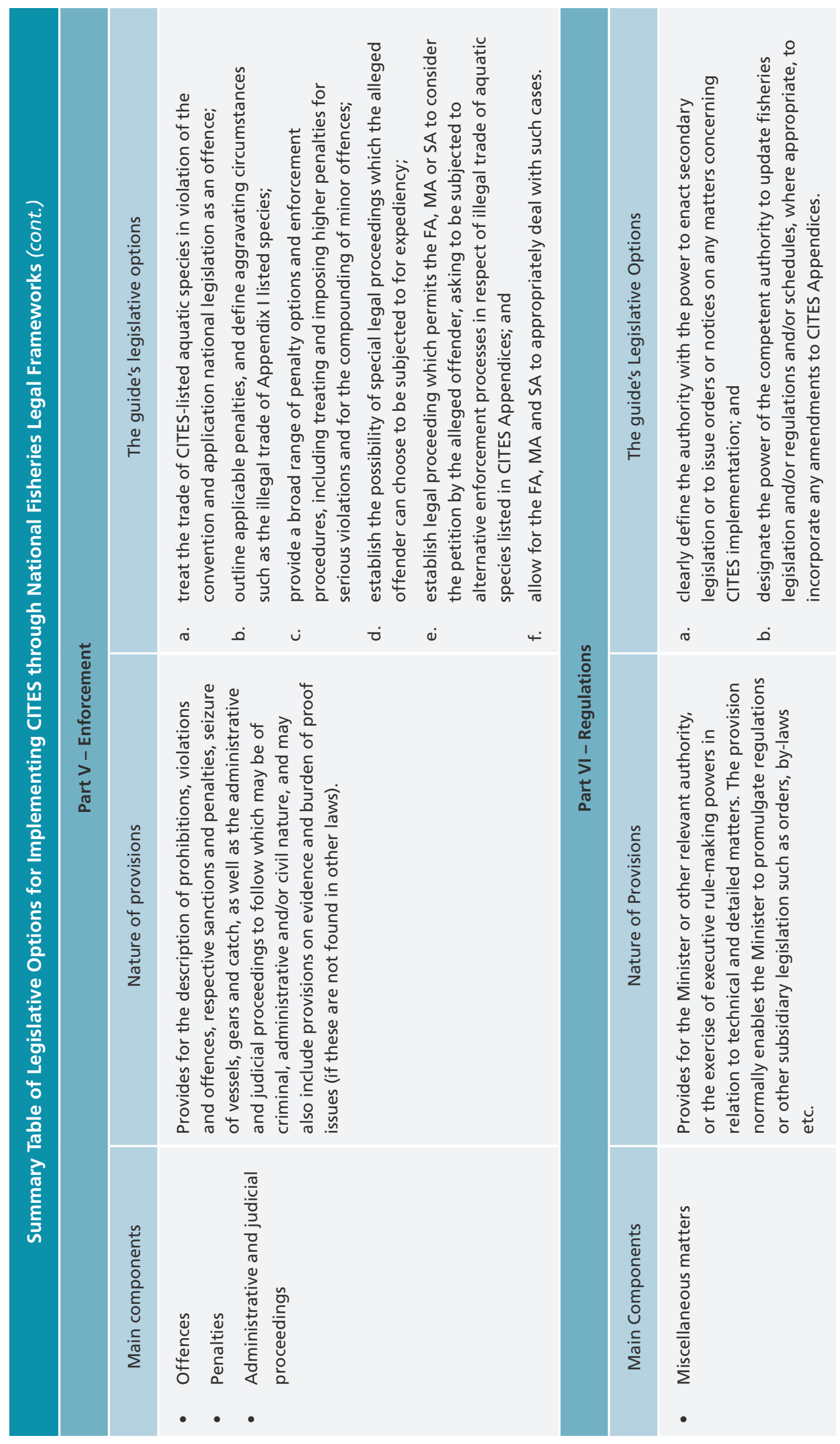




\section{References}

Literature

FAO. 2007. Legislative Drafting Guide: A Practitioner's View. Legal Papers Online No. 64. Rome. (also available at http://www.fao.org/3/a-bb097e.pdf).

FAO. 2016. A How-to Guide on legislating for an ecosystem approach to fisheries. In FAO EAF-Nansen project report No. 27, Rome, FAO. 2016. 56p at 17. (also available at http://www.fao.org/3/a-i5966e.pdf).

FAO. 2019a. Step-wise Guide for the Implementation of International Legal and Policy Instruments related to Deep Sea Fisheries and Biodiversity Conservation in Areas Beyond National Jurisdiction. Rome. (also available at http://www.fao.org/3/ca5628en/ca5628en.pdf).

FAO. 2019b. Report of the First Expert Workshop for the Assessment of Proposalson Implementing the Convention on International Trade in Endangered Species of Wild Fauna and Flora (CITES) through Fisheries Legal Frameworks, Rome, Italy, 6-8 May 2019. FAO Fisheries and Aquaculture Report No. 1 276. Rome. (also available at http://www.fao.org/documents/card/en/c/ca6856en/).

FAO. 2019c. Legal Office. Development Law. Magazine Issue No. 1. 2019. [online]. Rome [Cited 16 September 2020]. http://www.fao.org/legal/development-law/magazine-1-2019/en/

De Klemm, C. 1993. Guidelines for Legislation to Implement CITES. IUCN, Gland, Switzerland and Cambridge, UK.

Kuemlangan, B. 2009. Legal Aspects, in: K.L. Cochrane and S.M. Garcia (Eds.) A Fishery Manager's Guidebook, John Wiley \& Sons Ltd., Chichester, UK. Chapter 5, pp. 105-134.

International legally-binding Instruments

CITES. 1973. Convention on International Trade in Endangered Species of Wild Fauna and Flora (CITES). Adopted in Washington on 3 March 1973, entry into force on 1 July 1975, 993 UNTS 243.

CITES. 1992. Resolution Conf. 8.4 (Rev. CoP15) National laws for implementation of the Convention. Adopted at CoP8, in Kyoto, Japan, 02-13 March 1992. Amended at 14th and 15th meetings of CoP.

LOSC. United Nations Convention on the Law of the Sea (LOSC). Adopted in Montego Bay on 10 December 1982, entry into force on 16 November 1994, 1883 UNTS 397.

PSMA. 2009. Agreement on Port State Measures Agreement to Prevent, Deter and Eliminate Illegal, Unreported and Unregulated Fishing (PSMA). Adopted on 22 November 2009, entry into force on 5 June 2016, Rome.

UNFSA. 1995. Agreement for the Implementation of the Provisions of the United Nations Convention on the Law of the Sea of 10 December 1982 relating to the Conservation and Management of Straddling Fish Stocks and Highly Migratory Fish Stocks (UNFSA). Adopted in New York on 4 August 1995, entry into force on 11 December 2001, 2167 UNTS 3. 
National legislation

Angola. Aquatic Biological Resources Law No. 6-A/04 of 2004, as amended in 2005

Angola. Presidential Decree No. 311/18 approving the Regulation on the Import and Re-export of Wild Fauna and Flora Endangered Species of 2018

Australia. Fisheries Management Act of 1991

Bahamas. Wildlife Conservation and Trade Act of 2004 (Cap. 250A)

Brazil. Law No. 11959 of 2009

Cabo Verde. Legislative Decree No. 02 of 2020 approving the general regime regulating fishing activities in national maritime waters and the high seas

Cambodia. Royal Kram NS/RKM/0506/011 on Promulgation of the Fisheries Law of 2006

Chile. Law No. 20962 of 2016 applying CITES

Cook Islands. Marine Resources (Shark Conservation) Regulations of 2012

Costa Rica. Decree No. 41 056-MINAW of 2018 on Golfo Dulce Natural Sanctuary of Hammerhead Shark

Ecuador. Accord No. 204 of 2016

Eritrea. Fishery Products Importation and Exportation Regulations 2003 L.N. No. 69 of 2003

Estonia. Fishing Act of 2015

Fiji. Endangered and Protected Species Act No. 29 of 2002

Fiji. Fisheries (Amendment) Regulations L.N. No. 78 of 2004

Fiji. Offshore Fisheries Management Decree No. 78 of 2012

The Gambia. Fisheries Act No. 20 of 2007

Ghana. Fisheries Act No. 625 of 2002

Guinea. Law No. 2015/26/AN of 14 September 2015 on the Maritime Fisheries Code

Guyana. Regulations No. 3 of 1966 on Fisheries (Aquatic Wild Life Control)

Honduras. Accord No. 22 of 2019

Honduras. Accord No. 735 of 2008

Iran (Islamic Republic of). Law of 1967 on Hunting and Fishing, and Regulation of 1968 on Hunting and Fishing and the Fish and Wildlife Service

Jamaica. Fisheries Act No. 18 of 2018 
Jamaica. Endangered Species (Protection, Conservation and Regulation of Trade) Act No. 36 of 2000

Kenya. Fisheries Management and Development Act No. 35 of 2016

Lesotho. Zero draft International Trade in Endangered Species of Wild Fauna and Flora Bill of 2019

Liberia. Fisheries and Aquaculture Management and Development Law of 2019

Madagascar. Law No. 2015-053 on the Fisheries and Aquaculture of 2015

Malaysia. International Trade in Endangered Species Act No. 686 of 2008

Malaysia. Fisheries (Control of Endangered Species of Fish) Regulations 1999

Mali. Fisheries and Aquaculture Management Law No. 2014-062 of 2014

Mauritius. Fisheries and Marine Resources (Import of Fish and Fish Products) (Amendment) Regulations GN No. 34 of 2016

Mexico. Fisheries Regulations of 1999, as amended in 2004

Mozambique. Fishing Law No. 22 of 2013

Mozambique. Decree No. 43 of 2003 on Marine Fisheries' Regulation (REPMAR)

New Zealand. Fisheries Act No. 88 of 1996

New Zealand. Trade in Endangered Species Order of 2017

Peru. Ministerial Resolution No. 306 of 2004

Philippines. Republic Act No. 8550 of 1998 of the Fisheries Code, as amended in 2014

Philippines. Republic Act No. 10654 of 2014, amending the Fisheries Code Republic Act No. 8550

Philippines. Fisheries Administrative Order No. 185 of 1992

Saint Kitts and Nevis. Fisheries Aquaculture and Marine Resources Act No. 1 of 2016

Saint Kitts and Nevis. International Trade in Wild Fauna and Flora Act No. 41 of 2009

Samoa. Fisheries Management Act of 2016 and Marine Wildlife Protection Regulations of 2009

Samoa. Marine Wildlife Protection Regulations S.R. 2009/18 of 2009

Solomon Islands. Fisheries Management Act No. 2 of 2015

Solomon Islands. Wildlife Protection and Management (Amendment) Act No. 5 of 2017

South Africa. Marine Living Resources Act No. 18 of 1998 
Thailand. Royal Ordinance on Fisheries, B.E. 2558 of 2015

Tonga. Fisheries Management Act No. 26 of 2002

United States of America. Interagency cooperation - Endangered Species Act of 1973, as amended (50 CFR 402.01-402.48)

United States of America. Regulations of 1974 governing the taking and importing of marine mammals - Subpart D, Special Exceptions (50 CFR, 216.30-47)

Vanuatu. Fisheries Act No. 10 of 2014

Viet Nam. Law on Fisheries No. 18/2017/QH14 of 2017

\section{Technical documents}

CITES. 2018. National Laws for Implementation of the Convention: Report of the Secretariat. SC70 Doc. 25, 70th Meeting of the Standing Committee (Rosa Khutor, Sochi, Russian Federation, 1-5 October 2018).

CITES. 2019a. National Laws for Implementation of the Convention: Report of the Secretariat. CoP18 Doc. 26(Rev.1), 18th Meeting of the Conference of the Parties (Geneva, Switzerland, 16 August 2019).

CITES. 2019b. Interpretation and implementation matters: Regulation of Trade. Guidance for Making Legal Acquisition Findings. CoP18 Doc. 39, 18th Meeting of the Conference of the Parties (Colombo, Sri Lanka, 23 May - 3 June 2019).

\section{Electronic sources}

CITES. 2019c. Status of Legislative Progress in implementing CITES, as of November 2019 [online]. [Cited 16 September 2020]. https://cites.org/sites/default/files/projects/NLP/Legislative $\% 20$ status $\% 20$ table $\% 20$ November $\% 202019 \% 20$ for $\% 20$ web.docx

CITES. n.d-a. Biennial reports and Implementation Reports [online]. [Cited 16 September 2020]. https://cites.org/eng/resources/reports/Implementation_report

CITES. n.d-b. Legislative guidance materials. In: Implementation [online]. [Cited 16 September 2020]. https://cites.org/legislation/Legislative_guidance_materials

CITES. n.d-c. Model Law on International Trade in Wild Fauna and Flora. CITES Secretariat. In: National legislation [online]. [Cited 16 September 2020]. https://cites.org/sites/default/files/eng/prog/Legislation/E-Model\%20law-updated-clean.pdf

CITES. n.d-d. National Legislation Project. In: National legislation [online]. [Cited 16 September 2020]. https://cites.org/eng/legislation/National_Legislation_Project

ECOLEX. 2020. Results for legislation related to CITES. [online]. [16 September 2020]. https:// www.ecolex.org/details/convention-on-international-trade-in-endangered-species-of-wildfaunaand-flora-tre-000483/legislation/?q=cites\&type=treaty\&xdate_min=\&xdate_max= 
FAO. 2020. FAOLEX. [online]. Rome. [Cited 16 September 2020]. http://www.fao.org/faolex/en/ FAO. n.d. Legal Services for Development. In: FAO [online]. [Cited 16 September 2020]. http:// www.fao.org/legal-services/en/ 
Implementing the Convention on International Trade in Endangered Species of Wild Fauna and Flora (CITES) through national fisheries legal frameworks: a study and a guide

The listing of certain aquatic species in Appendix II of the Convention on International Trade in Endangered Species of Wild Fauna and Flora (CITES) has attracted attention and interest from fisheries administrations of States on the impacts such listing would have on the management of relevant fisheries. This sourcebook - consisting of a study and a guide - raises awareness of CITES, contributes to the comprehension of the CITES regime and its relationship with the fisheries sector, and provides guidance on the options and approaches to strengthen CITES implementation through national fisheries legal frameworks.

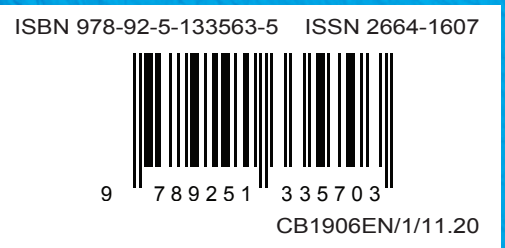

